GÖTTINGER ZENTRUM

FÜR BIODIVERSITÄTSFORSCHUNG UND ÖKOLOGIE

- Göttingen Centre for Biodiversity ANd Ecology -

\title{
THE INFLUENCE OF LAND-USE INTENSIFICATION AND BIODIVERSITY ON GRASSLAND BIOMASS, WATER USE AND PLANT FUNCTIONAL TRAITS
}

\author{
Dissertation zur Erlangung des Doktorgrades der \\ Mathematisch-Naturwissenschaftlichen Fakultäten der \\ Georg-August-Universität Göttingen
}

vorgelegt von
Laura Rose

aus

Tübingen

Göttingen, März 2011 
Referent:

Korreferent:

Tag der mündlichen Prüfung:
Prof. Dr. Christoph Leuschner

Prof. Dr. Johannes Isselstein

04.05.2011 
'The average gives the world its durability. The unusual its value.' attributed to Oscar Wilde 


\section{Table of contents}

\section{CHAPTER 1}

Introduction

\section{CHAPTER 2}

Effects of different livestock types on biomass and nitrogen partitioning in temperate pastures with different functional group abundances

Laura Rose, Dietrich Hertel, Christoph Leuschner

\section{CHAPTER 3}

The diversity-productivity relationship in permanent grasslands: negative diversity effect, dominant influence of management regime Laura Rose, Christoph Leuschner

\section{CHAPTER 4}

Effects of fertilization and cutting frequency on the water balance of a temperate grassland Laura Rose, Heinz Coners, Christoph Leuschner

\section{CHAPTER 5}

Management alters interspecific leaf trait relationships and trait-based species rankings in permanent meadows

Laura Rose, Marie Carolin Vogel, Dietrich Hertel, Christoph Leuschner

\section{CHAPTER 6}

Synthesis

\section{CHAPTER 7}

Summary

\section{CHAPTER 8}

Appendix 


\section{Abbreviations used}

AGB Aboveground biomass

A $_{\max } \quad$ Photosynthetic capacity at light saturation

ANPP Aboveground net primary production

BGB Belowground biomass

DRR Deep root ratio

ET Evapotranspiration

FRB Fine root biomass

I Infiltration

IN Precipitation interception

$\mathbf{N}_{\text {area }} \quad$ Area-based leaf nitrogen concentration

$\mathbf{N}_{\text {mass }} \quad$ Mass-based leaf nitrogen concentration

RAI Root area index

$\mathbf{R}: \mathbf{R} \quad$ Root per shoot biomass ratio

SLA Specific leaf area

VPD Air vapor pressure deficit

WUE Water use efficiency 

CHAPTER 1

Introduction 


\subsection{Biodiversity and ecosystem functioning}

In the Origin of Species Darwin (1859) wrote: 'It has been experimentally proved, that if a plot of ground be sown with one species of grass, and a similar plot sown with several distinct genera of grasses, a greater number and greater weight of dry herbage can be raised in the latter than in the former case.' Since this time numerous studies focused on the impact of species richness on biomass production and other ecosystem services and functions in a wide variety of ecosystems (Hooper et al. 2005). The recent motivation for research on the importance of species richness for ecosystem functioning is concern about the consequences of an alarming rate of species extinctions (Vitousek 1994, Vitousek et al. 1997, Sala et al. 2000, Barnosky et al. 2011).

Species differ in traits which influence their performance in different environments (e.g., Mc Intyre et al. 1999, Wright et al. 2004). Vice versa, the species-specific characteristics influence the physical and biological environment (Hooper 1998, Díaz et al. 2004). Thus, Chapin et al. (1997) hypothesize that changes in species composition alter the functioning of ecosystems. Hector and Bagchi (2007) show that an increasing number of species with different functional traits has the potential to positively influence the number of ecosystem functions. Complementary resource use of species differing in their ecological niches often explains positive biodiversity effects on ecosystem functioning (Hector et al. 1999, van Peer et al. 2004, Roscher et al. 2005, Kahmen et al. 2006).

On the other hand, decreased species richness increases the vulnerability of grassland ecosystems to drought (Tilman \& Downing 1994), decreases the carbon source strength (Fornara \& Tilman 2008) and increases nitrogen leaching (Tilman et al. 1996, Hooper \& Vitousek 1998, Scherer-Lorenzen et al. 2003). Concerning habitat quality, species-poor grasslands offer fewer niches for hemiparasites, invertebrates and vertebrates (Joshi et al. 2000, Spehn et al. 2000, Vandenberghe et al. 2009).

For humanity, aboveground biomass production is one of the most important functions of grassland ecosystems. However, whether this service is deteriorated by species losses in natural or semi-natural grassland ecosystems remains uncertain (Smith \& Knapp 2003). 


\subsection{Threats for Central European grassland diversity}

For centuries, managed grasslands belonged to the most species-rich plant communities of Central Europe, harbouring about 1000 higher plant species, roughly one-third of the indigenous flora (Ellenberg \& Leuschner 2010). In large areas of central Europe, grassland management shifted from extensive grazing and mowing regimes with one cutting per year to highly intensive pastures and meadows with three to six cuttings since the 1960s or 1970s. Fertilization has been increased to amounts of $150-300 \mathrm{~kg}$ nitrogen fertilizer ha ${ }^{-1}$ instead of no or minimal fertilization in the past and non-profitable sites mostly on low productive soils became abandoned (e.g., Vitousek et al. 1997, Sala et al. 2000, Krahulec et al. 2001, Tasser \& Tappeiner 2002).

Abandonment often causes a decline in species diversity (Maurer et al. 2006) and can result in succession to woody vegetation (Hansson \& Fogelfors 2000). The intensification of management, on the other hand, results in a progressive change of plant species composition from grasses and herbs with low to moderate $\mathrm{N}$ demand to grassland species with elevated assimilation and growth rates under high N supply (e.g., Tilman 1987, Poorter \& De Jong 1999, Grime 2002, Wesche et al. 2009, and references therein) and species more tolerant to frequent disturbance (Díaz et al. 1992, Craine et al. 2001). In addition to this shift in species composition in temperate grasslands $\mathrm{N}$ fertilization has been shown to cause a significant reduction in species richness (e.g., Wilson \& Shay 1990, Jacquemyn et al. 2003, Maurer et al. 2006, Klimek et al. 2007, 2008). An over-regional survey by Gough et al. (2000) revealed that increased fertilization by $90-130 \mathrm{~kg} \mathrm{~N}^{-1}$ increases productivity by $50 \%$ but decreases species richness by alarming $30 \%$. Moreover, large-scale vegetation surveys indicate that mesic and wet grasslands in northern Central Europe lost $30-50 \%$ of its plant species richness since the 1950/60s with median plant diversity per plot being reduced from about 25 - 30 species to 15 - 20 or less due to land-use changes (Wesche et al. 2009, Krause et al. 2011).

Significant losses in plant species diversity have been recorded in many grassland communities in the second half of the $20^{\text {th }}$ century, putting a number of specialist grassland species on the verge of extinction and rendering species-rich grassland a highly threatened habitat type (Sala et al. 2000, Kahmen et al. 2002). Since the demand for agricultural products is further increasing under a growing food and energy demand worldwide, agricultural intensification and consequentially species losses among temperate grasslands are likely to intensify within the next decades (Tilman et al. 2001). 


\subsection{Biodiversity studies in temperate grasslands}

The general decline in plant diversity in grassland communities has raised concern whether the dramatic impoverishment has negatively affected ecosystem functions and services in temperate grasslands (Tilman \& Downing 1994, Schmid et al. 2001, Hooper et al. 2005, and references therein). Knowledge about the functional consequences of biodiversity loss is important for defining goals for future agricultural policy in Europe and other industrialized countries, and for shaping conservation and restoration programs in managed temperate grasslands.

Results from four prominent experimental grassland biodiversity studies (Ecotron, Cedar Creek, Biodepth and the Jena experiment) with artificial assemblages of grassland species sown on sterilized soil showed productivity increases with increasing numbers of species present (Naeem et al. 1994, Tilman et al. 1997, Spehn et al. 2005, Marquard et al. 2009). These positive biodiversity effects may be explained by niche differentiation and biotic interactions leading to increased local resource use (Hector 2001, van Peer et al. 2004).

A second approach to investigate the impact of species richness on grassland productivity is the manipulation of species richness in permanent grasslands by the removal of certain species. These experiments in natural systems found production to be rather insensitive to decreases in diversity (Smith \& Knapp 2003, Suding et al. 2006).

In natural or semi-natural grasslands, the most productive communities are typically species-poor with dominance of a few N-demanding competitive grasses (e.g., Kahmen et al. 2002, Maurer et al. 2006, Wesche et al. 2009). Thus, most comparative studies in permanent grasslands found no diversity-productivity relationship or reported a hump-shaped curve with a marked diversity decrease at higher productivities (Silverton 1980, Oomes 1992, Thompson et al. 2005, Grace et al. 2007).

Several causes have been discussed for the minor relevance of results obtained from biodiversity experiments with artificial assemblages for natural communities. Firstly, the immaturity of the sown communities are a poor template of semi-natural grasslands with long continuity (e.g., Thompson et al. 2005). Secondly, the fact that the importance of niche complementarity may be reduced in species-richer stands by other biotic interactions such as competition (Yachi \& Loreau 2007). Finally, the artificial maintenance of dominance hierarchies by frequent weeding introduces a disturbance not found in 'real' grassland communities. Another often criticized reason for a positive correlation between productivity and species richness is the 'sampling effect'. It describes the increased probability to include 
high-productive species with increasing species richness in random species assemblages (Huston 1997, Wardle 1999, Huston et al. 2000). Many also argue that the discrepancies between the results obtained from artificial and semi-natural communities may partly be caused by different spatial scales considered (e.g., Oksanen 1996, Gough et al. 2000, Chase \& Leibold 2002, Gross et al. 2009). Most field studies in managed and natural grasslands investigated the diversity-productivity relationship in large plots (e.g., Oomes 1992, Kahmen et al. 2005, Grace et al. 2007) and considered stands with contrasting soil and/or climate conditions. Complementary resource use or facilitation and competition, however, should be more relevant at the small, plant-neighbourhood scale where plant individuals are directly interacting. In fact, Gross et al. (2009) could detect a positive diversity-productivity relationship only in small $0.2 \mathrm{~m}^{2}$ plots of semi-natural grasslands but not at larger scale ( $375 \mathrm{~m}^{2}$ plots). The biotope space (i.e. the available space for a plant community to explore) can also severely affect the strength of the biodiversity-productivity relationship because it can alter the opportunity for spatial niche separation and may therefore by a problem in biodiversity experiments where plants are grown in pots (Dimitrakopoulos \& Schmid 2004).

Most studies in permanent mature grasslands compared a range of grassland communities at different sites (e.g., Kahmen et al. 2005, Grace et al. 2007), and thus are not directly comparable to artificial grassland studies that compare communities of different species richness within one site. Species-richness gradients in theses studies are mostly determined by the recent or former management regime, and consequentially site productivity should rather be seen as a source variable determining species richness and not as a response to species richness (Tilman 1993). Furthermore, species losses in natural ecosystems do not occur randomly (Vitousek et al. 1997, Loreau et al. 2001, Grime 2002), but are directional in the way that rare and uncommon species are more likely to get extinct than dominant common species that determine community productivity (Whittaker 1965, MacArthur \& Wilson 1967, Grime 1998), which may be a reason for the stability of ecosystem functioning under non-random species loss (Smith \& Knapp 2003). At last, because fertilizer input mostly determines productivity of grasslands, the biodiversity-productivity relationship may well depend on nutrient availability (Kenkel et al. 2000, Dimitrakopoulos \& Schmid 2004). 


\subsection{Management effects on the structure and functioning of Central}

\section{European grasslands}

The two key factors of grassland management are (i) the amount of biomass removed by mowing or livestock grazing, and (ii) the amount of fertilizer applied at the site. Both factors severely alter the resource availability for plants. While the mowing or grazing regime determines the light availability and carbon and nutrient losses, fertilization determines nutrient availability.

Although both mowing and grazing remove aboveground biomass, cutting events lead to a uniform reduction of the biomass of the complete sward, while different types of livestock can influence the species composition of pastures differently (Armstrong et al. 1997). For example, sheep have a more selective grazing behavior than cattle and reduce the biomass of nitrogen-rich herbs and legumes to a greater extend (Ellis et al. 1976). Furthermore, sheep are able to remove biomass closer to the ground surface than cattle (Grant et al. 1985). Hence, the livestock type can have profound effects not only on the amount of biomass removed, but also on the nitrogen concentration of the residual biomass. However, grazing can also be an effective treatment to maintain grassland diversity counteracting the negative impact of nitrogen fertilization (Jacquemyn et al. 2003).

Despite its direct effect on aboveground biomass, defoliation can modify carbon allocation and root growth (Tomanek \& Albertson 1957, Richards 1984, Bonachela 1996, Liu \& Huang 2002, Patty et al. 2010, Rueda et al. 2010). It is generally assumed that repeated mowing and grazing cycles lead to a reduction of root biomass because assimilates are increasingly used for the regrowth of shoots (e.g., Speidel \& Weiß 1972, Gass \& Oertli 1980, Dawson et al. 2000). Fertilization, on the other hand, typically leads to a reduction of the root:shoot biomass ratio of grassland plants because of a stimulation of shoot growth leading to a higher aboveground biomass, while root growth and belowground biomass often change only little (e.g., Poorter et al. 1995, Reynolds \& D' Antonio 1996, Schippers et al. 1999). Thereby, land-use changes have the strong potential to alter the sward structure of temperate pastures and meadows not only due to changes in plant species composition, but also because of changes in the biomass allocation of existing plant communities in shorter time periods.

Additionally to its profound effects on the vegetation structure and the standing biomass stock, land-use changes have the potential to alter biogeochemical cycles (Greenwood et al. 1992, Rosset et al. 2001). It is well known that fertilized grasslands do not only have higher 
productivities, but also higher evapotranspiration rates than unfertilized ones (e.g., Wind 1954, Husemann \& Wesche 1964, Monteith 1988, Schulze et al. 1994). Evapotranspiration can be influenced by changes in biomass and litter production, leaf area index, or species composition (Monteith 1988, Greenwood et al. 1992, Schulze et al. 1994, Rosset et al. 2001, Polley et al. 2008, Verheyen et al. 2008). Hence, land-use changes have the potential to markedly alter the water balance of temperate meadows and pastures (Husemann \& Wesche 1964, Klapp 1971).

In addition to these potential alterations on the stand level, grassland management also strongly influences resource availability for single plant individuals. To optimize resource capture, plants can respond to alterations in resource availability by changes in functional traits like the specific leaf area or the leaf nitrogen concentration (e.g., Díaz et al. 1992, Anderson \& Briske 1995, Quétier et al. 2007). An increase in specific leaf area allows for a better light capture per unit carbon invested and a faster carbon accumulation and re-growth after disturbance (Garnier 1992, Wright \& Westoby 2002, Reich et al. 2003, Díaz et al. 2004, Wright et al. 2004). Consequently, this mechanism can be advantageous for species coping with a periodical loss of biomass (Caldwell et al. 1981, Díaz et al. 1992, Garnier et al. 1997, Díaz et al. 2004) and under low light availability (Ryser \& Eek 2000). Thus, we can expect functional trait alterations of grassland plants in response to different management intensities.

\subsection{General study aims}

This study was conducted within the framework of two interdisciplinary grassland projects. The BIOMIX project aims at disentangling the effects of functional group abundance and different types of livestock grazing on species composition, grassland yields, biomass nitrogen pools, and biomass allocation. The GrassMan project focuses on the role of plant diversity and land-use intensification for ecosystem functions like productivity, agricultural yield and ground water recharge. It also covers the fields of plant biomass partitioning, ecophysiological and morphological plant responses, plant-insect interactions, soil chemistry, plant pathogens and root herbivore, and trophic interactions of the invertebrate soil fauna.

Our study is subdivided into four studies, one at the BIOMIX site and three at the GrassMan site, focusing on different aspects of grassland functioning: 
i) first, we aim at disentangling the effects of different types of livestock grazing on pastures differing in the abundance of herbs and grasses. Our special focus lies on the effects of biomass removal on above- and belowground biomass and nitrogen allocation (BIOMIX project).

ii) The second approach aims at analyzing the effects of a herbicide-induced species richness gradient on above- and belowground biomass and biomass production. To get a more realistic view of biodiversity effects than studies in artificial grassland assemblages can provide, we conducted this study at an old-grown permanent grassland site (GrassMan site) under two cutting frequencies (one vs. three cuttings per season) and with two levels of fertilization (no fertilizer input vs. NPK-fertilization).

iii) Our third study we also conducted at the GrassMan site focusing on the effects of different land-use intensities on the water balance of temperate meadows. With 24 small weighable lysimeters, installed in fall 2008, we measured evapotranspiration and infiltration rates during the growing season 2009 in plots differing in cutting frequency and fertilization level (see ii).

iv) The last focus was on the responses of functional leaf traits of eight grassland species to different land-use regimes at the GrassMan site. To investigate the effects of land-use changes on leaf traits, and trait relationships and variation, we measured the specific leaf area of eight grassland species and related the values to mass- and area-based nitrogen concentrations. 


\subsection{Experimental sites}

Both experimental sites are located at the Solling Mountains, Lower Saxony, in Central Germany (Figure 1.1).

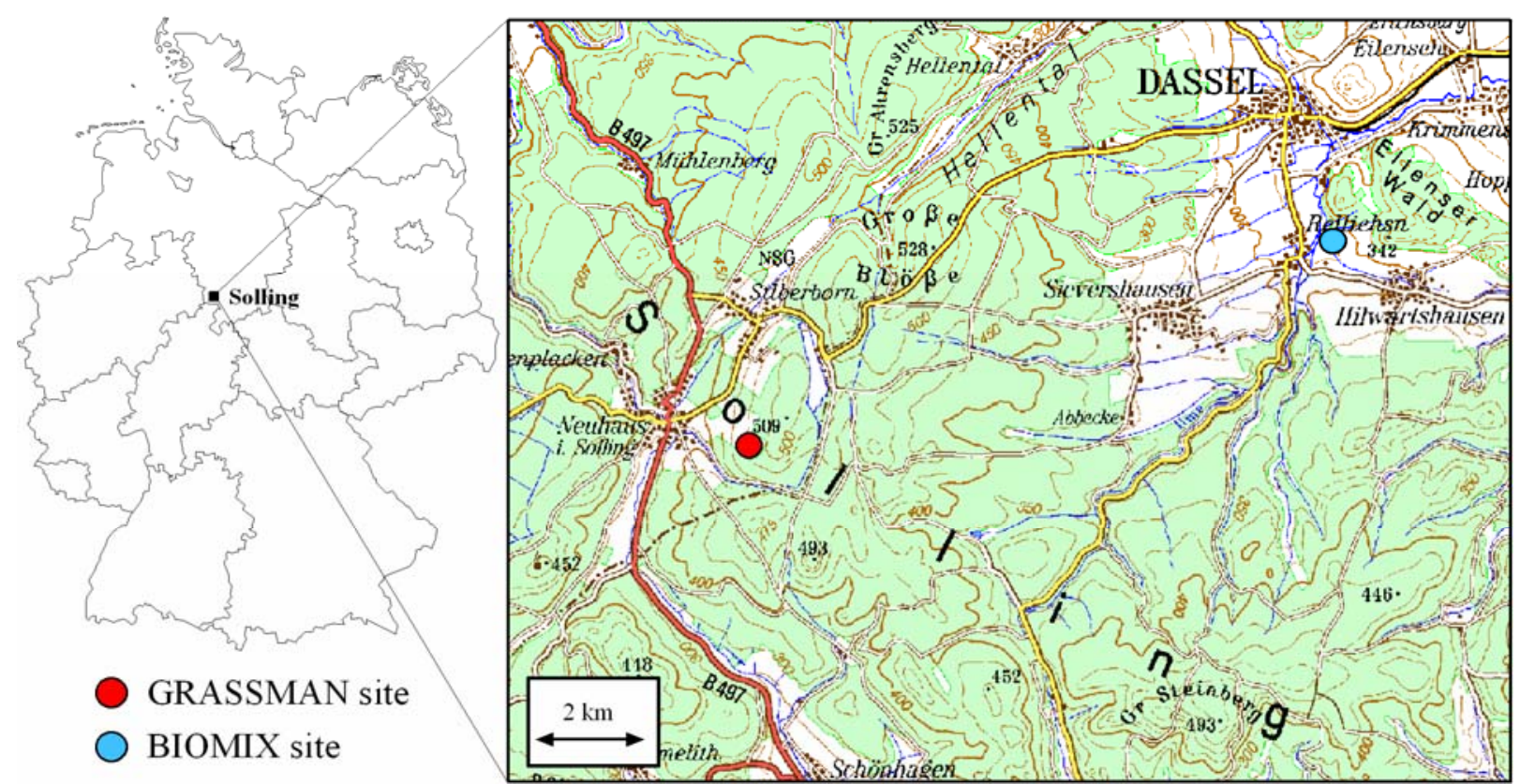

Figure 1.1: Location of the two experimental sites at the Solling Mountains, Central Germany.

\subsubsection{The BIOMIX project}

The BIOMIX project was established on pastures of the experimental farm Relliehausen at the foothills of the Solling Mountains, Central Germany (51\%/46` N, 9\%/41` E, $180 \mathrm{~m}$ a.s.1.). The mean annual precipitation is $879 \mathrm{~mm}$ and the mean annual temperature is $8.2^{\circ} \mathrm{C}(\mathrm{DWD}$, Dassel, 1961 - 1990). The soil type is a pelosol on Buntsandstein, the texture is a clayey/silty loam. The grassland community on the study plots represents a mesotrophic type of the LolioCynosuretum pasture association and the site has been used as a mown pasture for at least 15 years. Cattle manure has been regularly applied during that period (Seither et al. 2010).

The experimental design is a full-factorial block design including two functional group abundance levels and three livestock types leading to six different treatments (Figure 1.2). Eighteen 0.5 ha plots were installed in three blocks $(A, B, C)$ of each six pasture plots in 2006. Half of the plots were treated with the herbicides Starane and Duplosan KV (active components Fluroxypyr/ Triclopyr and Duplosan KV) to exclude legumes and non-legume herbs, thereby creating swards dominated by monocotyledonous species. Herbicide application took place on September 14, 2006, two years before sampling. 


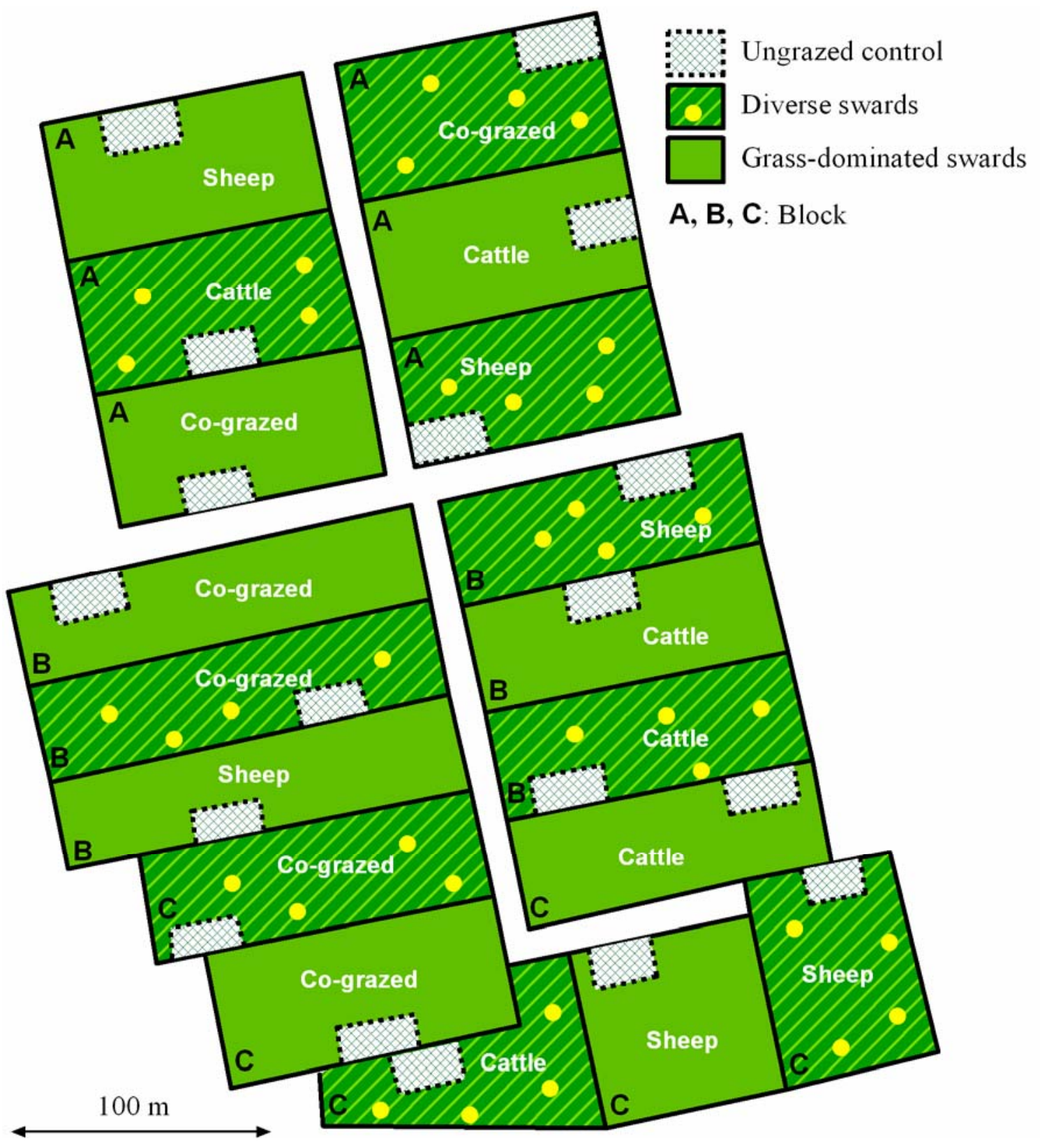

Figure 1.2: Experimental design of the BIOMIX project.

Grazing was conducted in a rotation system between the three blocks with cattle, sheep or co-grazing with cattle and sheep (2000 - $3000 \mathrm{~kg}$ animal live weight per plot (12 livestock units per ha)). A fenced area of $70 \mathrm{~m}^{2}$ was demarcated in each plot in 2008 to serve as ungrazed control.

\subsubsection{The GrassMan project}

In spring 2008, the GrassMan project was installed as a matrix of permanent meadow plots with different management regimes at the experimental farm Relliehausen, Solling 
Mountains, Central Germany (51 $44^{\prime} \mathrm{N}, 9^{\circ} 32^{\prime} \mathrm{E}, 490 \mathrm{~m}$ a.s.1.). Mean annual precipitation is $1031 \mathrm{~mm}$ and the mean annual temperature is $6.9^{\circ} \mathrm{C}$ (DWD, Silberborn, $\left.1961-1990\right)$. The experimental site is a slightly sloping (ca. $5^{\circ}$ ) grassland area of 4 ha size and soils are haplic Cambisols on Buntsandstein with a $\mathrm{pH}_{\mathrm{H}_{2} \mathrm{O}}$ between 5.2 and 5.6. The grassland community at the site can be classified as 'historically old' in the sense of Waesch (2003) and Ellenberg \& Leuschner (2010), because the continuity of the grassland can be traced back over more than 100 years (Preußische Landesaufnahme 1905): In previous decades, the site has been used for extensive cattle grazing and it is known to have been grazed at least since the late $18^{\text {th }}$ century. The most abundant grass, non-legume herb and legume species are Agrostis capillaris L., Rumex acetosa L. and Trifolium repens L., respectively, and the community has been classified as a Lolio-Cynosuretum association. The number of species in $9 \mathrm{~m}^{2}$ relevés ranged from 13 to 17 species (Petersen et al. 2010a). Thus, the grassland community is characterized as moderately species-rich, extensively used upland grassland of mesic soil moisture and fertility.

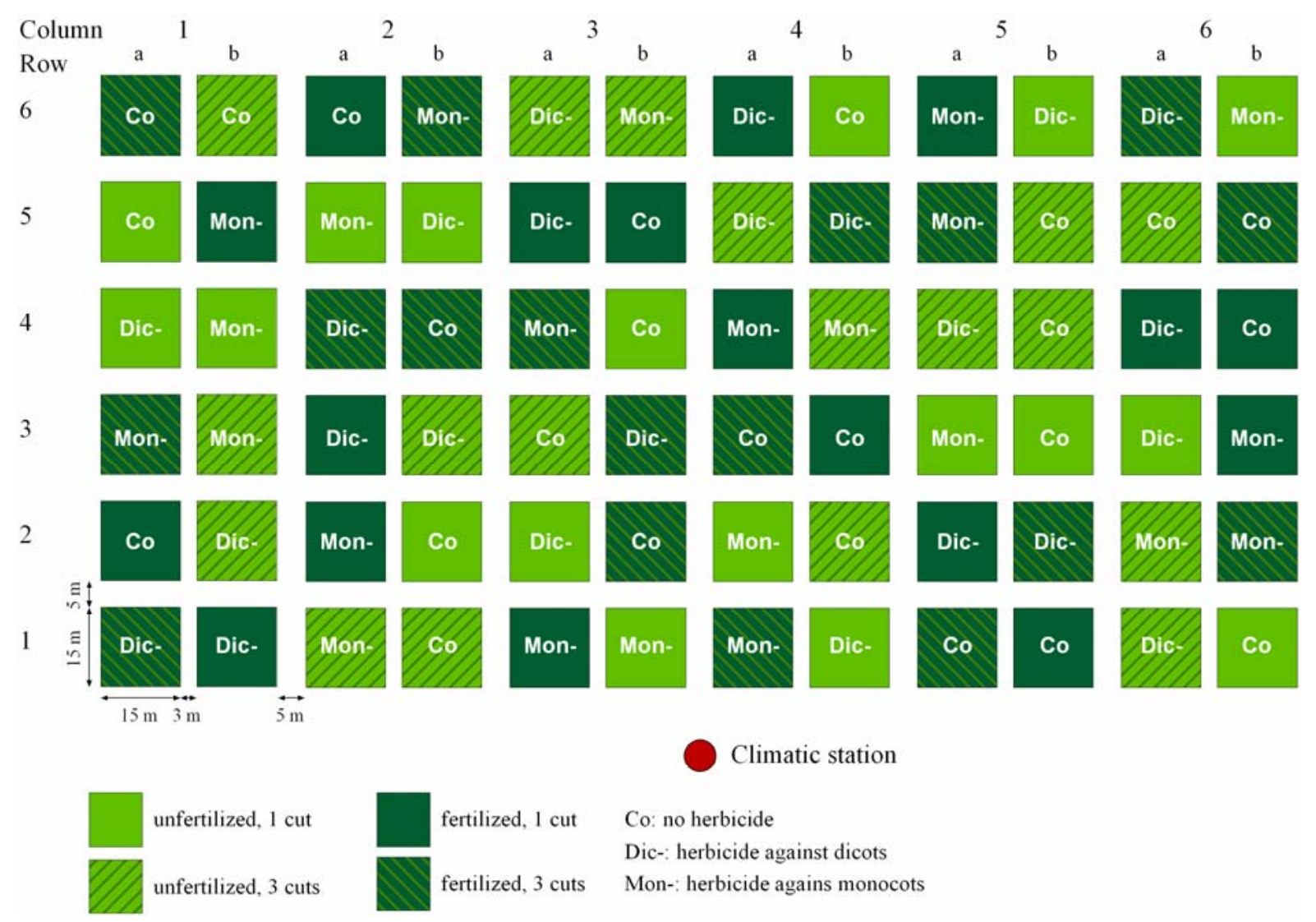

Figure 1.3: Experimental design of the GrassMan project. 
The full-factorial study-design includes two NPK-fertilization levels (no vs. NPKfertilization, 180-30-100 $\mathrm{kg} \mathrm{ha}^{-1} \mathrm{yr}^{-1}$ ) applied at meadows with one late cut in July or three cuttings per season (May, July, and September). As a third factor, plant diversity in the grassland plots was manipulated by selective herbicides against either monocots or dicots, resulting in three diversity levels: one third of the plots was treated with the herbicide Select 240 EC (Stähler Int., Stade, Germany; $0.5 \mathrm{~L} \mathrm{ha}^{-1}$ ) to decrease the abundance of monocots (Mon-), one third was treated with the herbicides Starane and Duplosan KV (active components Fluroxypyr/ Triclopyr and Duplosan $\mathrm{KV}$; both $3 \mathrm{~L} \mathrm{ha}^{-1}$ ) to decrease the amount of dicots (Dic-) and one third was left untreated as a control (Co). Herbicide application took place on July 31, 2008, and led to significant changes in functional group abundances and species richness by elimination of certain species without destroying the principal structure of the community (Petersen et al. 2010 a,b). The 12 different treatments were replicated six times resulting in 72 established plots of $15 \mathrm{~m} \times 15 \mathrm{~m}$ size arranged in a Latin square with $5 \mathrm{~m}$ distance between rows and columns and $3 \mathrm{~m}$ distance within columns (Figure 1.3).

\subsection{References}

Anderson,V.J. \& Briske,D.D. (1995) Herbivore-induced species replacement in grasslands - Is it driven by herbivory tolerance or avoidance. Ecological Applications, 5, 1014-1024.

Armstrong,R.H., Grant,S.A., Common,T.G. \& Beattie,M.M. (1997) Controlled grazing studies on Nardus grassland: effects of between tussock sward height and species of grazer on diet selection and intake. Grass and Forage Science, 52, 219-231.

Barnosky,A.D., Matzke,N., Tomiya,S., Wogan,G.O.U., Swartz,B., Quental,T.B., Marshall,C., McGuire,J.L., Lindsey,E.L., Maguire,K.C., Mersey,B. \& Ferrer,E.A. (2011) Has the Earth's sixth mass extinction already arrived? Nature, 471, 51-57.

Bonachela,S. (1996) Root growth of triticale and barley grown for grain or for forage-plus-grain in a Mediterranean climate. Plant and Soil, 183, 239-251.

Caldwell,M.M., Richards,J.H., Johnson,D.A., Nowak,R.S. \& Dzurec,R.S. (1981) Coping with herbivory - Photosynthetic capacity and resource-allocation in 2 semi-arid Agropyron bunchgrasses. Oecologia, 50, 14-24.

Chapin,F.S., Walker,B.H., Hobbs,R.J., Hooper,D.U., Lawton,J.H., Sala,O.E. \& Tilman,D. (1997) Biotic control over the functioning of ecosystems. Science, 277, 500-504.

Chase,J.M. \& Leibold,M.A. (2002) Spatial scale dictates the productivity-biodiversity relationship. Nature, 416, 427-430.

Craine,J.M., Froehle,J., Tilman,D.G., Wedin,D.A. \& Chapin,F.S. (2001) The relationships among root and leaf traits of 76 grassland species and relative abundance along fertility and disturbance gradients. Oikos, 93, 274-285. 
Darwin,C. (1859) On the Origin of Species by Means of Natural Selection. J. Murray, London.

Dawson,L.A., Graystone,S.J. \& Paterson,E. (2000) Effects of grazing on the roots and rhizosphere of grasses. Grassland Ecophysiology and Grazing Ecology. (ed. by G.Lemaire, J.Hodgson, A.de Moraes, C.Nabinger and P.C.De F.Carvalho), pp. 61-84. CABI Publishing, Wallingford.

Díaz,S., Acosta,A. \& Cabido,M. (1992) Morphological analysis of herbaceous communities under different grazing regimes. Journal of Vegetation Science, 3, 689-696.

Díaz,S., Hodgson,J.G., Thompson,K., Cabido,M., Cornelissen,J.H.C., Jalili,A., Montserrat-Marti,G., Grime,J.P., Zarrinkamar,F., Asri,Y., Band,S.R., Basconcelo,S., Castro-Diez,P., Funes, G., Hamzehee,B., Khoshnevi,M., Perez-Harguindeguy,N., Perez-Rontome,M.C., Shirvany,F.A., Vendramini,F., Yazdani,S., bbas-Azimi,R., Bogaard,A., Boustani,S., Charles,M., Dehghan,M., de Torres-Espuny,L., Falczuk,V., Guerrero-Campo,J., Hynd,A., Jones,G., Kowsary,E., Kazemi-Saeed,F., Maestro-Martinez,M., Romo-Diez,A., Shaw,S., Siavash,B., Villar-Salvador,P. \& Zak,M.R. (2004) The plant traits that drive ecosystems: Evidence from three continents. Journal of Vegetation Science, 15, 295-304.

Dimitrakopoulos,P.G. \& Schmid,B. (2004) Biodiversity effects increase linearly with biotope space. Ecology Letters, 7, 574-583.

Ellenberg,H. \& Leuschner,C. (2010) Vegetation Mitteleuropas mit den Alpen. $\left(6^{\text {th }}\right.$ ed.) Ulmer Verlag, Stuttgart.

Ellis,J.E., Wiens,J.A., Rodell,C.F. \& Anway,J.C. (1976) Conceptual-model of diet selection as an ecosystem process. Journal of Theoretical Biology, 60, 93-108.

Fornara,D.A. \& Tilman,D. (2008) Plant functional composition influences rates of soil carbon and nitrogen accumulation. Journal of Ecology, 96, 314-322.

Garnier,E. (1992) Growth analysis of congeneric annual and perennial grass species. Journal of Ecology, 80, 665-675.

Garnier,E., Cordonnier,P., Guillerm,J.L. \& Sonie,L. (1997) Specific leaf area and leaf nitrogen concentration in annual and perennial grass species growing in Mediterranean old-fields. Oecologia, 111, 490-498.

Gass,P. \& Oertli,J.J. (1980) Durchwurzelungsvergleich zwischen Fettwiese und angrenzender Brachwiese. Zeitschrift für Pflanzenernährung und Bodenkunde, 143, 208-214.

Gough,L., Osenberg,C.W., Gross,K.L. \& Collins,S.L. (2000) Fertilization effects on species density and primary productivity in herbaceous plant communities. Oikos, 89, 428-439.

Grace,J.B., Anderson,T.M., Smith,M.D., Seabloom,E., Andelman,S.J., Meche,G., Weiher,E., Allain,L.K., Jutila,H., Sankaran,M., Knops,J., Ritchie,M. \& Willig,M.R. (2007) Does species diversity limit productivity in natural grassland communities? Ecology Letters, 10, 680-689.

Grant,S.A., Suckling,D.E., Smith,H.K., Torvell,L., Forbes,T.D.A. \& Hodgson,J. (1985) Comparative studies of diet selection by sheep and cattle - the Hill Grasslands. Journal of Ecology, 73, 987 1004 .

Greenwood,E.A.N., Turner,N.C., Schulze,E.D., Watson,G.D. \& Venn,N.R. (1992) Groundwatermanagement through increased water-use by lupin crops. Journal of Hydrology, 134, 1-11.

Grime,J.P. (1998) Benefits of plant diversity to ecosystems: immediate, filter and founder effects. Journal of Ecology, 86, 902-910. 
Grime,J.P. (2002) Declining plant diversity: empty niches or functional shifts? Journal of Vegetation Science, 13, 457-460.

Gross,N., Bloor,J.M.G., Louault,F., Maire,V. \& Soussana,J.F. (2009) Effects of land-use change on productivity depend on small-scale plant species diversity. Basic and Applied Ecology, 10, 687-696.

Hansson,M. \& Fogelfors,H. (2000) Management of a semi-natural grassland; results from a 15-yearold experiment in southern Sweden. Journal of Vegetation Science, 11, 31-38.

Hector,A., Schmid,B., Beierkuhnlein,C., Caldeira,M.C., Diemer,M., Dimitrakopoulos,P.G., Finn,J.A., Freitas,H., Giller,P.S., Good,J., Harris,R., Hogberg,P., Huss-Danell,K., Joshi,J., Jumpponen,A., Körner,C., Leadley,P.W., Loreau,M., Minns,A., Mulder,C.P.H., O'Donovan,G., Otway,S.J., Pereira,J.S., Prinz,A., Read,D.J., Scherer-Lorenzen,M., Schulze,E.D., Siamantziouras,A.S.D., Spehn,E.M., Terry,A.C., Troumbis,A.Y., Woodward,F.I., Yachi,S. \& Lawton,J.H. (1999) Plant diversity and productivity experiments in European grasslands. Science, 286, 1123-1127.

Hector,A. (2001) Biodiversity and functioning of grassland ecosystems: multi-site comparison. The Functional Consequences of Biodiversity: Empirical Progress and Theoretical Extensions (ed. by A.P.Kinzig, S.W.Pacala and D.Tilman), pp. 71-95. Princton University Press, Princton.

Hector,A. \& Bagchi,R. (2007) Biodiversity and ecosystem multifunctionality. Nature, 448, 188-190.

Hooper,D.U. \& Vitousek,P.M. (1998) Effects of plant composition and diversity on nutrient cycling. Ecological Monographs, 68, 121-149.

Hooper,D.U. (1998) The role of complementarity and competition in ecosystem responses to variation in plant diversity. Ecology, 79, 704-719.

Hooper,D.U., Chapin,F.S., Ewel,J.J., Hector,A., Inchausti,P., Lavorel,S., Lawton,J.H., Lodge,D.M., Loreau,M., Naeem,S., Schmid,B., Setala,H., Symstad,A.J., Vandermeer,J. \& Wardle,D.A. (2005) Effects of biodiversity on ecosystem functioning: A consensus of current knowledge. Ecological Monographs, 75, 3-35.

Husemann,C. \& Wesche,J. (1964) Der Wasserhaushalt und die Wasserbilanz eines lehm. Sandbodens nach Untersuchungen in wägbaren Lysimetergefäßen. Zeitschrift für Kulturtechnick und Flurbereinigung, 5, 364-389.

Huston,M.A. (1997) Hidden treatments in ecological experiments: Re-evaluating the ecosystem function of biodiversity. Oecologia, 110, 449-460.

Huston,M.A., Aarssen,L.W., Austin,M.P., Cade,B.S., Fridley,J.D., Garnier,E., Grime,J.P., Hodgson,J., Lauenroth,W.K., Thompson,K., Vandermeer,J.H. \& Wardle,D.A. (2000) No consistent effect of plant diversity on productivity. Science, 289.

Jacquemyn,H., Brys,R. \& Hermy,M. (2003) Short-term effects of different management regimes on the response of calcareous grassland vegetation to increased nitrogen. Biological Conservation, 111, 137-147.

Joshi,J., Matthies,D. \& Schmid,B. (2000) Root hemiparasites and plant diversity in experimental grassland communities. Journal of Ecology, 88, 634-644.

Kahmen,A., Perner,J., Audorff,V., Weisser,W. \& Buchmann,N. (2005) Effects of plant diversity, community composition and environmental parameters on productivity in montane European grasslands. Oecologia, 142, 606-615. 
Kahmen,A., Renker,C., Unsicker,S.B. \& Buchmann,N. (2006) Niche complementarity for nitrogen: An explanation for the biodiversity and ecosystem functioning relationship? Ecology, 87, 1244-1255.

Kahmen,S., Poschlod,P. \& Schreiber,K.F. (2002) Conservation management of calcareous grasslands. Changes in plant species composition and response of functional traits during 25 years. Biological Conservation, 104, 319-328.

Kenkel,N.C., Peltzer,D.A., Baluta,D. \& Pirie,D. (2000) Increasing plant diversity does not influence productivity: empirical evidence and potential mechanisms. Community Ecology, 1, 165-170.

Klapp,E. (1971) Wiesen Und Weiden: Eine Grünlandlehre. (4 ${ }^{\text {th }}$ ed.) Parey-Verlag, Berlin/Hamburg.

Klimek,S., Kemmermann,A.R.G., Hofmann,M. \& Isselstein,J. (2007) Plant species richness and composition in managed grasslands: The relative importance of field management and environmental factors. Biological Conservation, 134, 559-570.

Klimek,S., Marini,L., Hofmann,M. \& Isselstein,J. (2008) Additive partitioning of plant diversity with respect to grassland management regime, fertilisation and abiotic factors. Basic and Applied Ecology, 9, 626-634.

Krahulec,F., Skálová,H., Herben,T., Hadincová,V., Wildová.R. \& Pecháčková,S. (2001) Vegetation changes following sheep grazing in abandoned mountain meadows. Applied Vegetation Science, 4, 97-102.

Krause,B., Culmsee,H., Wesche,K., Bergmeier,E. \& Leuschner,C. (2011) Habitat loss of floodplain meadows in north Germany since the 1950s. Biodiversity and Conservation, Early View.

Liu,X.Z. \& Huang,B.R. (2002) Mowing effects on root production, growth, and mortality of creeping bentgrass. Crop Science, 42, 1241-1250.

Loreau,M., Naeem,S., Inchausti,P., Bengtsson,J., Grime,J.P., Hector,A., Hooper,D.U., Huston,M.A., Raffaelli,D., Schmid,B., Tilman,D. \& Wardle,D.A. (2001) Biodiversity and ecosystem functioning: Current knowledge and future challenges. Science, 294, 804-808.

MacArthur,R.H. \& Wilson,E.O. (1967) The Theory of Island Biogeography. Princeton University Press, Princeton.

Marquard,E., Weigelt,A., Temperton,V.M., Roscher,C., Schumacher,J., Buchmann,N., Fischer,M., Weisser,W.W. \& Schmid,B. (2009) Plant species richness and functional composition drive overyielding in a six-year grassland experiment. Ecology, 90, 3290-3302.

Maurer,K., Weyand,A., Fischer,M. \& Stöcklin,J. (2006) Old cultural traditions, in addition to land use and topography, are shaping plant diversity of grasslands in the Alps. Biological Conservation, 130, 438-446.

McIntyre,S., Lavorel,S., Landsberg,J. \& Forbes,T.D.A. (1999) Disturbance response in vegetation towards a global perspective on functional traits. Journal of Vegetation Science, 10, 621-630.

Monteith,J.L. (1988) Does transpiration limit the growth of vegetation or vice versa? Journal of Hydrology, 100, 57-68.

Naeem,S., Thompson,L.J., Lawler,S.P., Lawton,J.H. \& Woodfin,R.M. (1994) Declining biodiversity can alter the performance of ecosystems. Nature, 368, 734-737.

Oksanen,J. (1996) Is the humped relationship between species richness and biomass an artefact due to plot size? Journal of Ecology, 84, 293-295. 
Oomes,M.J.M. (1992) Yield and species density of grasslands during restoration management. Journal of Vegetation Science, 3, 271-274.

Patty,L., Halloy,S.R.P., Hiltbrunner,E. \& Körner,C. (2010) Biomass allocation in herbaceous plants under grazing impact in the high semi-arid Andes. Flora, 205, 695-703.

Petersen,U., Wrage,N., Köhler,L., Leuschner,C. \& Isselstein,J. (2010) Manipulating spechies richness in permanent grasslands - a new approach to biodiversity experiments. Grassland Science in Europe, 15, 824-826.

Petersen,U., Isselstein,J. \& Wrage,N. (2010) The effect of manipulated plant species diversity of seminatural permanent grassland on forage production and quality. Grassland Science in Europe, $15,821-823$.

Polley,H.W., Johnson,H.B., Fay,P.A. \& Sanabria,J. (2008) Initial response of evapotranspiration from tallgrass prairie vegetation to $\mathrm{CO}_{2}$ at subambient to elevated concentrations. Functional Ecology, 22, 163-171.

Poorter,H. \& De Jong,R. (1999) A comparison of specific leaf area, chemical composition and leaf construction costs of field plants from 15 habitats differing in productivity. New Phytologist, 143, 163-176.

Quétier,F., Thébault,A. \& Lavorel,S. (2007) Plant traits in a state and transition framework as markers of ecosystem response to land-use change. Ecological Monographs, 77, 33-52.

Reich,P.B., Buschena,C., Tjoelker,M.G., Wrage,K., Knops,J., Tilman,D. \& Machado,J.L. (2003) Variation in growth rate and ecophysiology among 34 grassland and savanna species under contrasting N supply: a test of functional group differences. New Phytologist, 157, 617-631.

Reynolds,H.L. \& D' Antonio,C. (1996) The ecological significance of plasticity in root weight ratio in response to nitrogen: Opinion. Plant and Soil, 185, 75-97.

Richards,J.H. (1984) Root-growth response to defoliation in 2 Agropyron bunchgrasses - Field observations with an improved root periscope. Oecologia, 64, 21-25.

Roscher,C., Temperton,V.M., Scherer-Lorenzen,M., Schmitz,M., Schumacher,J., Schmid,B., Buchmann,N., Weisser,W.W. \& Schulze,E.D. (2005) Overyielding in experimental grassland communities - irrespective of species pool or spatial scale. Ecology Letters, 8, 419-429.

Rosset,M., Montani,M., Tanner,M. \& Fuhrer,J. (2001) Effects of abandonment on the energy balance and evapotranspiration of wet subalpine grassland. Agriculture Ecosystems \& Environment, 86, 277-286.

Rueda,M., Rebollo,S. \& Rodriguez,M.A. (2010) Habitat productivity influences root mass vertical distribution in grazed Mediterranean ecosystems. Acta Oecologica-International Journal of Ecology, 36, 377-382.

Ryser,P. \& Eek,L. (2000) Consequences of phenotypic plasticity vs. interspecific differences in leaf and root traits for acquisition of aboveground and belowground resources. American Journal of Botany, 87, 402-411.

Sala,O.E., Chapin,F.S., Armesto,J.J., Berlow,E., Bloomfield,J., Dirzo,R., Huber-Sanwald,E., Huenneke,L.F., Jackson,R.B., Kinzig,A., Leemans,R., Lodge,D.M., Mooney,H.A., Oesterheld,M., Poff,N.L., Sykes,M.T., Walker,B.H., Walker,M. \& Wall,D.H. (2000) Global biodiversity scenarios for the year 2100. Science, 287, 1770-1774. 
Scherer-Lorenzen,M., Palmborg,C., Prinz,A. \& Schulze,E.D. (2003) The role of plant diversity and composition for nitrate leaching in grasslands. Ecology, 84, 1539-1552.

Schippers,P., Snoeijing,I. \& Kropff,M.J. (1999) Competition under high and low nutrient levels among three grassland species occupying different positions in a successional sequence. New Phytologist, 143, 547-559.

Schmid,B., Joshi,J. \& Schläpfer,F. (2001) Empirical evidence for biodiversity- ecosystem functioning relationships. The Functional Consequences of Biodiversity: Empirical Progress and Theoretical Extensions (ed. by A.P.Kinzig, S.W.Pacala and D.Tilman), pp. 120-150. Princeton University Press, Princeton.

Schulze,E.D., Kelliher,F.M., Körner,C., Lloyd,J. \& Leuning,R. (1994) Relationships among maximum stomatal conductance, ecosystem surface conductance, carbon assimilation rate, and plant nitrogen nutrition - A global ecology scaling exercise. Annual Review of Ecology and Systematics, 25, 629-660.

Seither,M., Petersen,U., Wrage,N. \& Isselstein,J. (2010) Effect of mono- and mixed grazing of cattle and sheep on grassland diversity patterns. Grassland Science in Europe, 15, 755-757.

Silvertown,J. (1980) The dynamics of a grassland ecosystem - Botanical equilibrium in the Park Grass Experiment. Journal of Applied Ecology, 17, 491-504.

Smith,M.D. \& Knapp,A.K. (2003) Dominant species maintain ecosystem function with non-random species loss. Ecology Letters, 6, 509-517.

Spehn,E.M., Hector,A., Joshi,J., Scherer-Lorenzen,M., Schmid,B., Bazeley-White,E., Beierkuhnlein,C., Caldeira,M.C., Diemer,M., Dimitrakopoulos,P.G., Finn,J.A., Freitas,H., Giller,P.S., Good,J., Harris,R., Hogberg,P., Huss-Danell,K., Jumpponen,A., Koricheva,J., Leadley,P.W., Loreau,M., Minns,A., Mulder,C.P.H., O'Donovan,G., Otway,S.J., Palmborg,C., Pereira,J.S., Pfisterer,A.B., Prinz,A., Read,D.J., Schulze,E.D., Siamantziouras,A.S.D., Terry,A.C., Troumbis,A.Y., Woodward,F.I., Yachi,S. \& Lawton,J.H. (2005) Ecosystem effects of biodiversity manipulations in European grasslands. Ecological Monographs, 75, 3763.

Speidel,B. \& Weiss,A. (1972) Zur ober- und unterirdischen Stoffproduktion einer Goldhaferwiese bei verschiedener Düngung. Angewandte Botanik, 46, 75-93.

Suding,K.N., Miller,A.E., Bechtold,H. \& Bowman,W.D. (2006) The consequence of species loss on ecosystem nitrogen cycling depends on community compensation. Oecologia, 149, 141-149.

Tasser,E. \& Tappeiner,U. (2002) Impact of land use changes on mountain vegetation. Applied Vegetation Science, 5, 173-184.

Thompson,K., Askew,A.P., Grime,J.P., Dunnett,N.P. \& Willis,A.J. (2005) Biodiversity, ecosystem function and plant traits in mature and immature plant communities. Functional Ecology, 19, 355-358.

Tilman,D. (1987) Secondary succession and the pattern of plant dominance along experimental nitrogen gradients. Ecological Monographs, 57, 189-214.

Tilman,D. (1993) Species richness of experimental productivity gradients - How important is colonization limitation? Ecology, 74, 2179-2191.

Tilman,D. \& Downing,J.A. (1994) Biodiversity and stability in grasslands. Nature, 367, 363-365. 
Tilman,D., Wedin,D.A. \& Knops,J. (1996) Productivity and sustainability influenced by biodiversity in grassland ecosystems. Nature, 379, 718-720.

Tilman,D., Naeem,S., Knops,J., Reich,P., Siemann,E., Wedin,D.A., Ritchie,M. \& Lawton,J. (1997) Biodiversity and ecosystem properties. Science, 278, 1866-1867.

Tilman,D., Fargione,J., Wolff,B., D'Antonio,C., Dobson,A., Howarth,R., Schindler,D., Schlesinger,W.H., Simberloff,D. \& Swackhamer,D. (2001) Forecasting agriculturally driven global environmental change. Science, 292, 281-284.

Tomanek,G.W. \& Albertson,F.W. (1957) Variations in cover, composition, production, and roots of vegetation on 2 prairies in Western Kansas. Ecological Monographs, 27, 267-281.

Van Peer,L., Nijs,I., Reheul,D. \& De Cauwer,B. (2004) Species richness and susceptibility to heat and drought extremes in synthesized grassland ecosystems: compositional vs. physiological effects. Functional Ecology, 18, 769-778.

Vandenberghe,C., Prior,G., Littlewood,N.A., Brooker,R. \& Pakeman,R. (2009) Influence of livestock grazing on meadow pipit foraging behaviour in upland grassland. Basic and Applied Ecology, 10, 662-670.

Verheyen,K., Bulteel,H., Palmborg,C., Olivie,B., Nijs,I., Raes,D. \& Muys,B. (2008) Can complementarity in water use help to explain diversity-productivity relationships in experimental grassland plots? Oecologia, 156, 351-361.

Vitousek,P.M. (1994) Beyond global warming - Ecology and global change. Ecology, 75, 1861-1876.

Vitousek,P.M., Mooney,H.A., Lubchenco,J. \& Melillo,J.M. (1997) Human domination of earth's ecosystems. Science, 277, 494-499.

Waesch,G. (2003) Montane Graslandvegetation Des Thüringer Waldes. Cuvillier Verlag, Göttingen.

Wardle,D.A. (1999) Is "sampling effect" a problem for experiments investigating biodiversityecosystem function relationships? Oikos, 87, 403-407.

Wesche,K., Krause,B., Culmsee,H. \& Leuschner,C. (2009) Veränderungen in der FlächenAusdehnung und Artenzusammensetzung des Feuchtgrünlandes in Norddeutschland seit den 1950er Jahren. Berichte der Reinhold-Tüxen-Gesellschaft, 21, 196-210.

Whittaker,R.H. (1965) Dominance and diversity in land plant communities - numerical relations of species express importance of competition in community function and evolution. Science, 147, $250-\&$.

Wilson,S.D. \& Shay,J.M. (1990) Competition, fire, and nutrients in a mixed-grass prairie. Ecology, 71, 1959-1967.

Wind,M.P.G. Incidence de la fertilisation azotée sur la consommation en eau des herbages. Conf. Eur. des Herbages. 211-214. 1954. Paris, OECE.

Wright,I.J. \& Westoby,M. (2002) Leaves at low versus high rainfall: coordination of structure, lifespan and physiology. New Phytologist, 155, 403-416. 
Wright,I.J., Reich,P.B., Westoby,M., Ackerly,D.D., Baruch,Z., Bongers,F., Cavender-Bares,J., Chapin,T., Cornelissen,J.H.C., Diemer,M., Flexas,J., Garnier,E., Groom,P.K., Gulias,J., Hikosaka,K., Lamont,B.B., Lee,T., Lee,W., Lusk,C., Midgley,J.J., Navas,M.L., Niinemets,U., Oleksyn,J., Osada,N., Poorter,H., Poot,P., Prior,L., Pyankov,V.I., Roumet,C., Thomas,S.C., Tjoelker,M.G., Veneklaas,E.J. \& Villar,R. (2004) The worldwide leaf economics spectrum. Nature, 428, 821-827.

Yachi,S. \& Loreau,M. (2007) Does complementary resource use enhance ecosystem functioning? A model of light competition in plant communities. Ecology Letters, 10, 54-62. 



\section{CHAPTER 2}

Effects of different livestock types on biomass and nitrogen partitioning in temperate pastures with different functional group abundances

Laura Rose, Dietrich Hertel, Christoph Leuschner 


\subsection{Abstract}

Livestock grazing can be a means to maintain biodiversity in grasslands, but the outcome for vegetation structure and species composition depends on livestock type and grazing regime. We investigated effects of cattle, sheep and co-grazing of both on aboveground and belowground biomass and plant $\mathrm{N}$ pools in a replicated grazing experiment. We applied herbicides to generate two pasture communities with different functional group abundances (diverse vs. grass-dominated).

In the six treatments, aboveground biomass (AGB) was reduced up to $80 \%$, compared to an ungrazed control, while belowground biomass was not altered. Cattle reduced AGB to a larger extent than sheep in diverse pastures while sheep grazing tended to do so in grassdominated pastures. The aboveground $\mathrm{N}$ pool was less reduced than biomass, because grazing reduced the $\mathrm{C} / \mathrm{N}$ ratio of aboveground biomass relative to the ungrazed control. We conclude that livestock type and functional group abundance are interacting factors influencing plant biomass and $\mathrm{N}$ pools in temperate pastures. 


\subsection{Introduction}

Grazing with livestock can be a strategy to meet the demands of both economy and biodiversity conservation if stocking density and fertilizer input are not too high. Extensively used grasslands belong to the most species-rich ecosystems in Central Europe with up to 70 plant species per $20 \mathrm{~m}^{2}$ (Ellenberg \& Leuschner 2010). However, in the last 50 years, speciesrich pastures and meadows disappeared in Central Europe at an alarming rate due to land use intensification, in particular high nitrogen and phosphorus inputs, high cutting frequencies and stocking rates (e.g., Krahulec et al. 2001, Tasser \& Tappeiner 2002, Krause et al. 2011). Simultaneously, an increasing abundance of high grasses on the expense of legumes and herbs occurred as a consequence of synthetic fertilizer application (Dierschke \& Briemle 2002).

The abundance of different functional groups of plants in the community may alter the grazing behaviour of livestock (i.e., the amount and type of biomass removed; Allen 2000). In turn, different types of livestock can influence the species composition of pastures differently due to their specific grazing behaviour (Armstrong et al. 1997, Dumont et al. 2011). For example, sheep have a more selective grazing behaviour than cattle and preferably feed on legumes and herbs (Ellis et al. 1976). Because of the higher nitrogen content of legumes and non-legume herbs compared to grasses (Klapp 1971), differences in functional group preference have the potential to severely alter the impact of different grazers on aboveground biomass and nitrogen removal.

Defoliation greatly reduces the photosynthetic tissue and often modifies carbon allocation patterns and root growth activity (Tomanek \& Albertson 1957, Gass \& Oertli 1980, Richards 1984, Bonachela 1996, Liu \& Huang 2002, Patty et al. 2010, Rueda et al. 2010). While most research on grazing effects in managed and natural grasslands has focused on aboveground biomass, the response of the root system to different grazing regimes is not well studied (Rueda et al. 2010). This gap of knowledge is unsatisfactory because belowground biomass is often larger than aboveground grassland biomass and a large fraction of annual carbon gain (up to $>70 \%$ ) is transferred to the roots in certain grasslands (Speidel \& Weiß 1972, Jackson et al. 1996).

According to our knowledge there are no studies so far that aimed at disentangling the effects of functional group abundance and livestock type on the above- and belowground biomass and nitrogen allocation in temperate pastures. We quantified the $\mathrm{N}$ pools in above- 
and belowground biomass as indicators of the $\mathrm{N}$ uptake and preferential $\mathrm{N}$ allocation of the grassland plants under grazing influence.

The aim of this study is to answer the following questions:

i) How do cattle and sheep differ in their grazing effect on pasture biomass and biomass $\mathrm{N}$ pool? ii) Is there a reciprocal effect of the pasture's species composition (abundance of herbs and legumes) on the grazing effect of cattle and sheep? iii) Is there a livestock type effect on the grazing effect on belowground biomass and the root $\mathrm{N}$ pool?

\subsection{Material and methods}

\subsubsection{Study site and experimental design}

The study was conducted within the framework of the interdisciplinary 'BIOMIX' project at the University of Goettingen on pastures of the experimental farm Relliehausen at the foothills of the Solling Mountains, central Germany (51\%/46` N, 9\%/41` E, $180 \mathrm{~m}$ a.s.1.). Mean annual temperature is $8.2{ }^{\circ} \mathrm{C}$ and mean annual precipitation is $879 \mathrm{~mm}$ (DWD 19611990). The grassland community on the study plots represents a mesotrophic variant of the wide-spread Lolio-Cynosuretum pasture association. The soil type is a pelosol with a clayey to silty loam texture. The site has been used as a mown pasture for at least 15 years and cattle manure has been regularly applied during that time (Seither et al. 2010). The most abundant grass species were Lolium perenne L., Dactylis glomerata L., Festuca rubra L., while Taraxacum sect. Ruderalia Kirschner, H. Ollg. \& Stepanek and Trifolium repens L. were the most abundant herb and legume species, respectively.

The full-factorial block design of the study includes two functional group abundance levels and three livestock types leading to six different treatments. Eighteen 0.5 ha-plots were installed in three blocks (A, B, C) each consisting of six pasture plots. Half of the plots were treated with the herbicides Fluroxypyr (Starane; Dow AgroSciences, Munich, Germany) and Mecoprop-P (Duplosan; KV, Du Pont de Nemours, Neu-Isenburg, Germany) on September 14, 2006, to exclude legumes and non-legume herbs, thereby creating swards dominated by monocotyledonous species. Thus, the herbicide application resulted in pastures with an increased abundance of monocots (grass-dominated) and pastures with the original composition of monocot and dicot species (diverse). To evaluate the effect of the 2006 herbicide application on sward diversity, we conducted a PERMANOVA analysis using 
Sørensen's distance index for species abundance data from 2008 as a measure and tested for the influence of the factors 'herbicide', 'livestock type' and their interaction. Accordingly, herbicide application had a significant effect $(P<0.01)$ on species composition whereas livestock type had not.

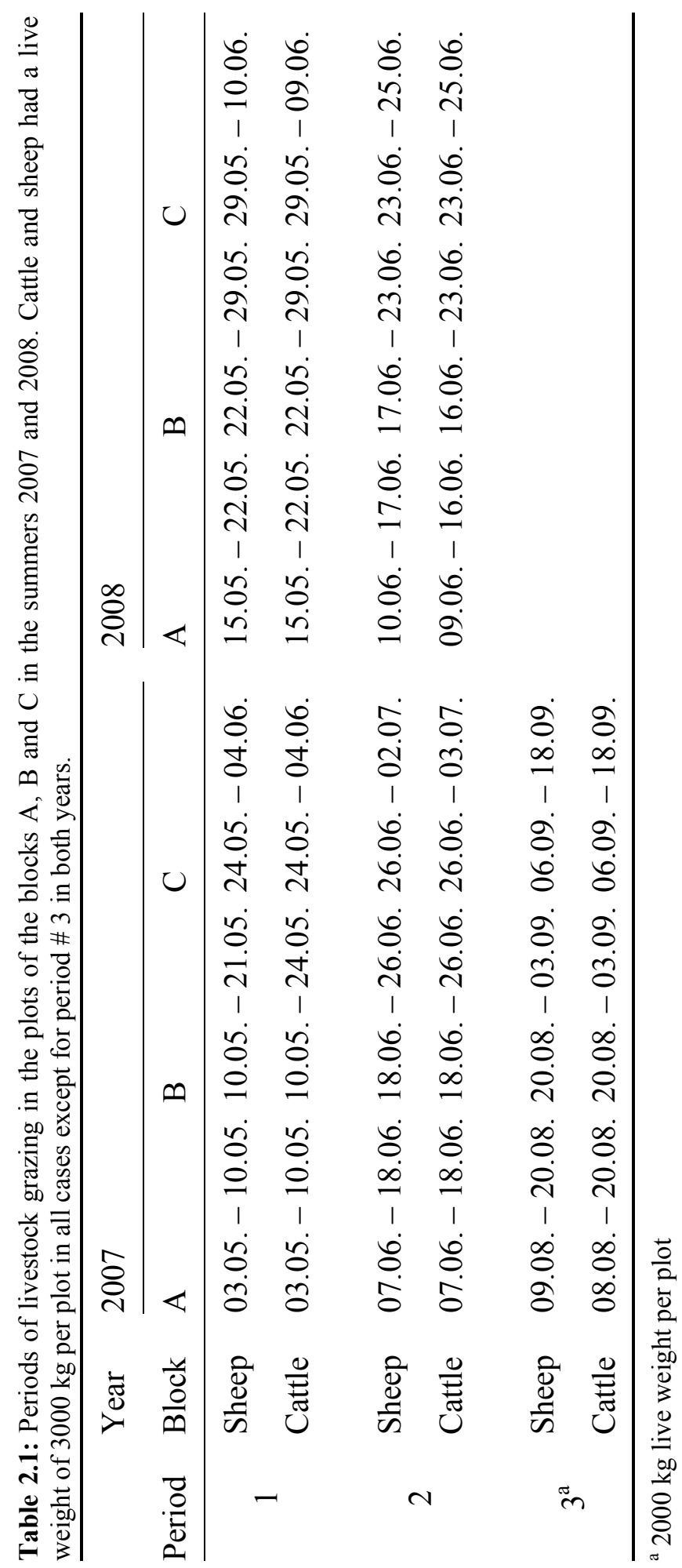


Grazing with cattle, sheep or co-grazing with both animals (mixed stocking, $50 \%$ sheep and $50 \%$ cattle in terms of live weight) was conducted in a rotational stocking system (Allen et al. 2011) between the three blocks with $3000 \mathrm{~kg}$ animal live weight per plot in all treatments (12 livestock units per ha). Livestock remained for a period of two to thirteen days on each block before it was transferred to the next block to avoid fodder shortage (Table 2.1). Grazing started on May 3, 2007, and on May 15, 2008, with three rotation periods in 2007 and three rotations in 2008. In 2008, a fenced area of $70 \mathrm{~m}^{2}$ was demarcated in each plot to serve as ungrazed control. Although these control areas had been subject to different grazing regimes in 2007, we argue that these plots without grazing for one season represent the best possible control in our experiment. Different livestock grazing in 2007 had no significant effect on the vegetation structure in 2008 in these plots. We preferred this type of control over other possible reference systems such as pastures with a longer fallow period or mown grasslands, because data from vegetation science and succession research show rapid changes in the species composition of pastures of the study region when grazing is abandoned or is replaced by a mowing regime. Thus, the result would be a grassland community hardly comparable to the experimental plots.

\subsubsection{Vegetation analysis and biomass sampling}

We analysed the structure and composition of the vegetation in July 2008 after three grazing cycles in 2007 and two in 2008 . In each plot, two subplots $\left(0.25 \mathrm{~m}^{2}\right)$ with a minimum distance of $20 \mathrm{~m}$ to each other were randomly selected in the grazed area and one subplot was selected in the ungrazed area for vegetation analysis and biomass sampling.

In each subplot, a vegetation analysis was conducted between July 2 and July 5, 2008 and the aboveground biomass was harvested by clipping the plants immediately above the soil surface; the plant material was sorted into the three functional groups legumes, non-legume dicotyle herbs and grasses.

To measure belowground biomass, we extracted three soil samples per subplot between July 6 and July 8, 2008 using a soil corer $(3.5 \mathrm{~cm}$ in diameter) to a depth of $20 \mathrm{~cm}$. Each sample was divided into two subsamples $(0-10 \mathrm{~cm}$ and $10-20 \mathrm{~cm}$ soil depth). The roots were cleaned of attached soil residues using a sieve with a mesh size of $0.2 \mathrm{~mm}$, dried $\left(70{ }^{\circ} \mathrm{C}, 80 \mathrm{~h}\right)$ and weighed. Because separation between living and dead roots was not possible, all root data 
refer to total root mass. The effect of grazing on biomass was quantified by expressing the grazed plot data as percent of the ungrazed control.

The dried plant material was ground and $\mathrm{N}$ concentrations were determined with a $\mathrm{C} / \mathrm{N}$ autoanalyser (vario EL III; elementar Analysensysteme, Hanau, Germany) and the total above- and belowground biomass pools of nitrogen (unit: $\mathrm{g} \mathrm{N} \mathrm{m}^{-2}$ ) were calculated from data of biomass and $\mathrm{N}$ concentrations.

\subsubsection{Statistical analyses}

Statistical analyses were performed using SAS version 8.02 (SAS Institute, Cary, USA). A significance level of $P \leq 0.05$ was used throughout and subplots were used as replicates. All data were tested for normal distribution (Shapiro-Wilk test). Two-way analyses of variance with the source variables functional group abundance (diverse vs. grass-dominated pastures), livestock type (cattle, sheep, co-grazed) and their interaction were performed by the ANOVA procedure for all data. Differences between two treatments were analysed with a post-hoc Scheffé test. The control plot data were included in the post-hoc test but not in the ANOVA runs to avoid a masking of livestock type effects. Since livestock type had no impact on the control values of any of the measured variables, the control values of the three livestock treatments were pooled per functional group treatment to get a mean control value for each variable.

\subsection{Results}

\subsubsection{Treatment effects on plant diversity}

The $\alpha$-diversity of higher plants (species richness) in the plots with different grazing treatment ranged between 4.7 and 8.1 species per $0.25 \mathrm{~m}^{2}$ on average (Table 2.2). It was significantly influenced by the herbicide application, but not by livestock type nor by the interaction of both (Table 2.3). The highest number of species per subplot was found in the 'diverse pastures' under cattle grazing, while sheep-grazed pastures of the grass-dominated treatments harboured the lowest number of species (Table 2).

The main difference in community composition between the two functional group abundance types was a higher dominance of grasses and a reduced percentage of legumes and 
non-legume herbs in the grass-dominated compared to the diverse pastures regardless of livestock type. Accordingly, these findings allowed for analysing livestock type and functional group abundance as two independent factors.

The percentage of vegetation cover ranged between 91.3 and $97.7 \%$ and was influenced neither by functional group abundance nor livestock type or the interaction of the two factors (Table 2.3).

Table 2.2: $\alpha$-diversity and vegetation cover of the grazed $(n=6)$ and ungrazed control $(n=9)$ plots in July 2008 (means \pm SE). Different capital letters show significant differences between the functional group treatments of a livestock treatment, different lower-case letters show significant differences between the livestock treatments within a functional group treatment (t-test: $P<0.05)$.

\begin{tabular}{|c|c|c|c|c|c|c|c|c|c|c|c|c|c|c|c|c|}
\hline & \multicolumn{4}{|l|}{ Cattle } & \multicolumn{4}{|l|}{ Sheep } & \multicolumn{4}{|c|}{ Co-grazed } & \multicolumn{4}{|c|}{ Control } \\
\hline & Mean & \pm & SE & & Mean & \pm & SE & & Mean & \pm & SE & & Mean & \pm & SE & \\
\hline \multicolumn{17}{|l|}{$\begin{array}{l}\text { a-Diversity } \\
\text { (\# species) }\end{array}$} \\
\hline Diverse & 8.0 & \pm & 1.0 & $\mathrm{aA}$ & 6.2 & \pm & 0.5 & $\mathrm{aA}$ & 5.8 & \pm & 0.5 & $\mathrm{aA}$ & 7.2 & \pm & 0.7 & $\mathrm{aA}$ \\
\hline $\begin{array}{l}\text { Grass-dominated } \\
\text { Vegetation cover } \\
(\%)\end{array}$ & 5.2 & \pm & 0.5 & $\mathrm{aB}$ & 4.7 & \pm & 0.6 & $\mathrm{aA}$ & 5.5 & \pm & 0.8 & $\mathrm{aA}$ & 5.7 & \pm & 0.7 & $\mathrm{aA}$ \\
\hline Diverse & 95.5 & \pm & 3.1 & $\mathrm{aA}$ & 97.7 & \pm & 0.8 & $\mathrm{aA}$ & 96.0 & \pm & 2.4 & $\mathrm{aA}$ & 89.6 & \pm & 4.5 & $\mathrm{aA}$ \\
\hline Grass-dominated & 91.3 & \pm & 2.9 & $\mathrm{aA}$ & 95.2 & \pm & 1.1 & $\mathrm{aA}$ & 95.0 & \pm & 3.2 & $\mathrm{aA}$ & 87.8 & \pm & 3.5 & $\mathrm{aA}$ \\
\hline
\end{tabular}

\subsubsection{Biomass allocation}

The aboveground plant biomass (AGB) of the grazed plots ranged between ca. 95 and $270 \mathrm{~g} \mathrm{~m}^{-2}$ (Figure 2.1A) and was significantly influenced by the interaction of livestock type and functional group abundance $(P<0.05$, Table 2.3$)$. In the diverse pastures, cattle grazing led to a $62 \%$ lower aboveground biomass as compared to the two other livestock treatments. Further, the percentage of legumes in this treatment was significantly higher than in the sheep and co-grazed treatments (t-test, $P<0.05$, data not shown). AGB of the co-grazed pastures was not significantly different from that of sheep-grazed pastures, but tended to have a higher percentage of legume biomass. In the grass-dominated pastures, the three livestock treatments were not significantly different from each other in AGB, but sheep-grazed grass-dominated pastures tended to have lower values than the cattle or co-grazed treatments.

Belowground plant biomass (BGB) ranged between ca. 450 and $590 \mathrm{~g} \mathrm{~m}^{-2}$ (Figure 2.1B). It was less variable among treatments than aboveground biomass and no significant effect of livestock type, functional group abundance or their interaction was found (Table 2.3). 


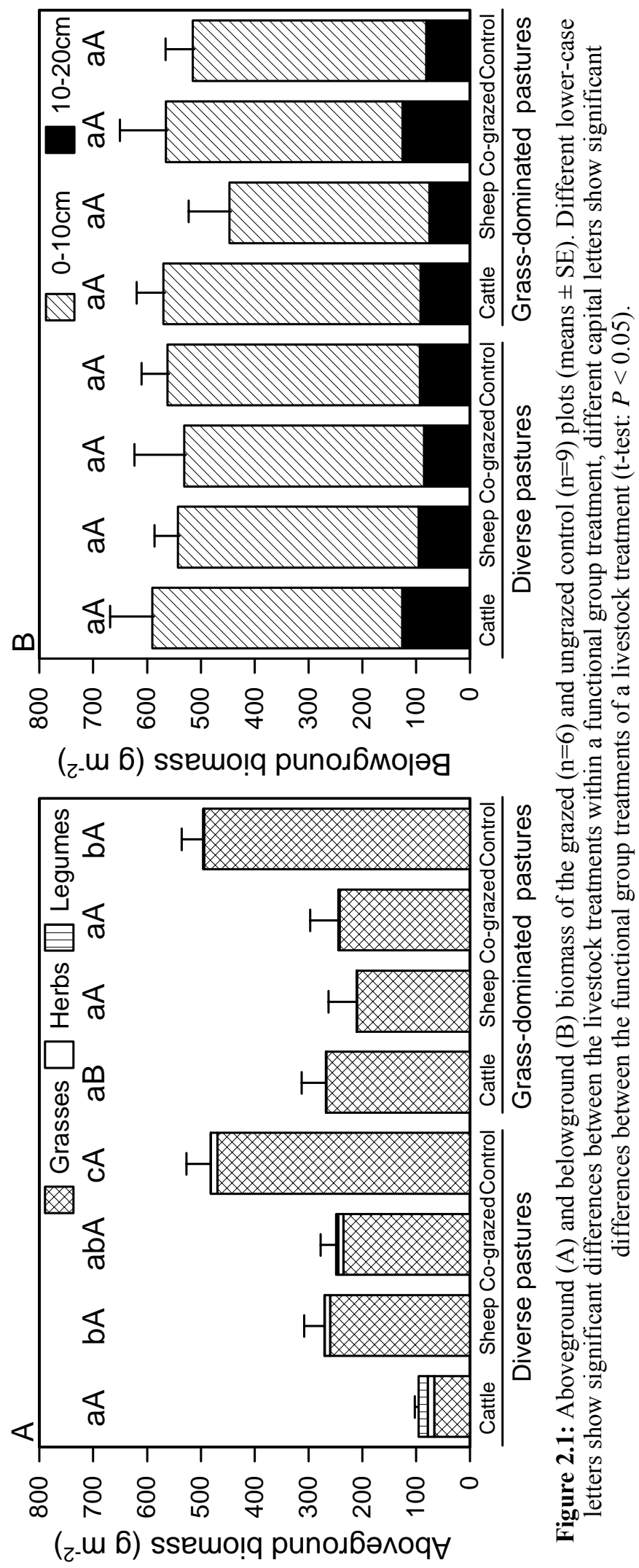


In the diverse plots, BGB was remarkably invariant among the treatments with ca. $440 \mathrm{~g}$ $\mathrm{m}^{-2}$ of root biomass being present in the upper $10 \mathrm{~cm}$ of the soil and ca. $100 \mathrm{~g} \mathrm{~m}^{-2}$ (i.e. ca. 16 $23 \%$ of the root biomass total) located in $10-20 \mathrm{~cm}$ soil depth. In the grass-dominated pastures, the cattle and co-grazed treatments showed root biomass values in the two soil depths that were very similar to the diverse plots. In contrast, sheep-grazed grass-dominated pastures revealed a (non significant) tendency for a lower root biomass at both soil depths, when compared to the diverse pastures.

Table 2.3: Summary of ANOVA results on the effect of the variables 'functional group abundance', 'livestock type' and the interaction of both on 10 parameters of vegetation structure and composition.

\begin{tabular}{|c|c|c|c|c|c|c|c|c|c|c|c|c|}
\hline \multirow[t]{2}{*}{ Source } & \multicolumn{3}{|c|}{$\begin{array}{l}\text { Functional group } \\
\text { abundance }\end{array}$} & \multicolumn{3}{|c|}{ Livestock type } & \multicolumn{3}{|c|}{ Interaction } & \multicolumn{3}{|c|}{ Model } \\
\hline & $\mathrm{SS} \%$ & $\mathrm{~F}$ & $P$ & $\mathrm{SS} \%$ & $\mathrm{~F}$ & $P$ & $\mathrm{SS} \%$ & $\mathrm{~F}$ & $P$ & $\mathrm{SS} \%$ & $\mathrm{~F}$ & $P$ \\
\hline$\alpha$-diversity (\# species) & 17.9 & 8.0 & $<0.01$ & 7.4 & 1.7 & 0.205 & 7.7 & 1.7 & 0.194 & 33.1 & 3.0 & $<0.05$ \\
\hline Vegetation cover $(\%)$ & 4.9 & 1.6 & 0.21 & 4.7 & 0.8 & 0.462 & 1.2 & 0.2 & 0.812 & 10.8 & 0.7 & 0.608 \\
\hline AG biomass stock & 2.7 & 1.2 & 0.286 & 7.3 & 1.6 & 0.221 & 20.8 & 4.5 & $<\mathbf{0 . 0 5}$ & 30.9 & 2.7 & $<0.05$ \\
\hline BG biomass stock & 0.6 & 0.2 & 0.661 & 4 & 0.6 & 0.533 & 2.3 & 0.4 & 0.694 & 6.9 & 0.4 & 0.814 \\
\hline AG biomass $\%$ & 1.9 & 0.8 & 0.373 & 7.8 & 1.7 & 0.202 & 21.4 & 4.7 & $<0.05$ & 31.1 & 2.7 & $<0.05$ \\
\hline BG biomass \% & 0.3 & 0.1 & 0.774 & 4.2 & 0.7 & 0.544 & 2.5 & 0.4 & 0.069 & 7 & 0.5 & 0.241 \\
\hline AG nitrogen pool & 1.1 & 0.5 & 0.491 & 10.5 & 2.3 & 0.118 & 19.9 & 4.4 & $<\mathbf{0 . 0 5}$ & 31.5 & 2.8 & $<0.05$ \\
\hline BG nitrogen pool & 4.4 & 1.5 & 0.234 & 2.5 & 0.4 & 0.667 & 3.5 & 0.6 & 0.561 & 10.4 & 0.7 & 0.631 \\
\hline AG nitrogen $\%$ & 0.4 & 0.2 & 0.781 & 11.2 & 2.5 & 0.232 & 20.6 & 646 & $<0.05$ & 32.2 & 2.9 & $<0.05$ \\
\hline BG nitrogen $\%$ & 0.2 & 0.1 & 0.822 & 2.6 & 0.4 & 0.744 & 3.8 & 0.6 & 0.224 & 6.5 & 0.4 & 0.578 \\
\hline
\end{tabular}

${ }^{\mathrm{a}} \mathrm{SS} \%=\%$ of sum of squares Type $1, \mathrm{AG}=$ aboveground, $\mathrm{BG}=$ belowground, $\%=$ percentage of the ungrazed control.

Analysis of variance confirmed a significant effect of the interaction of functional group abundance and livestock type on the aboveground biomass (but not the belowground biomass) in the grazed pastures (ca. $20 \%$ of variance explained by the interaction, $P<0.05$, Table 2.3 ). Cattle-grazing reduced AGB in the diverse pastures to a much larger extent (to $20 \%$ of the control) than the sheep and co-grazed treatments (to $56 \%$ and $52 \%$, respectively, Table 2.4). In the grass-dominated pastures, the reduction of aboveground biomass by cattle and cograzing was similar (ca. $50 \%$ ), while grazing by sheep tended to reduce the biomass to a greater extent in comparison to the control (difference between the treatments not significant).

In contrast to $\mathrm{AGB}$, the percentage of belowground biomass in the grazed plots relative to the control plots was not significantly influenced by livestock type or functional group abundance (Table 2.3). However, the belowground biomass of grass-dominated plots grazed by cattle was about $10 \%$ higher than in the control plots, while sheep stocking led to a reduced root biomass. 
Table 2.4: Percentage of above- and belowground biomass and biomass $\mathrm{N}$ pools of the grazed plots relative to the ungrazed control plots (means $\pm \mathrm{SE}$ ). Different capital letters show significant differences between the functional group treatments of a livestock treatment, different lower-case letters show significant differences between the livestock treatments within a functional group treatment (t-test: $P<0.05, \mathrm{n}=6$ ).

\begin{tabular}{|c|c|c|c|c|c|c|c|c|c|c|c|c|}
\hline & \multicolumn{4}{|l|}{ Cattle } & \multicolumn{4}{|l|}{ Sheep } & \multicolumn{4}{|c|}{ Co-grazed } \\
\hline & Mean & \pm & $\mathrm{SE}$ & & Mean & \pm & $\mathrm{SE}$ & & Mean & \pm & SE & \\
\hline \multicolumn{13}{|c|}{ Aboveground biomass (\%) } \\
\hline Diverse & 19.8 & \pm & 1.4 & $\mathrm{aA}$ & 56.2 & \pm & 7.7 & $\mathrm{bA}$ & 51.6 & \pm & 5.9 & $\mathrm{bA}$ \\
\hline Grass-dominated & 54 & \pm & 9.2 & $\mathrm{aB}$ & 42.5 & \pm & 10.5 & $\mathrm{aA}$ & 49.3 & \pm & 10.6 & $\mathrm{aA}$ \\
\hline \multicolumn{13}{|c|}{ Belowground biomass (\%) } \\
\hline Diverse & 105 & \pm & 14.5 & $\mathrm{aA}$ & 96.5 & \pm & 8.3 & $\mathrm{aA}$ & 94.4 & \pm & 16.9 & $\mathrm{aA}$ \\
\hline Grass-dominated & 110.6 & \pm & 10.1 & $\mathrm{aA}$ & 86.7 & \pm & 15.3 & $\mathrm{aA}$ & 110 & \pm & 17.2 & $\mathrm{aA}$ \\
\hline \multicolumn{13}{|c|}{ Aboveground nitrogen (\%) } \\
\hline Diverse & 23.2 & \pm & 1.9 & $\mathrm{aA}$ & 75.7 & \pm & 11.3 & $\mathrm{bA}$ & 62.8 & \pm & 9 & $\mathrm{bA}$ \\
\hline Grass-dominated & 61.4 & \pm & 6.4 & $\mathrm{aB}$ & 51.7 & \pm & 16 & $\mathrm{aA}$ & 59.4 & \pm & 12.1 & $\mathrm{aA}$ \\
\hline \multicolumn{13}{|c|}{ Belowground nitrogen (\%) } \\
\hline Diverse & 106.6 & \pm & 14.5 & $\mathrm{aA}$ & 98.1 & \pm & 8.5 & $\mathrm{aA}$ & 90.5 & \pm & 14.2 & $\mathrm{aA}$ \\
\hline Grass-dominated & 99.6 & \pm & 10.9 & $\mathrm{aA}$ & 84.7 & \pm & 13.6 & $\mathrm{aA}$ & 104 & \pm & 13.6 & $\mathrm{aA}$ \\
\hline
\end{tabular}

\subsubsection{Biomass nitrogen pools}

The nitrogen pools in aboveground biomass ranged between 1.1 and $3.5 \mathrm{~g} \mathrm{~m}^{-2}$; they were significantly influenced by the interaction of livestock type and functional group abundance (Table 2.3). In the diverse pastures, the lowest biomass $\mathrm{N}$ pools occurred in plots grazed by cattle, in the grass-dominated pastures in plots grazed by sheep (Figure 2.2). Sheepgrazing reduced the nitrogen pool more in grass-dominated pastures than in diverse pastures (Table 2.4). As for belowground biomass, the nitrogen pool contained in the roots did not differ significantly from that in the control plots (Table 2.4). When the aboveground $\mathrm{N}$ pool is expressed as percentage of the control, a significant influence of the functional group abundance $\mathrm{x}$ livestock type interaction was visible (Table 2.3). This influence was missing for the belowground $\mathrm{N}$ pool expressed relative to the control. 

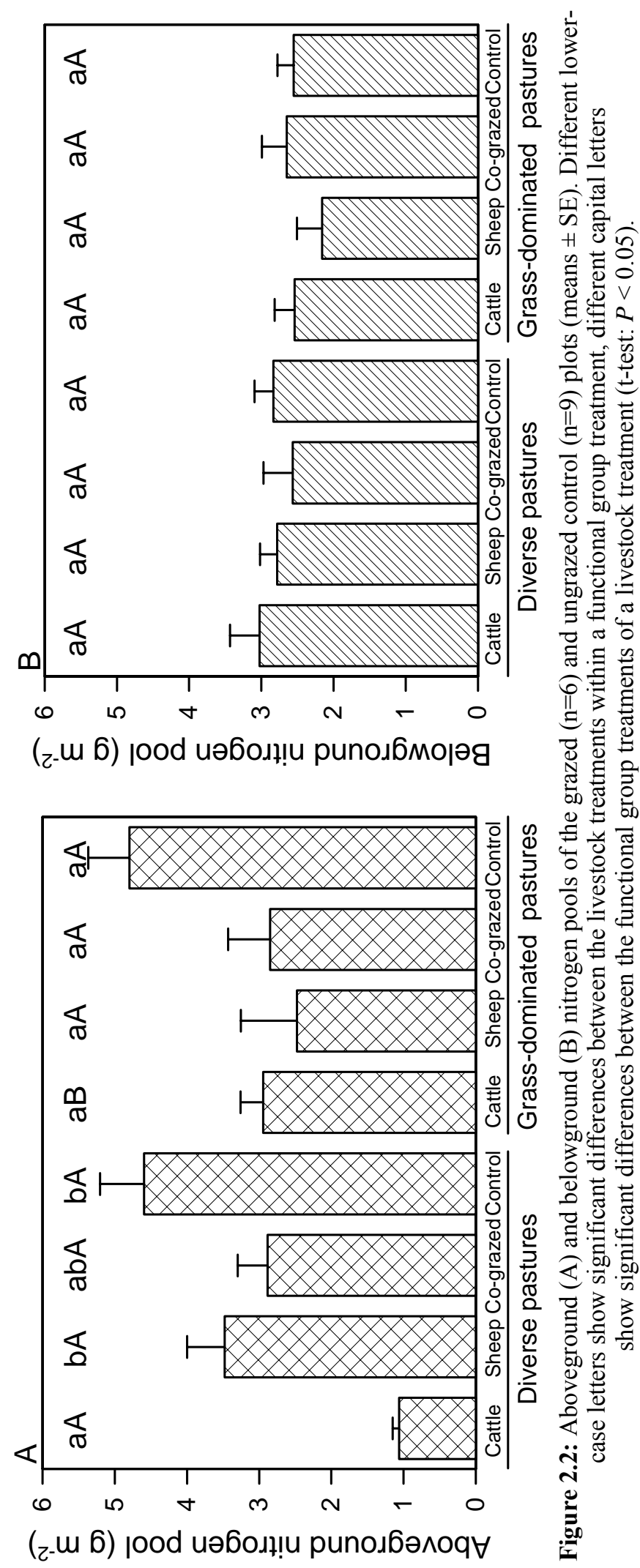


\subsection{Discussion}

\subsubsection{Livestock type effects on aboveground biomass removal}

In our study, cattle and sheep grazing with a similar livestock biomass per hectare led to different AGB reductions but the livestock type effect depended on the structure of the pasture community. This result is consistent with the general perception of the grazing behaviour of the two animals, with sheep typically grazing more selectively on legumes and non-legume herbs, while cattle tend to graze less specifically on herbs and also grasses (Ellis et al. 1976, Armstrong et al. 1997, Rutter 2010). Because sheep extract the plant mass with their teeth while cattle use their tongue, the former are able to remove biomass closer to the ground surface than cattle (Grant et al. 1985). Sheep pastures are, therefore, often shorter in stature than cattle pastures, but plant height depends on several other factors as well, notably livestock density, plant species composition and soil fertility. Furthermore, Armstrong et al. (1997) assume that the requirement for plant biomass consumption per live weight increases with the increasing body size of the livestock suggesting a need for higher fodder intake in the case of cattle.

Our experiment with two treatments differing in functional group abundance produced evidence that livestock type effects are largely dependent on the structural properties of the pasture, because cattle and sheep grazing led to contrasting AGB reductions in 'diverse' and 'grass-dominated' plots. In the latter with only very few legumes and other herbs, cattle reduced AGB significantly less than did the same livestock regime in diverse pasture plots with more herbs. In contrast to the diverse pastures, the greatest AGB reduction was observed under sheep and not under cattle grazing in the grass-dominated pastures. The apparently higher biomass removal by sheep might be a consequence of the reduced percentage of N-rich legume and non-legume herb biomass in this treatment which resulted in larger overall biomass consumption. In general, cattle are used to foliage of lower nutritive quality (Illius \& Gordon 1987, Dumont et al. 1995), while sheep diets usually contain higher protein concentrations than cattle diets (Van Dyne \& Heady 1965). In the grass-dominated plots with low percentage of protein-richer herbs, sheep could not selectively graze on N-rich legumes and non-legume herbs. The opportunity for fodder selection, however, is important for livestock welfare (Villalba et al. 2010, Rutter 2010) and, thus, the lack of choice might have led to higher overall consumption. 
While this causal chain may explain the tendency for a greater AGB reduction by sheep grazing as compared to cattle grazing in the grass-dominated plots, it offers no explanation for the smaller biomass reduction in grass-dominated as compared to diverse pastures by cattle grazing. The possible reason for the decreased biomass intake by cattle could be a higher fibre content in the grasses compared to herbs and legumes: a higher amount of fibre in the diet is known to decrease the daily dry matter intake of cattle (Harris 1992, Allen 2000). However, this assumption needs to be proven by qualitative analyses of the diet.

The biomass nitrogen pools were not as strongly reduced by grazing as the aboveground biomass stocks when compared to the control plots. This is due to decreased aboveground $\mathrm{C} / \mathrm{N}$ ratios in the grazed plots compared to the control plots (t-test: $P<0.0001$, data not shown). Increases in foliar $\mathrm{N}$ concentration after partial defoliation have been observed in many grassland studies (e. g., Jaramillo \& Detling 1988, Burke et al. 1998, Bakker et al. 2009). Such a compensation reaction through $\mathrm{N}$ enrichment in the regrowing shoots should be more prominent in plots rich in legumes. As expected from the less selective grazing behaviour of cattle as compared to sheep (Ellis et al. 1976, Armstrong et al. 1997), cattle grazing on diverse pastures tended to increase the nitrogen concentration of the biomass more than the other livestock treatments by increasing the relative amount of herbs and legumes in the biomass.

\subsubsection{Belowground response to different livestock types}

Aboveground defoliation by livestock grazing has been found to result in variable responses of the plants' belowground biomass (Milchunas \& Laurenroth 1993) depending on the site conditions, the type of grassland community, the grazing regime and the time span considered. Increases in root biomass, or at least in root:shoot ratio, upon grazing are likely to occur if plants are able to restore their leaf area and photosynthetic capacity trough increased C allocation to the renewal of shoots (Tomanek \& Albertson 1957, Holland \& Detling 1990), or over time because plant species are increasingly replaced by species with inherently larger root:shoot ratios that are less sensitive to defoliation. Such a species turnover can increase belowground biomass in the long term as has been observed, for example, in alpine meadows when grazing intensity increased (Gao et al. 2008). Alternatively, species may be unable to sufficiently compensate the losses of biomass which leads inevitably to reductions in root biomass (Isbell \& Wilsey 2011). In our study, we detected no significant difference in the 
absolute amount of root biomass after two years in the three different grazing regimes and also in comparison to the ungrazed control. Remarkably, cattle grazing in the diverse pastures and sheep grazing in the grass-dominated pastures both resulted in a more than $50 \%$ reduction in aboveground biomass but did not affect the amount of BGB. Because the species of this pasture are in most cases long-lived with a life expectancy of many years to decades, it may well be that adaptations in the amount of root biomass produced and in R:S ratio as a response to grazing may take longer time spans than the two years elapsed in our experiment (Dumont et al. 2011, but see Isbell \& Wilsey 2011).

\subsubsection{Conclusions}

Grazing with cattle or sheep or a mixture of the two can result in significantly different reductions in aboveground biomass and aboveground $\mathrm{N}$ pools in temperate pastures. More important, the specific effects of cattle or sheep on biomass removal and plant $\mathrm{N}$ content are modified by the functional group abundance in the pasture as well. Within a given functional group treatment, pastures grazed either by cattle or sheep differed significantly with respect to plant functional group abundance in the residual biomass. The interaction between livestock type and functional group abundance of the pasture has to be considered when balanced grazing regimes with positive effects on pasture diversity, vegetation cover and also stand $\mathrm{N}$ pools are to be selected.

\subsection{References}

Allen, M.S. (2000) Effects of diet on short-term regulation of feed intake by lactating dairy cattle. Journal of Dairy Science 83, 1598-1624.

Allen, V., Batello, C., Berretta, E., Hodgson, J., Kothmann, M., Li, X., Mclvor, J., Milne, J., Morris, C., Peeters, A. \& Sanderson, M. (2011) An international terminology for grazing lands and grazing animals. Grass and Forage Science 66, 2-28.

Armstrong, R.H., Grant, S.A., Common, T.G. \& Beattie, M.M. (1997) Controlled grazing studies on Nardus grassland: effects of between tussock sward height and species of grazer on diet selection and intake. Grass and Forage Science 52, 219-231.

Bakker, E.S., Knops, J.M.H., Milchunas, D.G., Ritchie, M.E. \& Olff, H. (2009) Cross-site comparison of herbivore impact on nitrogen availability in grasslands: the role of plant nitrogen concentration. Oikos 118, 1613-1622.

Bonachela, S. (1996) Root growth of triticale and barley grown for grain or for forage-plus-grain in a Mediterranean climate. Plant and Soil 183, 239-251. 
Burke, I.C., Lauenroth, W.K., Vinton, M.A., Hook, P.B., Kelly, R.H., Epstein, H.E., Aguiar, M.R., Robles, M.D., Aguilera, M.O., Murphy, K.L. \& Gill, R.A. (1998) Plant-soil interactions in temperate grasslands. Biogeochemistry 42, 121-143.

Dierschke, H. \& Briemle, G. (2002) Kulturgrasland. Ulmer Verlag, Stuttgart.

Dumont, B., Dhour, P. \& Petit, M. (1995) The usefulness of grazing tests for studying the ability of sheep and cattle to exploit reproductive patches of pastures. Applied Animal Behaviour Science 45, 79-88.

Dumont, B., Carrere, P., Ginane, C., Farruggia, A., Lanore, L., Tardif, A., Decuq, F., Darsonville, O. \& Louault, F. (2011) Plant-herbivore interactions affect the initial direction of community changes in an ecosystem manipulation experiment. Basic and Applied Ecology 12, 187-194.

Ellenberg, H. \& Leuschner, CH. (2010) Vegetation Mitteleuropas mit den Alpen. (6 $6^{\text {th }}$ ed.) Ulmer Verlag, Stuttgart.

Ellis, J.E., Wiens, J.A., Rodell, C.F. \& Anway, J.C. (1976) Conceptual-model of diet selection as an ecosystem process. Journal of Theoretical Biology 60, 93-108.

Gao, Y.H., Luo, P., Wu, N., Chen, H. \& Wang, G.X. (2008) Impacts of grazing intensity on nitrogen pools and nitrogen cycle in an alpine meadow on the eastern Tibetan plateau. Applied Ecology and Environmental Research 6, 69-79.

Gass, P. \& Oertli, J.J. (1980) Durchwurzelungsvergleich zwischen Fettwiese und angrenzender Brachwiese. Zeitschrift für Pflanzenernährung und Bodenkunde 143, 208-214.

Grant, S.A., Suckling, D.E., Smith, H.K., Torvell, L., Forbes, T.D.A. \& Hodgson, J. (1985) Comparative studies of diet selection by sheep and cattle - the Hill Grasslands. Journal of Ecology 73, 987-1004.

Harris, R. (1992) The importance of fiber in feeding dairy cattle. Dairy production guide Circular 594, Fact sheet DS 40.

Holland, E.A. \& Detling, J.K. (1990) Plant-response to herbivory and belowground nitrogen cycling. Ecology 71, 1040-1049.

Illius, A.W. \& Gordon, I.J. (1987) The allometry of food-intake in grazing ruminants. Journal of Animal Ecology 56, 989-999.

Isbell, F.I. \& Wilsey, B.J. (2011) Increasing native, but not exotic, biodiversity increases aboveground productivity in ungrazed and intensely grazed grasslands. Oecologia 165, 771-781.

Jackson, R.B., Canadell, J., Ehleringer, J.R., Mooney, H.A., Sala, O.E. \& Schulze, E.D. (1996) A global analysis of root distributions for terrestrial biomes. Oecologia 108, 389-411.

Jaramillo, V.J. \& Detling, J.K. (1988) Grazing history, defoliation, and competition - Effects on shortgrass production and nitrogen accumulation. Ecology 69, 1599-1608.

Klapp, E. (1971) Wiesen und Weiden: Eine Grünlandlehre. ( $4^{\text {th }}$ ed.) Parey-Verlag, Berlin/Hamburg.

Krahulec, F., Skálová, H., Herben, T., Hadincová, V., Wildová.R. \& Pecháčková, S. (2001) Vegetation changes following sheep grazing in abandoned mountain meadows. Applied Vegetation Science 4, 97-102.

Krause, B., Culmsee, H., Wesche, K., Bergmeier, E. \& Leuschner, C. (2011) Habitat loss of floodplain meadows in north Germany since the 1950s. Biodiversity and Conservation 20, 2347-2364. 
Liu, X.Z. \& Huang, B.R. (2002) Mowing effects on root production, growth, and mortality of creeping bentgrass. Crop Science 42, 1241-1250.

Milchunas, D.G. \& Lauenroth, W.K. (1993) Quantitative effects of grazing on vegetation and soils over a global range of environments. Ecological Monographs 63, 327-366.

Patty, L., Halloy, S.R.P., Hiltbrunner, E. \& Körner, C. (2010) Biomass allocation in herbaceous plants under grazing impact in the high semi-arid Andes. Flora 205, 695-703.

Richards, J.H. (1984) Root-growth response to defoliation in 2 Agropyron bunchgrasses - Field observations with an improved root periscope. Oecologia 64, 21-25.

Rueda, M., Rebollo, S. \& Rodriguez, M.A. (2010) Habitat productivity influences root mass vertical distribution in grazed Mediterranean ecosystems. Acta Oecologica-International Journal of Ecology 36, 377-382.

Rutter, S.M. (2010) Review: Grazing preferences in sheep and cattle: Implications for production, the environment and animal welfare. Canadian Journal of Animal Science 90, 285-293.

Seither, M., Petersen, U., Wrage, N. \& Isselstein, J. (2010) Effect of mono- and mixed grazing of cattle and sheep on grassland diversity patterns. Grassland Science in Europe 15, 755-757.

Speidel, B. \& Weiss, A. (1972) Zur ober- und unterirdischen Stoffproduktion einer Goldhaferwiese bei verschiedener Düngung. Angewandte Botanik 46, 75-93.

Tasser, E. \& Tappeiner, U. (2002) Impact of land use changes on mountain vegetation. Applied Vegetation Science 5, 173-184.

Tomanek, G.W. \& Albertson, F.W. (1957) Variations in cover, composition, production, and roots of vegetation on 2 prairies in Western Kansas. Ecological Monographs 27, 267-281.

Van Dyne, G.M. \& Heady, H.F. (1965) Dietary chemical composition of cattle and sheep grazing in common on a dry annual range. Journal of Range Management 18, 78-86.

Villalba, J.J., Provenza, F.D. \& Manteca, X. (2010) Links between ruminants' food preference and their welfare. Animal 4, 1240-1247. 



\title{
CHAPTER 3
}

The diversity-productivity relationship in permanent grasslands: negative diversity effect, dominant influence of management regime

\author{
Laura Rose, Christoph Leuschner
}




\subsection{Abstract}

Agricultural intensification has transformed most grasslands of Central Europe from extensive to highly intensive management during the last 50 years, resulting in large reductions of species diversity. This impoverishment has raised concern whether ecosystem functions have been affected as well. A positive diversity effect on productivity was found in experiments with synthetic grasslands but was rarely confirmed in semi-natural grasslands in the field.

We conducted a three-factorial experiment (fertilization, mowing frequency, diversity; $\mathrm{n}=6$ ) in a permanent grassland to disentangle effects of management intensity and diversity on aboveground biomass (AGB), fine root biomass (FRB) and root distribution patterns. Selective herbicides were applied to increase the diversity gradient across the plots.

While fertilization had a strong positive effect on AGB and the cutting frequency only a minor one, AGB was negatively related to species richness.

Root biomass and distribution patterns gave no indication of belowground complementary resource use to be a relevant force for productivity.

The N-driven productivity increase since the 1950s is by far more influential on aboveground productivity than any positive diversity effect, which was not detectable in this permanent grassland. Field manipulation studies in mature communities are needed to understand the productivity-diversity relationship in grasslands under changing land use. 


\subsection{Introduction}

For centuries, managed grasslands have belonged to the most species-rich plant communities of Central Europe, harbouring roughly 1000 higher plant species, or a third of the indigenous flora (Ellenberg \& Leuschner 2010). In the course of agricultural intensification since the 1950/60s, a large-scale transformation of the grassland from extensive to highly intensive management with high fertilizer inputs and frequent mowing has taken place in most parts of Central and Western Europe (e.g., Krahulec et al. 2001, Tasser \& Tappeiner 2002, Krause et al. 2011). In the overwhelming majority of grassland communities, significant and often large reductions in plant species diversity have been recorded in the second half of the $20^{\text {th }}$ century (Sala et al. 2000, Kahmen et al. 2002). This general decline in plant diversity has raised concern whether the dramatic impoverishment of temperate grasslands has negatively affected ecosystem functions and services (Tilman \& Downing 1994, Schmid et al. 2001, Hooper et al. 2005).

Land-use intensification maximizes the productivity of grasslands by high fertilizer inputs and increases the disturbance intensity. Both factors should reduce plant diversity either through processes leading to competitive exclusion or by an unfavourable mechanical disturbance regime (Tilman 1993, Zechmeister et al. 2003, Gross et al. 2009). Theoretical studies suggest that land-use intensification will be the key driver of future biodiversity changes in terrestrial ecosystems (Sala et al. 2000). Thus, understanding the mutual relationship between land-use change, biodiversity and ecosystem functioning is critical for balancing the partly conflicting goals of high yields, conservation of biodiversity and maintenance of ecosystem functions in agricultural landscapes.

In the past, much research has focused on the relationship between biodiversity and ecosystem functioning, with an emphasis on the relation between plant diversity and productivity or ecosystem functioning (e.g., Naeem et al. 1994, Tilman et al. 1996, Hooper \& Vitousek 1997, Hector et al. 1999, Roscher et al. 2005, Hector \& Bagchi 2007, Isbell et al. 2011). Biodiversity experiments with artificial assemblages of grassland species in most cases showed productivity increases with increasing numbers of species, which may be explained by niche differentiation and biotic interactions leading to increased resource use (Tilman et al. 1996, Hector 2001, Loreau \& Hector 2001, van Peer et al. 2004, Isbell et al. 2009). However, these findings were criticised because they seem to have little relevance for patterns found in natural or semi-natural grassland communities (Grime 1997, Huston et al. 2000, Bardgett \& 
Wardle 2010), where, in most cases, no or even negative diversity-productivity relationships are observed (Thompson et al. 2005, Grace et al. 2007). Similarly, species reduction experiments in natural systems found production to be rather insensitive to decreases in diversity (Smith \& Knapp 2003, Suding et al. 2006). Over the whole range of fertility conditions found in nature, the dependence of grassland biomass and productivity on plant species richness is best described by a hump-shaped curve with most communities of modern agricultural landscapes being positioned on the right (descending) leg of the curve (Grime 1973, Oomes 1992).

Several causes have been discussed for the little relevance of biodiversity experiments with artificial assemblages for natural communities, among them the immaturity of sown communities (e.g. Thompson et al. 2005), the fact that the importance of niche complementarity may be reduced in species-richer stands by other biotic interactions such as competition (Yachi \& Loreau 2007), and the artificial maintenance of dominance hierarchies by frequent weeding (Huston et al. 2000, Bardgett \& Wardle 2010). It has also been argued that discrepancies between results obtained from artificial and semi-natural communities may partly be caused by considering different spatial scales (e.g., Chase \& Leibold 2002, Gross et al. 2009). While most field studies in natural grasslands investigated the diversityproductivity relationship in larger plots (e.g. Oomes 1992, Kahmen et al. 2005, Grace et al. 2007) and considered stands with contrasting soil and/or climate conditions, complementary resource use and facilitation should be more relevant at the small, plant-neighbourhood scale (Gross et al. 2009).

Given that the key motivation for investigating the functional role of biodiversity is concern about global diversity loss, the severest shortcoming of biodiversity experiments with artificial grassland assemblages is that they were not designed to address the dramatic landuse change that is currently reshaping the agricultural landscape. Experiments that treat management as invariant, do not address the major driver of species loss and may be of theoretical interest, but are of low relevance for conservation issues and management optimization. We conclude that there is a need for studies on the biodiversity-ecosystem function relationship in established managed grasslands with a long continuity.

In this study, we examined species diversity, above- and belowground biomass, aboveground productivity and root distribution in an upland grassland with more than 200 years of continuous management. By applying $\mathrm{N}$ fertilizer $\left(180 \mathrm{~kg} \mathrm{ha}^{-1} \mathrm{yr}^{-1} \mathrm{vs}\right.$. no fertilization) and mowing treatments (three vs. one cutting per season) we simulated the transformation from low- to high-intensity grassland management in the past 50 years in 
Central Europe. In order to enhance the variability of species diversity in the studied grassland, we introduced a third treatment by applying selective herbicides that reduced the abundance of either monocots or dicots in selected study plots and thus altered functional group evenness and diversity.

We tested the following hypotheses: (i) Fertilization is the dominant factor determining biomass, root/shoot ratio and productivity, (ii) species richness is a subordinate factor influencing biomass and productivity at a small scale, and (iii) more species-rich stands explore the subsoil more intensively due to belowground niche complementarity.

\subsection{Material and methods}

\subsubsection{Study site and weather conditions during the experiment}

Our study took place within the framework of the 'GrassMan' experiment, an interdisciplinary replicated field experiment on the role of plant diversity for ecosystem functions in differently managed permanent meadow plots (Petersen et al. 2011). Plots were installed at the Experimental Farm Relliehausen, Solling Mountains, Central Germany $\left(51^{\circ} 44^{\prime}\right.$ $\mathrm{N}, 9^{\circ} 32^{\prime} \mathrm{E}, 490 \mathrm{~m}$ a.s.1.) in 2008. The soils are haplic Cambisols with a mean $\mathrm{pH}_{\mathrm{H}_{2} \mathrm{O}}$ of 5.34.

The vegetation is a montane, nutrient-poor, mesic-moist to moist grassland community of the Lolio-Cynosuretum association. The most abundant grass, non-legume herb and legume species are Agrostis capillaris L., Rumex acetosa L. and Trifolium repens L., respectively. In previous decades, the site has been used for extensive cattle grazing; the continuity of the grassland can be traced back over more than 100 years (Preußische Landesaufnahme 1905) and it is known to have been grazed at least since the late $18^{\text {th }}$ century. Thus, it can be classified as 'historically old' in the sense of Waesch (2003) and Ellenberg \& Leuschner (2010).

Mean annual temperature and precipitation are $6.9^{\circ} \mathrm{C}$ and $1031 \mathrm{~mm}$ (DWD 1961-1990). The mean air temperature during the growing season of the study year (April - September 2009) was $14.3^{\circ} \mathrm{C}$ and total precipitation during this period was $388 \mathrm{~mm}$. Total global radiation in the measurement period was $2572 \mathrm{MJ} \mathrm{m}^{-2}$ (monthly means and sums are given in Table 3A.1). 


\subsubsection{Experimental design}

The full-factorial design of the study includes two cutting frequencies and two NPKfertilization levels that were combined with a manipulation of plant diversity in the grassland plots using herbicides, resulting in three diversity levels. The 12 different treatments were replicated six times leading to 72 plots of $15 \mathrm{~m} \times 15 \mathrm{~m}$ size arranged in a Latin rectangle with six rows and six doubled columns. Half of the plots were cut once a year in July (C1: lowintensity mowing regime) and half of them cut three times in May, July, and September (2008 in November) (C3: high-intensity mowing regime). Half of the plots were NPK-fertilized $\left(\mathrm{NPK}+, 180 \mathrm{~kg} \mathrm{~N} \mathrm{ha}^{-1} \mathrm{yr}^{-1}\right.$ applied as a mix of $\mathrm{NH}_{4} \mathrm{NO}_{3}$ and $\mathrm{CaCO}_{3}, 74: 26 \mathrm{wt} / \mathrm{wt}, 30 \mathrm{~kg} \mathrm{P} \mathrm{ha}^{-1}$ and $107 \mathrm{~kg} \mathrm{~K} \mathrm{ha}^{-1}$ ) and half of them received no fertilizer (NPK-). Site management started in July 2008, in the remaining second half of the summer 2008, the C3 plots were cut twice and only $50 \mathrm{~kg} \mathrm{Nha}{ }^{-1}$ of fertilizer were applied to account for the reduced length of the experimental period (Table 3.1).

Table 3.1: Management procedures conducted at the experimental site in 2008 and 2009. Treatments differ in NPKfertilization (NPK+ / NPK-) and cutting frequency (C1 / C3).

\begin{tabular}{|c|c|c|c|c|c|c|c|c|c|}
\hline & \multicolumn{3}{|l|}{2008} & \multicolumn{6}{|l|}{2009} \\
\hline & $01 / 07$ & $26 / 08$ & $04 / 11$ & $15 / 04$ & $14 / 05$ & $28 / 05$ & $04 / 06$ & $09 / 07$ & $6-8 / 09$ \\
\hline & & 50 & & 90 & & & $30 \mathrm{~kg} \mathrm{P} \mathrm{ha}{ }^{-1}$ & & \\
\hline Treatment & Cutting & $\mathrm{kg} \mathrm{N} \mathrm{ha}^{-1}$ & Cutting & $\mathrm{kg} \mathrm{N} \mathrm{ha}^{-1}$ & Cutting & $\mathrm{kg} \mathrm{N} \mathrm{ha}^{-1}$ & $107 \mathrm{~kg} \mathrm{~K} \mathrm{~h}^{-1}$ & Cutting & Cutting $^{\mathrm{a}}$ \\
\hline NPK-C1 & $x$ & & & & & & & $x$ & $x$ \\
\hline $\mathrm{NPK}+\mathrm{C} 1$ & $\mathbf{x}$ & $\mathbf{x}$ & & $\mathbf{x}$ & & $\mathbf{x}$ & $\mathbf{x}$ & $\mathbf{x}$ & $\mathbf{x}$ \\
\hline NPK-C3 & $\mathbf{x}$ & & $\mathbf{x}$ & & $\mathbf{x}$ & & & $\mathbf{x}$ & $\mathbf{x}$ \\
\hline $\mathrm{NPK}+\mathrm{C} 3$ & $\mathbf{x}$ & $\mathbf{x}$ & $\mathbf{x}$ & $\mathbf{x}$ & $\mathbf{x}$ & $\mathbf{x}$ & $\mathbf{x}$ & $\mathbf{x}$ & $\mathbf{x}$ \\
\hline
\end{tabular}

${ }^{\mathrm{a}}$ The cutting event was combined with the final harvest of the above- and belowground biomass.

To create a gradient in plant species diversity with three diversity levels, one third of the plots was treated with the herbicides Starane and Duplosan KV (active components Fluroxypyr/ Triclopyr and Duplosan KV; both added at a dose of $3 \mathrm{~L} \mathrm{ha}^{-1}$ ) to decrease the cover and abundance of dicots (-Dic), one third was sprayed with the herbicide Select 240 EC (Stähler Int., Stade, Germany; $0.5 \mathrm{~L} \mathrm{ha}^{-1}$ ) to reduce the abundance of monocots (-Mon) and one third was left untreated as a control (Control). Herbicide application took place on July 31, 2008 and led to significant changes in functional group abundances and species richness in May 2009 (Petersen et al. in press): The -Dic treatment resulted in a reduction of herbs and legumes from initially $28 \%$ of the biomass yield to about $8 \%$, while the -Mon treatment reduced the proportion of grasses in the biomass yield from $72 \%$ to about $45 \%$ on the plot scale. Species richness was significantly decreased in the -Dic plots (from 17 to 13 species in relevés of $9 \mathrm{~m}^{2}$ ), while it was unaffected in the plots treated for monocot reduction. Herbicide 
application did not reduce the cover of the sward nor did it increase the abundance of annual species. Further, on the plot scale, no impact of the herbicide treatment on biomass yields was detectable in 2009 (From et al. 2011).

\subsubsection{Vegetation analyses and biomass sampling}

Three subplots $(0.5 \mathrm{~m} \times 0.5 \mathrm{~m})$ were installed at random positions in every plot at $1 \mathrm{~m}$ minimum distance from the plot edge. Before every cutting event, vegetation analyses were conducted in one subplot and the aboveground biomass was clipped by hand to ground level; samples were stored in plastic bags $\left(8^{\circ} \mathrm{C},<7\right.$ days) until sorting into functional groups (i.e. grasses, non-legume herbs and legumes) and litter took place. The species richness was expressed as the number of higher plant species per subplot $\left(0.25 \mathrm{~m}^{2}\right)$. Belowground biomass was accessed by extracting four soil samples per subplot with a soil corer (inner diameter: $3.5 \mathrm{~cm}$ ) to $30 \mathrm{~cm}$ depth after the last harvest between September 10 and September 14. The cores were split into two subsamples (0 - 15 and 15 - $30 \mathrm{~cm}$ depth); roots were cleaned from soil residues using a sieve (mesh size: $0.2 \mathrm{~mm}$ ) and sorted by diameter (fine roots $\leq 2 \mathrm{~mm}$, coarse roots $>2 \mathrm{~mm}$ ). One representative subsample per fine root sample was digitalized on a flatbed-scanner using the software WinRhizo 2005c (Régent Instr., Québec, Canada) to calculate root length and root area.

All plant material was dried $\left(70{ }^{\circ} \mathrm{C}, 80 \mathrm{~h}\right)$ and weighed. The aboveground biomass produced during the investigated growing season was calculated by adding the dry aboveground biomass extracted at the first (C3) and second (C1, C3) cutting to the final September harvest $(\mathrm{C} 1, \mathrm{C} 3)$. This harvesting scheme can quantify the aboveground net primary production only approximately (Lauenroth et al. 2006); consequently, we refer to the harvest data as aboveground biomass (AGB).

After scaling biomass to ground area, we calculated the root:shoot ratio at the last

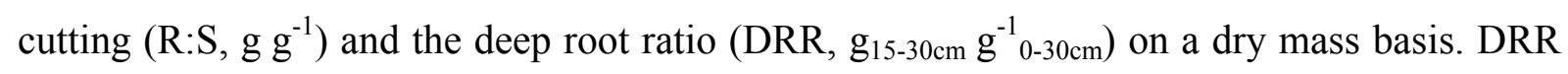
relates the amount of relatively deep-reaching roots to total root mass (Kato et al. 2007) and allows categorizing the vertical distribution of the root system. Specific root length (SRL, $\mathrm{mg}^{-1}$ ) scales fine root biomass to root length and the root area index (RAI, $\mathrm{m}^{2} \mathrm{~m}^{-2}$ ) was obtained by multiplying specific root area with standing fine root biomass. 


\subsubsection{Statistical analyses}

Statistical analyses were performed using the software $\mathrm{R}$ (version 2.13.2, $\mathrm{R}$ Development Core Team 2011) with a significance level of $P \leq 0.05$ throughout.

Linear mixed effects models (LME) were fit for the response variables AGB, FRB, R:S, DRR, SRL and RAI using the lme procedure, library nlme (Pinheiro et al. 2011) to analyse the influences of either small-scale (subplot) species richness or herbicide treatment, each in combination with the two management factors fertilization and cutting frequency. The latter factors were included in the models as fixed effects and either herbicide treatment as a fixed effect or species richness as a covariate. A random structure (Column, Row or Column and Row) was included if it improved the relative goodness of the model fit based on the Akaike Information Criterion (AIC), using the residual maximum likelihood method (REML). The models were tested for heteroscedasticity of the residual variance by graphical inspection. The four root samples collected per subplot were pooled before statistical analysis.

We started with maximal models and simplified them by using the stepAIC function, until the AIC score reached a global minimum following the principal of marginality (i.e. not deleting any non-significant effects present in significant higher-order interactions). The maximum likelihood (ML) method was used during model selection and the models were recalculated with REML and tested again for heteroscedasticity of the residual variance after simplification. Post-hoc Tukey-tests (Bonferroni corrected) were performed to identify differences between treatment means of DRR, which was influenced by a three-fold interaction of the factors herbicide, fertilization and cutting treatment.

The effects of herbicide treatment and management on small-scale species richness were analysed by a mixed effects model including herbicide treatment, fertilization and cutting frequency as fixed effects. After execution of the simplification procedure described above, herbicide treatment was the only source variable remaining in the model. A post-hoc t-test was performed for identifying differences between the three diversity levels in species richness and the percentage of the three functional groups (grasses, herbs and legumes) in the biomass. 


\subsection{Results}

\subsubsection{Herbicide and management effects on small-scale species richness,}

\section{biomass and biomass partitioning}

The number of species per subplot $\left(0.25 \mathrm{~m}^{2}\right)$ ranged between 3 and 12 , with a mean of 7 species. It was neither affected by the cutting frequency nor by fertilization, but significantly altered by herbicide application. Compared to the control plots ( 8 species), the small-scale species richness was significantly increased to 9 species per subplot in the treatment with monocot reduction (-Mon plots), but significantly decreased to 6 species in the -Dic plots (Figure 3.1A). Further, herbicide application significantly altered the relative abundance of the functional groups by decreasing the percentage of herb and legume biomass in the -Dic treatment on the subplot scale from 11 to $3 \%$ and from 5 to $0 \%$, respectively, and by reducing the percentage of grass biomass in the -Mon treatment from 84 to $77 \%$ (Figure 3.1B).
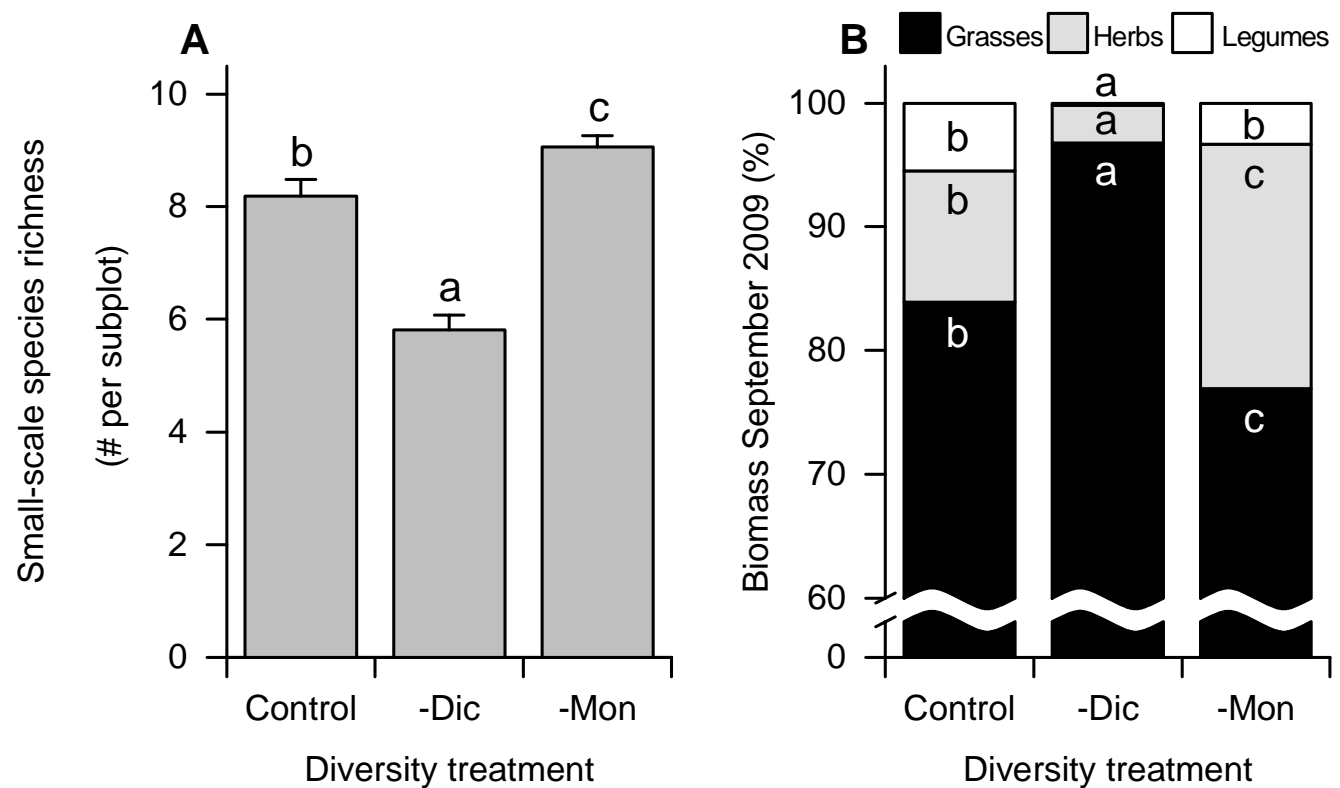

Figure 3.1: Small-scale species richness (A) and relative abundance of functional groups in terms of biomass (B) in the sampled subplots $\left(0.25 \mathrm{~m}^{-2}\right)$ in the three diversity treatments. Different letters indicate significantly different means (t-test, $P<0.05, \mathrm{n}=18$ ). 
Table 3.2: Summary of simplified mixed effects models for all investigated parameters including herbicide treatment $(\mathrm{H})$, cutting frequency and fertilization as fixed effects in initial models. Models were simplified using the AIC score as selection criterion.

\begin{tabular}{lcccccccc}
\hline & Estimate & \pm & $\mathrm{SE}$ & $\mathrm{df}(\mathrm{n})$ & $\mathrm{df}(\mathrm{d})$ & $F$ & $P$ & $\begin{array}{c}\text { Random } \\
\text { structure }\end{array}$ \\
\cline { 2 - 8 } Aboveground biomass & & & & & & & & Row \\
\hline Intercept & 1103.71 & \pm 43.86 & 1 & 62 & 1842.36 & $* * *$ & \\
Herbicide & & & 2 & 62 & 6.98 & $* *$ & \\
$\quad-$ Dic & -2.27 & \pm 40.89 & & & & & \\
$\quad-$ Mon & -133.40 & \pm 40.89 & & & & & \\
NPK+ & 233.05 & \pm 33.39 & 1 & 62 & 48.72 & $* * *$ & \\
C3 & 91.33 & \pm 33.39 & 1 & 62 & 7.48 & $* *$ &
\end{tabular}

Fine root biomass

Block

\begin{tabular}{lllllll}
\hline Intercept & 413.10 & \pm 24.47 & 1 & 66 & 285.04 & $* * *$
\end{tabular}

Root/shoot ratio

Block

\begin{tabular}{lccccccc}
\hline Intercept & 1.50 & \pm & 0.16 & 1 & 65 & 78.82 & $* * *$ \\
NPK + & -0.25 & \pm & 0.09 & 1 & 65 & 7.41 & $* *$
\end{tabular}

Deep root ratio

Block

\begin{tabular}{|c|c|c|c|c|c|c|c|}
\hline Intercept & 0.114 & \pm & 0.019 & 1 & 53 & 597.33 & $* * *$ \\
\hline Herbicide & & & & 2 & 53 & 3.62 & $*$ \\
\hline -Dic & 0.057 & \pm & 0.027 & & & & \\
\hline -Mon & 0.033 & \pm & 0.027 & & & & \\
\hline $\mathrm{NPK}+$ & 0.032 & \pm & 0.027 & 1 & 53 & 1.03 & n.s. \\
\hline $\mathrm{C} 3$ & 0.001 & \pm & 0.027 & 1 & 53 & 0.40 & n.s. \\
\hline Herbicide $\mathrm{x}$ NPK + & & & & 2 & 53 & 3.61 & $*$ \\
\hline -Dic x NPK+ & -0.066 & \pm & 0.038 & & & & \\
\hline -Mon x NPK+ & -0.056 & \pm & 0.038 & & & & \\
\hline Herbicide x C3 & & & & 2 & 53 & 0.66 & n.s. \\
\hline -Dic x C3 & 0.019 & \pm & 0.038 & & & & \\
\hline -Mon x C3 & -0.036 & \pm & 0.038 & & & & \\
\hline $\mathrm{NPK}+\mathrm{x} \mathrm{C} 3$ & -0.055 & \pm & 0.039 & 1 & 53 & 0.04 & n.s. \\
\hline Three-fold interaction & & & & 2 & 53 & 3.55 & $*$ \\
\hline -Dic x NPK+ x C3 & 0.017 & \pm & 0.055 & & & & \\
\hline- Mon $\mathrm{x}$ NPK $+\mathrm{x}$ C3 & 0.136 & \pm & 0.056 & & & & \\
\hline
\end{tabular}

Specific root length

Intercept

$298.92 \pm 16.09$

$63 \quad 345.18 * * *$

Block

Root area index

Block/Row

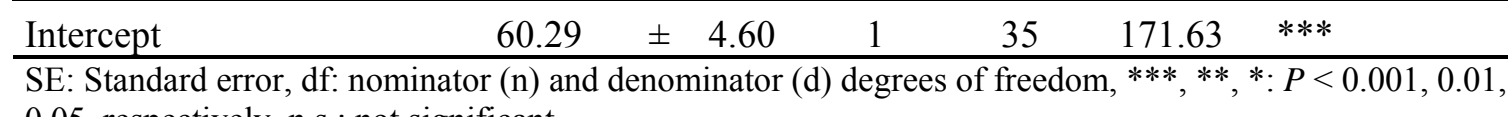
0.05 , respectively, n.s.: not significant. 
The aboveground biomass grown up in the vegetation period 2009 ranged between 835 and $1719 \mathrm{~g} \mathrm{~m}^{-2}$ (mean: $1221 \mathrm{~g} \mathrm{~m}^{-2}$ ). It was significantly influenced by the herbicide treatment, fertilizer application and the cutting frequency (Table 3.2). In detail, the reduction of monocots reduced the aboveground biomass by $133 \mathrm{~g} \mathrm{~m}^{-2}$, while dicot reduction had no effect (Table 3.2). Fertilizer application increased the aboveground biomass on average by about $235 \mathrm{~g} \mathrm{~m}^{-2}$ while a higher cutting frequency (three instead of one cutting) raised AGB by $90 \mathrm{~g} \mathrm{~m}^{-2}$ (Table 3.2, 3.3). Fine root biomass ranged between 237 and $698 \mathrm{~g} \mathrm{~m}^{-2}$ (mean: 413, Table 3.2) and was neither influenced by the herbicide treatment nor by fertilization or altered cutting frequency (Table 3.2). The root:shoot biomass ratio at the September harvest (mean: $1.37 \mathrm{~g} \mathrm{~g}^{-1}$, range 0.49 to 3.27 ) was significantly lower by $0.25 \mathrm{~g} \mathrm{~g}^{-1}$ in fertilized than in unfertilized plots but independent of the cutting frequency (Table 3.2).

\subsubsection{Herbicide and management effects on fine root distribution and morphology}

Most fine root biomass was located in the upper $15 \mathrm{~cm}$ of the soil and on average only $13.7 \%$ (range $4.5-30.9 \%$ ) was found in the lower profile (15 - $30 \mathrm{~cm}$ depth). Linear mixed effects models revealed a significant influence of the three-way interaction between herbicide, fertilization and cutting frequency on the deep root ratio (Table 3.2). DDR differed significantly between fertilized frequently cut plots (no herbicide treatment: NPK $+\mathrm{C} 3 ; 0.09$ ) and the herbicide-treated $-\mathrm{Dic} \times \mathrm{C} 3$ plots $(0.19$; post-hoc Tukey-test).

Specific root length ranged between 141 and $500 \mathrm{~m} \mathrm{~g}^{-1}$ (mean: $299 \mathrm{~m} \mathrm{~g}^{-1}$, Table 3.2) and was not affected by any of the tested explanatory variables. The mean root area index (RAI) of all plots in September 2009 was $60.3 \mathrm{~m}^{2} \mathrm{~m}^{-2}$ (range 29.2 - 136.7); neither management nor the herbicide treatment had a significant effect on RAI (Table 3.2). 


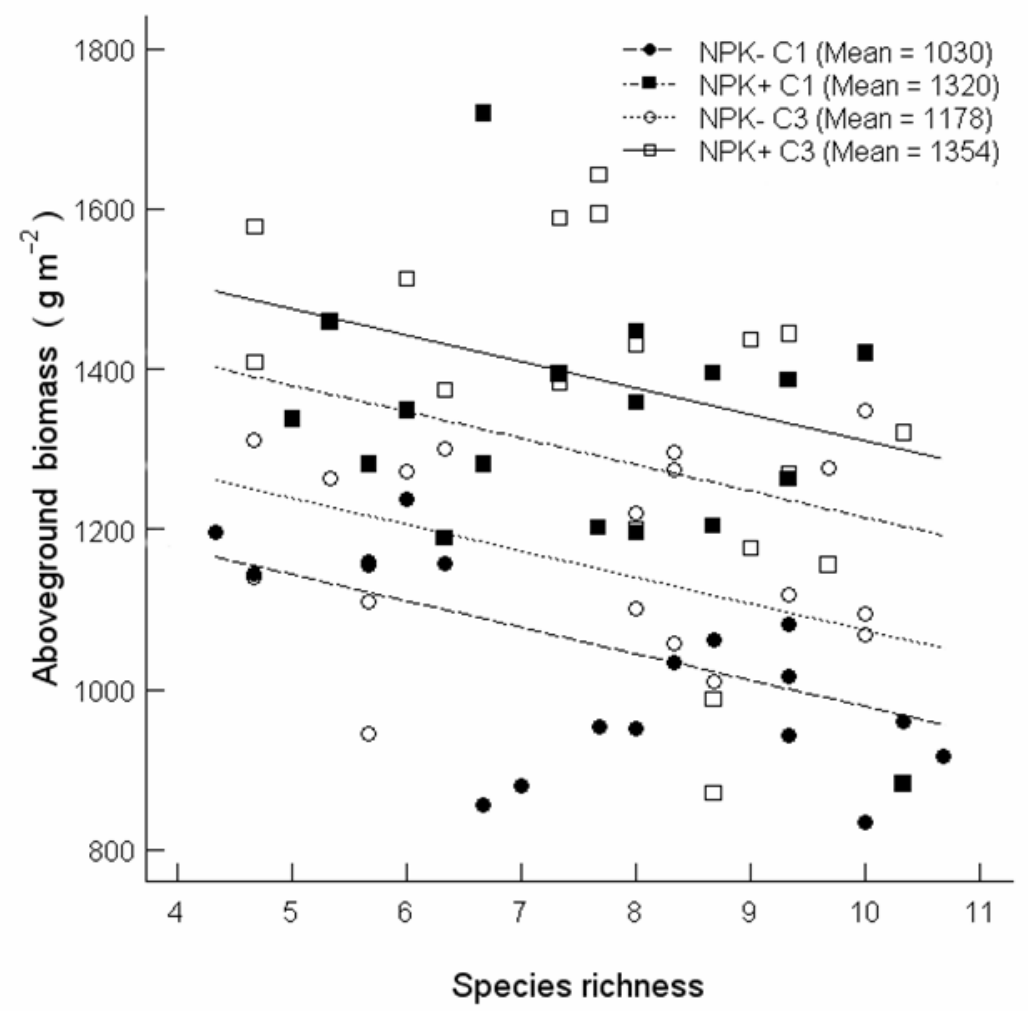

Figure 3.2: Dependence of the aboveground biomass harvested on species richness in the four management treatments. Lines show models predictions (for treatment abbreviations see Table 3.1). $\mathrm{N}=18$ plots per treatment.

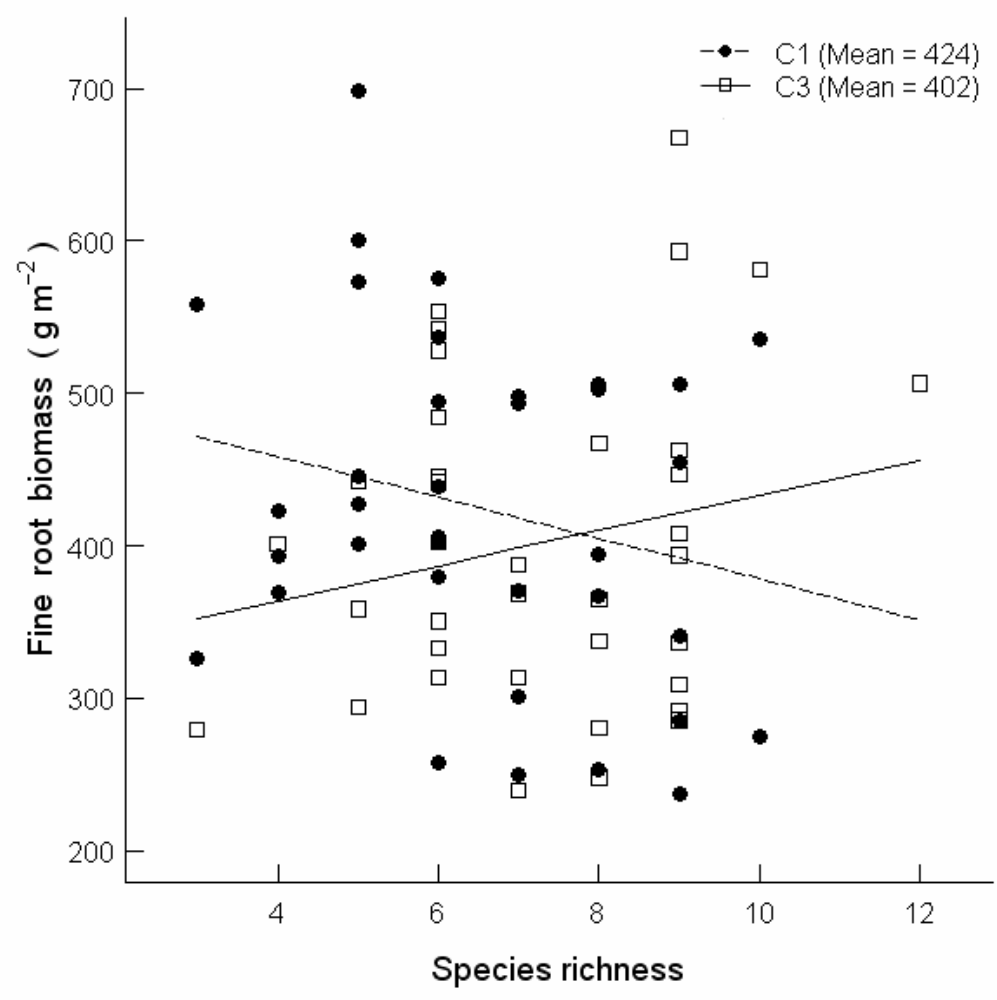

Figure 3.3: Dependence of standing fine root biomass on species richness in the two different cutting treatments. Lines show models predictions (for treatment abbreviations see Table 3.1). $\mathrm{N}=36$ plots per treatment. 
Table 3.3: Summary of simplified mixed effects models for all investigated parameters including cutting frequency and fertilization as fixed effects and species richness as a covariate in initial models. Models were simplified using the AIC score as selection criterion.

\begin{tabular}{lcccccccc}
\hline & & & & & & & $\begin{array}{c}\text { Random } \\
\text { structure }\end{array}$ \\
\cline { 2 - 9 } Abstimate & \pm & $\mathrm{SE}$ & $\mathrm{df}(\mathrm{n})$ & $\mathrm{df}(\mathrm{d})$ & $F$ & $P$ & Row \\
\hline Intercept & 1308.30 & \pm 82.95 & 1 & 63 & 2044.37 & $* * *$ & \\
Species richness & -32.92 & \pm & 9.84 & 1 & 63 & 9.36 & $* *$ & \\
NPK+ & 236.40 & \pm 33.92 & 1 & 63 & 48.53 & $* * *$ & \\
C3 & 94.69 & \pm 33.92 & 1 & 63 & 7.79 & $* *$ &
\end{tabular}

Fine root biomass

Block

\begin{tabular}{lcccccc}
\hline Intercept & 512.03 & \pm 63.73 & 1 & 63 & 298.88 & $* * *$ \\
Species richness & -13.36 & \pm 8.85 & 1 & 63 & 0.11 & n.s. \\
C3 & -194.17 & \pm 87.54 & 1 & 63 & 0.91 & n.s. \\
C3 x Species richness & 24.88 & \pm 12.21 & 1 & 63 & 4.15 & $*$
\end{tabular}

Root/shoot ratio

Block

\begin{tabular}{lccccccc}
\hline Intercept & 1.12 & \pm & 0.24 & 1 & 64 & 80.73 & $* * *$ \\
Species richness & 0.05 & \pm & 0.03 & 1 & 64 & 5.38 & $*$ \\
NPK + & -0.24 & \pm & 0.09 & 1 & 64 & 6.86 & $*$
\end{tabular}

Deep root ratio

\begin{tabular}{lccccccc}
\hline Intercept & 0.178 & \pm & 0.023 & 1 & 63 & 518.91 & $* * *$ \\
Species richness & -0.006 & \pm & 0.003 & 1 & 63 & 3.55 & $(*)$
\end{tabular}

Specific root length

$\begin{array}{ccc}62 & 284.93 & * * * \\ 62 & 6.36 & * \\ & & \\ 34 & 168.08 & * * * \\ 34 & 7.58 & * *\end{array}$

Block

\begin{tabular}{lccccccc}
\hline Intercept & 373.86 & \pm 34.57 & 1 & 62 & 284.93 & $* * *$ \\
Species richness & -10.74 & \pm & 4.26 & 1 & 62 & 6.36 & $*$
\end{tabular}

Root area index

Block/Row

\begin{tabular}{lccccccl}
\hline Intercept & 79.23 & \pm & 8.30 & 1 & 34 & 168.08 & $* * *$ \\
Species richness & -2.74 & \pm & 1.00 & 1 & 34 & 7.58 & $* *$ \\
\hline SE: Stan
\end{tabular}

SE: Standard error, df: nominator (n) and denominator (d) degrees of freedom, $\left.{ }^{* * *},{ }^{* *},{ }^{*},{ }^{*}\right): P<0.001,0.01$, $0.05,0.1$, respectively, n.s.: not significant.

\subsubsection{Effects of species richness on biomass and rooting patterns}

According to the mixed effects models, species richness had a significant negative effect $\left(-33 \mathrm{~g} \mathrm{~m}^{-2}\right.$ per additional species) on the aboveground biomass in 2009 irrespective of the management regime (Figure 3.2, Table 3.3). The fine root biomass in September 2009 was influenced by a significant interaction between species richness and the cutting frequency (Table 3.3). More precisely, the fine root biomass in the $\mathrm{C} 1$ plots was negatively related to species richness (root biomass decreased by $13 \mathrm{~g} \mathrm{~m}^{-2}$ for every additional species), while a 
positive slope was found for plots with three cuttings (increase by $12 \mathrm{~g} \mathrm{~m}^{-2}$ for every additional species, Figure 3.3). The root:shoot ratio in September 2009 showed a significant positive relationship to species richness (Figure 3.4, Table 3.3).

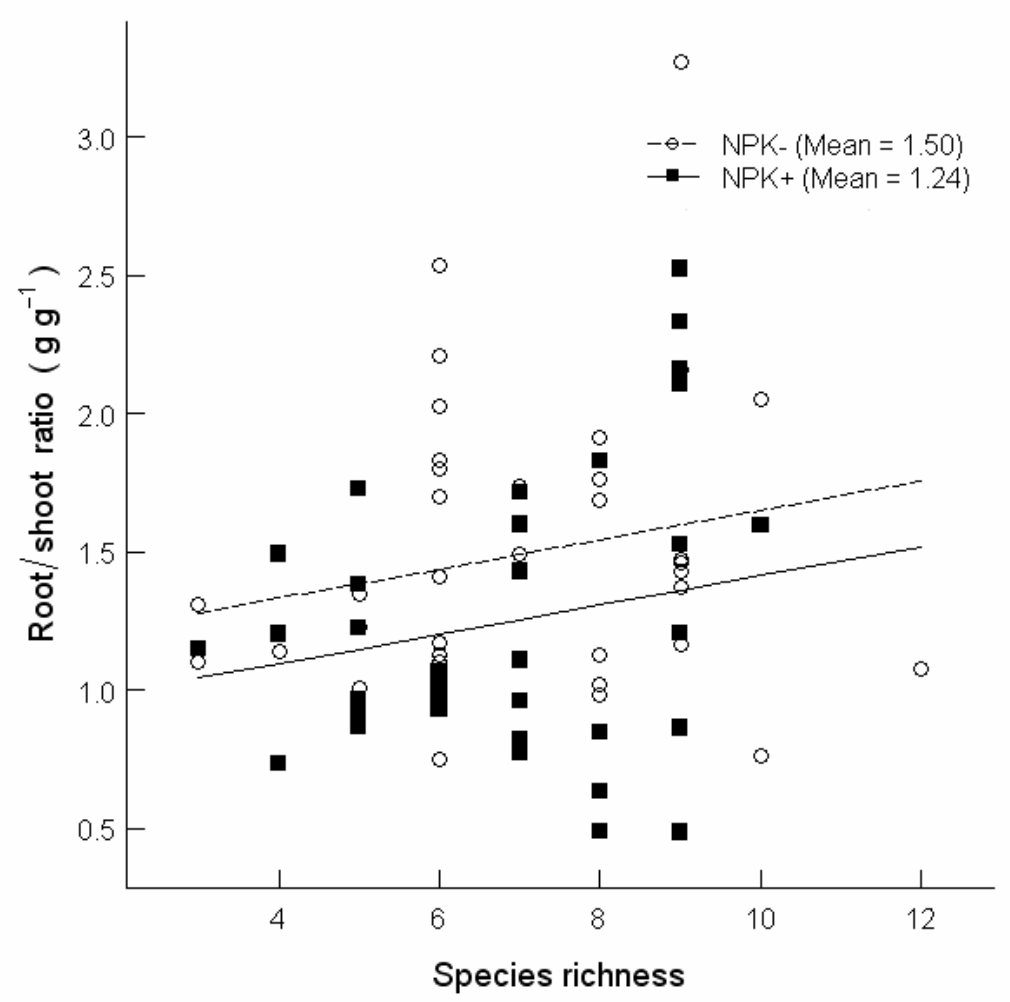

Figure 3.4: Dependence of root/shoot ratio on species richness in the two fertilizer treatments. Lines show models predictions (for treatment abbreviations see Table 3.1). $\mathrm{N}=36$ plots per treatment.

The deep root ratio was only marginally $(P<0.1)$ related to species richness, whereas species-richer plots tended to have shallower root systems. Further, the mixed effects models indicated a significant negative effect of species richness on specific root length irrespective of the fertilizer or cutting treatment (Figure 3.5, Table 3.3). A negative relationship existed between small-scale species richness and root area index (RAI reduction by $2.74 \mathrm{~m}^{2} \mathrm{~m}^{-2}$ for every additional species present; Table 3.3, Figure 3.6). 


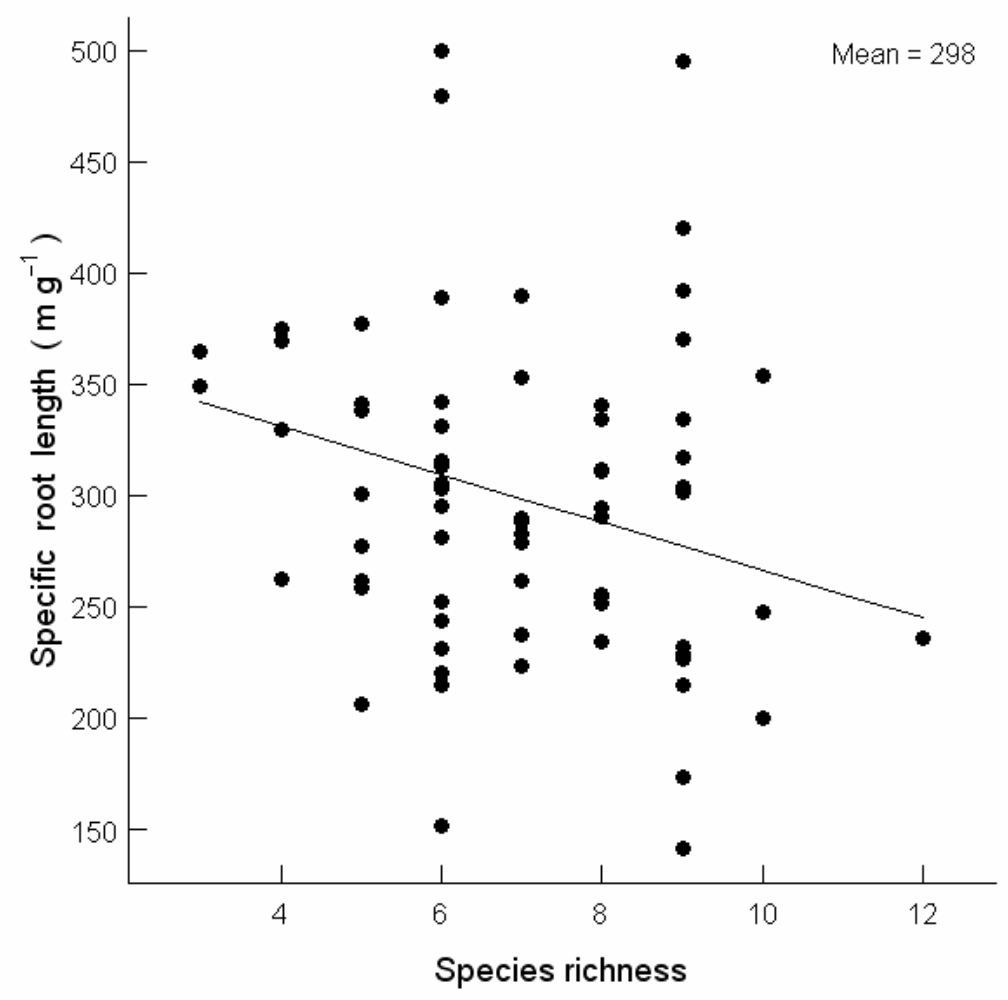

Figure 3.5: Dependence of specific root length on species richness. $N=72$ plots.

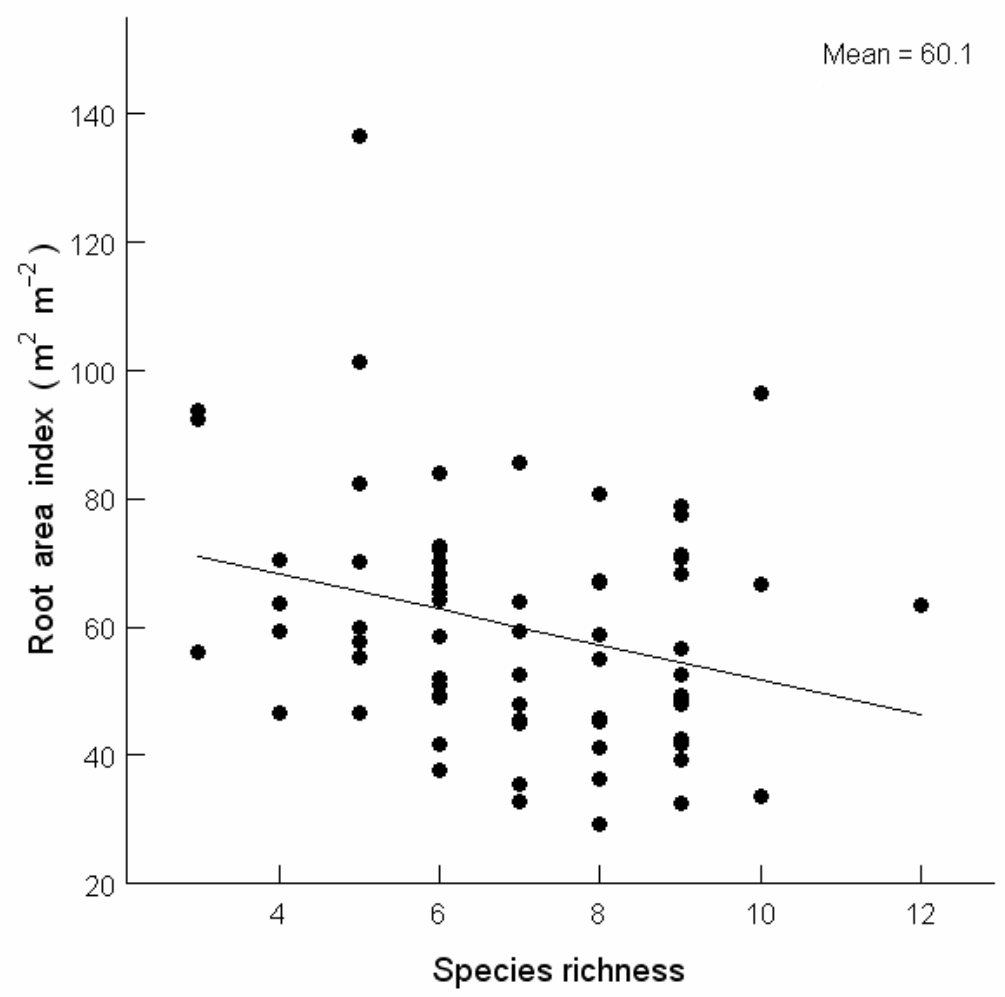

Figure 3.6: Dependence of root area index on species richness. $N=72$ plots. 


\subsection{Discussion}

\subsubsection{Effects of fertilization and mowing regime on productivity and biomass partitioning}

The most prominent result of our three-factorial manipulation study is that fertilization is the dominant factor determining aboveground productivity, while mowing frequency was of secondary importance. In our experiment, fertilization with a widely-used annual dose of NPK resulted in a ca. $30 \%$ increase in aboveground biomass accumulation (from about 1000 to $>1300 \mathrm{~g} \mathrm{~m}^{-2} \mathrm{yr}^{-1}$ ) compared to the unfertilized control. A further continuation of the fertilizer application most likely will shift the community further in the direction of more productive assemblages with eventual dominance of tall grasses such as Dactylis glomerata L., Festuca pratensis Huds. and Phleum pratense L. (Dierschke \& Briemle 2002).

NPK-fertilization typically leads to a reduction of the root:shoot biomass ratio of grassland plants (e.g., Speidel \& Weiß 1972, Poorter et al. 1995, Reynolds \& D' Antonio 1996, Schippers et al. 1999). This allocation shift is always based on a stimulation of shoot growth leading to a higher aboveground biomass, while root growth and belowground biomass often change only little. Concordantly, we found a decrease in R:S upon fertilization which resulted from the about $30 \%$ larger aboveground biomass, while root biomass did not decrease significantly.

In accordance with literature reports (e.g., Bernhardt-Römermann et al. 2011), increased mowing frequency led to a higher AGB. Since the root biomass was reduced by not more than $10 \%$ with the increase in mowing frequency, we assume the increase of AGB to be attributed mostly to a higher light availability and younger, more active leaves being present after a cutting event, but assume that carbohydrate allocation from roots to shoots plays only a secondary role. Compared to the fertilization effect was the influence of a higher cutting frequency of only secondary importance for AGB and its influence on root biomass was weak. 


\subsubsection{Negative diversity-productivity relationship and herbicide effects on} aboveground biomass

Species richness and functional diversity were manipulated synchronously by herbicide application at the GrassMan experimental site. A high abundance of grasses was coupled with a low number of species, while plots with high dicot abundance harboured a higher number of species. Although this relationship complicates the separation of effects caused by functional group abundance (i.e. resulting from herbicide treatment) and species richness per se, it represents a more realistic species loss scenario than is created in the more artificial settings of most biodiversity experiments with random species assemblages (Díaz et al. 2003, Bardgett \& Wardle 2010). In natural or semi-natural grasslands, the most productive communities are typically species-poor with dominance of a few N-demanding competitive grasses (e.g., Kahmen et al. 2002, Maurer et al. 2006, Hautier et al. 2009, Krause et al. 2011). Moreover, species losses induced by NPK-fertilization are often accompanied by an increase of the abundance of grasses at the expense of herb cover (Dierschke \& Briemle 2002, Gross et al. 2009).

The observed negative effect of species richness on aboveground biomass production is in agreement with the findings in the majority of studies analysing the diversity-productivity relationship in permanent grasslands (Silvertown 1980, Oomes 1992, Kenkel et al. 2000, Kahmen et al. 2005, Thompson et al. 2005, Grace et al. 2007). We hypothesize that the negative relation is mainly caused by the dominant effect of size-asymmetric competitive interactions between a few large tussock grasses and a matrix of smaller grasses or herbs in the Solling grassland, while complementary resource use most likely is of subordinate importance at this small neighbourhood scale. This hypothesis is supported by the observed negative effect of a reduction in monocot abundance on sward biomass, but a lacking biomass effect of a reduction in dicot abundance. The dominant role of a few grass species is reflected by the fact that herbicides sprayed against monocots increased the species richness by only one species per $0.25 \mathrm{~m}^{2}$, while the produced aboveground biomass decreased markedly (by $133 \mathrm{~g} \mathrm{~m}^{-2}$ ). In contrast, the experimental reduction of dicot abundance decreased species richness by two species per $0.25 \mathrm{~m}^{2}$, but had no effect on aboveground biomass. The negative effect of species richness on aboveground biomass was visible when the effect of the herbicide treatments was investigated separately and also when the different herbicide and management treatments were included in one model (data not shown). 
The independence of the species richness effect from the management regime is in accordance with results obtained in the Park Grass Experiment, where fertilization had no effect on the slope of the species richness-biomass relationship (Silvertown 1980). A contrasting result was recently reported by Bernhardt-Römermann et al. (2011) who found in a long-term experiment that the type of management can affect the relationship between diversity and productivity in grasslands: a negative relationship existed in meadows cut once in autumn, while the diversity-productivity relation was positive at higher cutting frequencies or with a cutting event early in spring. Although cutting frequency did not influence the relationship between diversity and aboveground biomass in our study, we found such an influence on the diversity-fine root biomass relation. In plots cut only once, where fine root biomass tended to be larger than in plots cut three times, root biomass decreased with species richness, an effect that we explain with size-asymmetric competition between a few large grasses and a matrix of smaller grasses and herbs, in a similar manner as in the aboveground compartment. We assume that such an effect of dominant grass species is less pronounced in the plots cut three times per year where fine root biomass was smaller. To completely explain this effect, more precise root studies including analyses of fine root production would be needed.

\subsubsection{Evidence for belowground niche complementarity?}

Increased productivity of more species-rich stands in sown artificial grasslands is often explained by complementary resource use of species differing in their ecological niches (Hector et al. 1999, Loreau et al. 2001, Roscher et al. 2005, Kahmen et al. 2006, Verón et al. 2011). Increased belowground resource use may be achieved by deeper root penetration or a higher root surface area per soil volume, which allows exploring a larger soil volume for water and nutrients or to deplete the available soil water and nutrient pools more intensively (Reich et al. 1998, Coomes \& Grubb 2000). We used the deep root ratio (DRR, root biomass at $15-30 \mathrm{~cm}$ relative to that in the $0-30 \mathrm{~cm}$ profile) as a measure for the vertical distribution of the root system in the grassland stands and hypothesized it to increase with species richness due to more deep-reaching roots. Our analysis revealed not a positive, but a (marginally significant) negative relation between species richness and DRR which is contradicting our third hypothesis assuming spatial complementarity. However, it is in accordance with results of Mommer et al. (2010), who found no diversity effect on the depth distribution of the root 
system in an experiment in synthetic grasslands. The lower DRR value in species-richer plots may perhaps be a consequence of the herbicide effect in the -Dic plots where grasses with deeper rooting than herbs were promoted.

The insignificant effect of diversity on vertical root biomass distribution does not exclude the possibility that more species-rich grassland stands use more water and/or nutrients because certain species are more efficient in the water absorption per unit root biomass or root area than the species on average, or because more species-rich assemblages can explore a broader range of $\mathrm{N}$ and $\mathrm{P}$ sources in the soil. However, specific root length and root area index were negatively related to species richness in our experiment. Since both are related to resource capture (Eissenstat 1992, Reich et al. 1998, Eissenstat et al. 2000), it is unlikely that water and nutrient uptake are higher in more species-rich grassland plots.

\subsubsection{Conclusions}

In our field study on the diversity-productivity relationship in a permanent temperate grassland, the treatments were chosen to simulate the transition in grassland management from extensive (no fertilization, 1 cut) to intensive management (high fertilization, three cuts) and the large diversity losses that happened in the course of management intensification in the last 50 years. Our results allow the conclusion that the dramatic diversity reduction in a large part of European grasslands has most likely been irrelevant for temperate grassland productivity because the fertilization effect is overwhelming, contradicting results of Weigelt et al. (2009). Further, belowground complementary resource use came out not to be a relevant force for biomass production, although it might be important in more resource-limited ecosystems (Flombaum \& Sala 2008).

\subsection{References}

Bardgett, R.D. \& Wardle, D.A. (2010) Aboveground- belowground linkages: Biotic interactions, ecosystem processes and global change. Oxford University Press, Oxford.

Bernhardt-Römermann, M., Römermann, C., Sperlich, S. \& Schmidt, W. (2011) Explaining grassland biomass - the contribution of climate, species and functional diversity depends on fertilization and mowing frequency. Journal of Applied Ecology 48, 1088-1097.

Chase, J.M. \& Leibold, M.A. (2002) Spatial scale dictates the productivity-biodiversity relationship. Nature 416, 427-430. 
Coomes, D.A. \& Grubb, P.J. (2000) Impacts of root competition in forests and woodlands: A theoretical framework and review of experiments. Ecological Monographs 70, 171-207.

Dierschke, H. \& Briemle, G. (2002) Kulturgrasland. Ulmer Verlag, Stuttgart.

Díaz, S., Symstad, A.J., Chapin, F.S., Wardle, D.A. \& Huenneke, L.F. (2003) Functional diversity revealed by removal experiments. Trends in Ecology \& Evolution 18, 140-146.

Eissenstat, D.M. (1992) Costs and benefits of constructing roots of small diameter. Journal of Plant Nutrition 15, 763-782.

Eissenstat, D.M., Wells, C.E., Yanai, R.D. \& Whitbeck, J.L. (2000) Building roots in a changing environment: implications for root longevity. New Phytologist 147, 33-42.

Ellenberg, H. \& Leuschner, Ch. (2010) Vegetation Mitteleuropas mit den Alpen. (6 ${ }^{\text {th }}$ ed.) Ulmer Verlag, Stuttgart.

Flombaum, P. \& Sala, O.E. (2008) Higher effect of plant species diversity on productivity in natural than artificial ecosystems. Proceedings of the National Academy of Sciences of the United States of America 105, 6087-6090.

From, T., Petersen, U., and Isselstein, J. (2011) Productivity and forage quality of a phytodiverse semi-natural grassland under various management regimes. Available from Nature Precedings http://dx.doi.org/10.1038/npre.2011.6622.1

Grace, J.B., Anderson, T.M., Smith, M.D., Seabloom, E., Andelman, S.J., Meche, G., Weiher, E., Allain, L.K., Jutila, H., Sankaran, M., Knops, J., Ritchie, M. \& Willig, M.R. (2007) Does species diversity limit productivity in natural grassland communities? Ecology Letters 10, 680-689.

Grime, J.P. (1973) Competitive exclusion in herbaceous vegetation. Nature 242, 344-347.

Grime, J.P. (1997) Biodiversity and ecosystem function: The debate deepens. Science 277, 1260-1261.

Gross, N., Bloor, J.M.G., Louault, F., Maire, V. \& Soussana, J.F. (2009) Effects of land-use change on productivity depend on small-scale plant species diversity. Basic and Applied Ecology 10, 687-696.

Hautier, Y., Niklaus, P.A. \& Hector, A. (2009) Competition for light causes plant biodiversity loss after eutrophication. Science 324, 636-638.

Hector, A., Schmid, B., Beierkuhnlein, C., Caldeira, M.C., Diemer, M., Dimitrakopoulos, P.G., Finn, J.A., Freitas, H., Giller, P.S., Good, J., Harris, R., Hogberg, P., Huss-Danell, K., Joshi, J., Jumpponen, A., Körner, C., Leadley, P.W., Loreau, M., Minns, A., Mulder, C.P.H., O'Donovan, G., Otway, S.J., Pereira, J.S., Prinz, A., Read, D.J., Scherer-Lorenzen, M., Schulze, E.D., Siamantziouras, A.S.D., Spehn, E.M., Terry, A.C., Troumbis, A.Y., Woodward, F.I., Yachi, S. \& Lawton, J.H. (1999) Plant diversity and productivity experiments in European grasslands. Science 286, 1123-1127.

Hector, A. (2001) Biodiversity and functioning of grassland ecosystems: multi-site comparison. The functional consequences of biodiversity: empirical progress and theoretical extensions (eds A.P. Kinzig, S.W. Pacala, \& D. Tilman), pp 71-95. Princeton University Press, Princeton.

Hector, A. \& Bagchi, R. (2007) Biodiversity and ecosystem multifunctionality. Nature 448, 188-190.

Hooper, D.U. \& Vitousek, P.M. (1997) The effects of plant composition and diversity on ecosystem processes. Science 277, 1302-1305. 
Hooper, D.U., Chapin, F.S., Ewel, J.J., Hector, A., Inchausti, P., Lavorel, S., Lawton, J.H., Lodge, D.M., Loreau, M., Naeem, S., Schmid, B., Setala, H., Symstad, A.J., Vandermeer, J. \& Wardle, D.A. (2005) Effects of biodiversity on ecosystem functioning: A consensus of current knowledge. Ecological Monographs 75, 3-35.

Huston, M.A., Aarssen, L.W., Austin, M.P., Cade, B.S., Fridley, J.D., Garnier, E., Grime, J.P., Hodgson, J., Lauenroth, W.K., Thompson, K., Vandermeer, J.H. \& Wardle, D.A. (2000) No consistent effect of plant diversity on productivity. Science $\mathbf{2 8 9}$.

Isbell, F., Calcagno, V., Hector, A., Connolly, J., Harpole, W.S., Reich, P.B., Scherer-Lorenzen, M., Schmid, B., Tilman, D., van Ruijven, J., Weigelt, A., Wilsey, B.J., Zavaleta, E.S. \& Loreau, M. (2011) High plant diversity is needed to maintain ecosystem services. Nature 477, 199203.

Isbell, F.I., Polley, H.W. \& Wilsey, B.J. (2009) Species interaction mechanisms maintain grassland plant species diversity. Ecology 90, 1821-1830.

Kahmen, A., Perner, J., Audorff, V., Weisser, W. \& Buchmann, N. (2005) Effects of plant diversity, community composition and environmental parameters on productivity in montane European grasslands. Oecologia 142, 606-615.

Kahmen, A., Renker, C., Unsicker, S.B. \& Buchmann, N. (2006) Niche complementarity for nitrogen: An explanation for the biodiversity and ecosystem functioning relationship? Ecology 87, 1244-1255.

Kahmen, S., Poschlod, P. \& Schreiber, K.F. (2002) Conservation management of calcareous grasslands. Changes in plant species composition and response of functional traits during 25 years. Biological Conservation 104, 319-328.

Kato, Y., Kamoshita, A., Yamagishi, J., Imoto, H. \& Abe, J. (2007) Growth of rice (Oryza sativa L.) cultivars under upland conditions with different levels of water supply. 3. Root system development, soil moisture change and plant water status. Plant Production Science 10, 3-13.

Kenkel, N.C., Peltzer, D.A., Baluta, D. \& Pirie, D. (2000) Increasing plant diversity does not influence productivity: empirical evidence and potential mechanisms. Community Ecology 1, 165-170.

Krahulec, F., Skálová, H., Herben, T., Hadincová, V., Wildová.R. \& Pecháčková, S. (2001) Vegetation changes following sheep grazing in abandoned mountain meadows. Applied Vegetation Science 4, 97-102.

Krause, B., Culmsee, H., Wesche, K., Bergmeier, E. \& Leuschner, C. (2011) Habitat loss of floodplain meadows in north Germany since the 1950s. Biodiversity and Conservation 20, 2347-2364.

Lauenroth, W.K., Wade, A.A., Williamson, M.A., Ross, B.E., Kumar, S. \& Cariveau, D.P. (2006) Uncertainty in calculations of net primary production for grasslands. Ecosystems 9, 843-851.

Loreau, M., Naeem, S., Inchausti, P., Bengtsson, J., Grime, J.P., Hector, A., Hooper, D.U., Huston, M.A., Raffaelli, D., Schmid, B., Tilman, D. \& Wardle, D.A. (2001) Biodiversity and ecosystem functioning: Current knowledge and future challenges. Science 294 , 804-808.

Loreau, M. \& Hector, A. (2001) Partitioning selection and complementarity in biodiversity experiments. Nature 412, 72-76.

Maurer, K., Weyand, A., Fischer, M. \& Stöcklin, J. (2006) Old cultural traditions, in addition to land use and topography, are shaping plant diversity of grasslands in the Alps. Biological Conservation 130, 438-446. 
Mommer, L., van Ruijven, J., de Caluwe, H., Smit-Tiekstra, A.E., Wagemaker, C.A.M., Ouborg, N.J., Bogemann, G.M., van der Weerden, G.M., Berendse, F. \& de Kroon, H. (2010) Unveiling below-ground species abundance in a biodiversity experiment: a test of vertical niche differentiation among grassland species. Journal of Ecology 98, 1117-1127.

Naeem, S., Thompson, L.J., Lawler, S.P., Lawton, J.H. \& Woodfin, R.M. (1994) Declining biodiversity can alter the performance of ecosystems. Nature 368, 734-737.

Oomes, M.J.M. (1992) Yield and species density of grasslands during restoration management. Journal of Vegetation Science 3, 271-274.

Petersen, U., Wrage, N., Köhler, L., Leuschner, C. \& Isselstein, J. (2011) Manipulating the species composition of permanent grasslands - A new approach to biodiversity experiments. Basic and Applied Ecology in press, doi:10.1016/j.baae.2011.10.003.

Pinheiro, J., Bates, D., DebRoy, S., Sarkar, D., and R Development Core Team. nlme: linear and nonlinear mixed effects models. 2011.

Poorter, H., Vandevijver, C.A.D.M., Boot, R.G.A. \& Lambers, H. (1995) Growth and carbon economy of a fast-growing and a slow-growing grass species as dependent on nitrate supply. Plant and Soil 171, 217-227.

R Development Core Team. R: A language and environment for statistical computing. 2011. Vienna, Austria.

Reich, P.B., Walters, M.B., Tjoelker, M.G., Vanderklein, D. \& Buschena, C. (1998) Photosynthesis and respiration rates depend on leaf and root morphology and nitrogen concentration in nine boreal tree species differing in relative growth rate. Functional Ecology 12, 395-405.

Reynolds, H.L. \& D' Antonio, C. (1996) The ecological significance of plasticity in root weight ratio in response to nitrogen: Opinion. Plant and Soil 185, 75-97.

Roscher, C., Temperton, V.M., Scherer-Lorenzen, M., Schmitz, M., Schumacher, J., Schmid, B., Buchmann, N., Weisser, W.W. \& Schulze, E.D. (2005) Overyielding in experimental grassland communities - irrespective of species pool or spatial scale. Ecology Letters 8, 419429.

Sala, O.E., Chapin, F.S., Armesto, J.J., Berlow, E., Bloomfield, J., Dirzo, R., Huber-Sanwald, E., Huenneke, L.F., Jackson, R.B., Kinzig, A., Leemans, R., Lodge, D.M., Mooney, H.A., Oesterheld, M., Poff, N.L., Sykes, M.T., Walker, B.H., Walker, M. \& Wall, D.H. (2000) Global biodiversity scenarios for the year 2100. Science 287, 1770-1774.

Schippers, P., Snoeijing, I. \& Kropff, M.J. (1999) Competition under high and low nutrient levels among three grassland species occupying different positions in a successional sequence. New Phytologist 143, 547-559.

Schmid, B., Joshi, J. \& Schläpfer, F. (2001) Empirical evidence for biodiversity- ecosystem functioning relationships. The functional consequences of biodiversity: empirical progress and theoretical extensions (eds A.P. Kinzig, S.W. Pacala, \& D. Tilman), pp 120-150. Princeton University Press, Princeton.

Silvertown, J. (1980) The dynamics of a grassland ecosystem - Botanical equilibrium in the Park Grass Experiment. Journal of Applied Ecology 17, 491-504.

Smith, M.D. \& Knapp, A.K. (2003) Dominant species maintain ecosystem function with non-random species loss. Ecology Letters 6, 509-517. 
Speidel, B. \& Weiss, A. (1972) Zur ober- und unterirdischen Stoffproduktion einer Goldhaferwiese bei verschiedener Düngung. Angewandte Botanik 46, 75-93.

Suding, K.N., Miller, A.E., Bechtold, H. \& Bowman, W.D. (2006) The consequence of species loss on ecosystem nitrogen cycling depends on community compensation. Oecologia 149, 141-149.

Tasser, E. \& Tappeiner, U. (2002) Impact of land use changes on mountain vegetation. Applied Vegetation Science 5, 173-184.

Thompson, K., Askew, A.P., Grime, J.P., Dunnett, N.P. \& Willis, A.J. (2005) Biodiversity, ecosystem function and plant traits in mature and immature plant communities. Functional Ecology 19, $355-358$

Tilman, D. (1993) Species richness of experimental productivity gradients - How important is colonization limitation? Ecology 74, 2179-2191.

Tilman, D. \& Downing, J.A. (1994) Biodiversity and stability in grasslands. Nature 367, 363-365.

Tilman, D., Wedin, D.A. \& Knops, J. (1996) Productivity and sustainability influenced by biodiversity in grassland ecosystems. Nature 379, 718-720.

Van Peer, L., Nijs, I., Reheul, D. \& De Cauwer, B. (2004) Species richness and susceptibility to heat and drought extremes in synthesized grassland ecosystems: compositional vs physiological effects. Functional Ecology 18, 769-778.

Verón, S.R., Paruelo, J.M. \& Oesterheld, M. (2011) Grazing-induced losses of biodiversity affect the transpiration of an arid ecosystem. Oecologia 165, 501-510.

Waesch, G. (2003) Montane Graslandvegetation des Thüringer Waldes. Cuvillier Verlag, Göttingen.

Weigelt, A., Weisser, W.W., Buchmann, N. \& Scherer-Lorenzen, M. (2009) Biodiversity for multifunctional grasslands: equal productivity in high-diversity low-input and low-diversity high-input systems. Biogeosciences 6, 1695-1706.

Yachi, S. \& Loreau, M. (2007) Does complementary resource use enhance ecosystem functioning? A model of light competition in plant communities. Ecology Letters 10, 54-62.

Zechmeister, H.G., Schmitzberger, I., Steurer, B., Peterseil, J. \& Wrbka, T. (2003) The influence of land-use practices and economics on plant species richness in meadows. Biological Conservation 114, 165-177.

Table 3A.1: Climatic conditions between April and September 2009 at the GrassMan site. Given are monthly sums (global radiation, precipitation) and means (temperature) measured with a climatic station at $2 \mathrm{~m}$ height.

\begin{tabular}{lcccccc}
\hline Month & April & May & June & July & August & Sept. \\
\hline Global radiation $\left(\mathrm{MJ} \mathrm{m}^{-2}\right)$ & 425 & 493 & 444 & 488 & 456 & 266 \\
Precipitation $(\mathrm{mm})$ & 22 & 70 & 53 & 113 & 49 & 81 \\
Temperature $\left({ }^{\circ} \mathrm{C}\right)$ & 12 & 12 & 13 & 17 & 18 & 14 \\
\hline
\end{tabular}





\section{CHAPTER 4}

Effects of fertilization and cutting frequency on the water balance of a temperate grassland

Laura Rose, Heinz Coners, Christoph Leuschner

Published in Ecohydrology 2011

(online first) DOI: 10.1002/eco.201 


\subsection{Abstract}

In large areas of Central Europe, grassland management has shifted from extensive grazing and mowing to highly intensive systems during the last 50 years. While effects on biodiversity have intensively been studied, little is known about the response of important ecosystem functions, in particular water and nutrient cycling, to management intensification.

We conducted a two-factorial grassland management experiment (GrassMan) with two cutting frequencies (one / three cuttings per year) and two fertilization levels (non-fertilized / $\mathrm{N}$-fertilized) in a moderately species-rich temperate grassland to analyse the effects of management regimes on evapotranspiration (ET) and infiltration (I). Both were measured in the growing season 2009 with small, weighable lysimeters that contained undisturbed soil monoliths and vegetation. Aboveground biomass production (ANPP), belowground biomass, root length density, plant diversity, water use efficiency (WUE), and climatic factors were also measured.

Fertilization with $180 \mathrm{~kg} \mathrm{~N} \mathrm{ha}^{-1} \mathrm{yr}^{-1}$ increased aboveground biomass production by $50-$ $70 \%$ and stand ET by $10-15 \%$ (or $20-40 \mathrm{~mm}$ ), while infiltration and ground water recharge decreased by about $50 \%$. Consequently, fertilization increased the WUE of the grassland plants by $20-30 \%$. However, increasing the mowing frequency from one to three had no significant effect. We found close relations between ANPP and ET and I and conclude that grassland management intensification influences the water balance primarily through fertilization effects on productivity. In areas of central Europe with abundant grassland, groundwater recharge must have significantly decreased with management intensification in the past 50 years. 


\subsection{Introduction}

In the last 50 years, land-use changes in temperate grassland ecosystems occurred either by land-use intensification, i.e. increased fertilization, cutting frequency and stocking rate, or by abandonment of non-profitable sites mostly on low productive soils (e.g., Vitousek et al. 1997, Sala et al. 2000, Krahulec et al. 2001, Tasser \& Tappeiner 2002). Such land-use changes can have profound effects on the structure of the vegetation, in particular the species composition, the amount of standing dead biomass, and on biogeochemical cycles (Greenwood et al. 1992, Rosset et al. 2001). Plant water consumption is an important ecosystem function regulating the partitioning of water to evapotranspiration, deep seepage and runoff. Grasslands are important source areas of groundwater recharge in many temperate regions because they typically transpire less than forests. Changes in grassland management may alter evapotranspiration and thus the amount of precipitation that drains to the subsoil.

In large areas of central Europe, grassland management has shifted from extensive grazing and mowing regimes to highly intensive pastures and meadows since the 1960 s or 1970s, proceeding from one to three - six cuttings per season and adding $150-300 \mathrm{~kg}$ nitrogen fertilizer $\mathrm{ha}^{-1}$ instead of no or minimal fertilization in the past. In the alluvial lowlands of northern Germany, more than $90 \%$ of the former extensively used mesic meadows have been converted to intensively used meadows and pastures or transformed to other agricultural land-use forms in the past 50 years (Wesche et al. 2009). This intensification results in a higher aboveground biomass and leaf area in the short periods before the cuttings, but also in an extension of the periods with low vegetation height after mowing. Moreover, the plant species composition changed progressively from grasses and herbs with moderate to low $\mathrm{N}$ demand to high $\mathrm{N}$-demanding grassland species with elevated assimilation and growth rates, but also higher transpiration rates. Thus, increasing fertilization and cutting frequencies alter vegetation structure and the physiological constitution of the dominant species synchronously which complicates predictions on the water consumption and deep seepage of different grassland management systems.

Evapotranspiration can be influenced by different land-use practices via changes in biomass and litter production, leaf area index, or species composition (Monteith 1988, Greenwood et al. 1992, Schulze et al. 1994, Rosset et al. 2001, Polley et al. 2008, Verheyen et al. 2008). Hence, land-use changes such as increased fertilizer application and higher cutting frequencies, or alternatively grassland extensification, have the potential to markedly 
alter the water balance of temperate meadows and pastures through effects on the water flux regulation by the plant and altered boundary layer climates (Klapp 1971, Husemann \& Wesche 1964). We are not aware of a study that investigated the isolated and combined effects of $\mathrm{N}$ fertilization and increased cutting frequency on the water balance of temperate meadow systems.

In this study, we used a two-factorial experimental design with six-fold replication at the plot level to investigate the effect of a large increase in $\mathrm{N}$ fertilizer amount (from 0 to $180 \mathrm{~kg} \mathrm{ha}^{-1}$ ), of an increase in cutting frequency (from one to three cuts per season), and of a combination of both on water fluxes (evapotranspiration (ET) and infiltration (I) to the subsoil) in a Central European montane grassland. We operated 24 small weighable lysimeters (one per plot) that contained swards of undisturbed grassland of $210 \mathrm{~cm}^{2}$ size to test the hypotheses that (i) increasing $\mathrm{N}$ fertilization leads to higher evapotranspiration and reduced infiltration rates due to a higher aboveground biomass, while (ii) higher cutting frequencies reduce ET and increase I due to smaller average biomass.

\subsection{Material and methods}

\subsubsection{Study site and experimental design}

The study took place within the framework of the 'GrassMan' project, an interdisciplinary investigation at the University of Göttingen on the role of plant diversity for ecosystem functions in differently used meadows. The meadow plots were located at a grassland site on the experimental farm Relliehausen of the university in the Solling

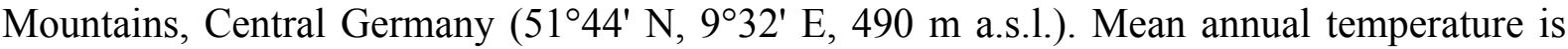
$6.9^{\circ} \mathrm{C}$ and annual precipitation is $1031 \mathrm{~mm}$ (monthly report of Deutscher Wetterdienst 1961 1990). The vegetation is a nutrient-poor, montane, mesic-moist to moist Lolio-Cynosuretum. In previous years, the site was used for extensive cattle grazing. The soils are haplic Cambisols with a $\mathrm{pH}_{\mathrm{H}_{2} \mathrm{O}}$ in the range of $5.2-5.6$. The whole experimental area ( $3 \mathrm{ha}$ ) was screened by soil coring prior to the start of the experiment to test for sufficient homogeneity of soil development and soil profile depth.

The full factorial block design of the study includes two NPK-fertilization (NPK-, $\mathrm{NPK}+)$ and two cutting treatments $(\mathrm{C} 1, \mathrm{C} 3)$ leading to four different treatments in total with 
six replications per treatment. The twenty-four plots $(15 \mathrm{~m} \times 15 \mathrm{~m})$ were arranged in six blocks of four plots each.

Table 4.1: Management procedures conducted at the experimental site before (2008) and during the experiment (2009). Treatments differ in fertilization (NPK+ / NPK-) and cutting frequency (C1 / C3).

\begin{tabular}{|c|c|c|c|c|c|c|c|c|}
\hline \multirow{3}{*}{ Treatment } & \multicolumn{3}{|l|}{2008} & \multicolumn{5}{|l|}{2009} \\
\hline & $01 / 07$ & $\begin{array}{l}26 / 08 \\
50\end{array}$ & 04/11 & $15 / 04$ & 14/05 & $\begin{array}{l}28 / 05 \\
90 \mathrm{~kg} \mathrm{Nha}^{-1}\end{array}$ & $\begin{array}{l}\text { 09/07 } \\
\text { Cutting }\end{array}$ & $\begin{array}{l}01 / 10 \\
\text { Cutting }\end{array}$ \\
\hline & Cutting & $50 \mathrm{~kg} \mathrm{~N} \mathrm{ha}^{-1}$ & & $90 \mathrm{~kg} \mathrm{~N} \mathrm{ha}^{-1}$ & & $90 \mathrm{~kg} \mathrm{~N} \mathrm{ha}^{-1}$ & & \\
\hline NPK-C1 & $\mathbf{x}$ & & & & & & $\mathbf{x}$ & \\
\hline $\mathrm{NPK}+\mathrm{C} 1$ & $\mathbf{x}$ & $\mathbf{x}$ & & $\mathbf{x}$ & & $\mathbf{x}$ & $\mathbf{x}$ & \\
\hline NPK-C3 & $\mathbf{x}$ & & $\mathbf{x}$ & & $\mathbf{x}$ & & $\mathbf{x}$ & $\mathbf{x}$ \\
\hline $\mathrm{NPK}+\mathrm{C} 3$ & $\mathbf{x}$ & $\mathbf{x}$ & $\mathbf{x}$ & $\mathbf{x}$ & $\mathbf{x}$ & $\mathbf{x}$ & $\mathbf{x}$ & $\mathbf{x}$ \\
\hline
\end{tabular}

To simulate different management intensities, half of the plots were cut once a year in July (C1: low management intensity) and half of them were cut three times a year (May, July, and September/November; C3: high management intensity). Half of the plots of each cutting treatment were $\mathrm{N}$-fertilized $\left(\mathrm{NPK}+, 180 \mathrm{~kg} \mathrm{~N} \mathrm{ha}^{-1} \mathrm{yr}^{-1}\right.$ applied as a mix of $\mathrm{NH}_{4} \mathrm{NO}_{3}$ and $\mathrm{CaCO}_{3}, 74: 26 \mathrm{w} / \mathrm{w}$ ) and half of them received no fertilizer (NPK-; Table 4.1). All NPK+ plots were additionally PK-fertilized on June 04,2009 with $30 \mathrm{~kg} \mathrm{P} \mathrm{ha}^{-1}$ and $107 \mathrm{~kg} \mathrm{~K} \mathrm{ha}^{-1}$ to compensate for nutrient export during the former cattle grazing regime.

\subsubsection{Measurement of evapotranspiration, infiltration, leaf-level WUE and}

\section{local climate in the grassland plots}

To measure evapotranspiration and infiltration rates, 24 weighable lysimeters (one lysimeter per plot) were installed in October 2008. The lysimeters consisted of a steel tube (diameter $16.5 \mathrm{~cm}$, length $30 \mathrm{~cm}$ ) which contained an undisturbed soil monolith of the upper $30 \mathrm{~cm}$ and the undisturbed grassland sward of $210 \mathrm{~cm}^{2}$ size on top of it. The soil depth of $30 \mathrm{~cm}$ represents the maximum rooting depth for the large majority of grassland plants at this site and also marks the soil depth where gravel content starts to increase. To extract the monoliths, the tubes were carefully installed on the soil surface without damaging the vegetation and then slowly pushed downwards by applying hydraulic pressure while excavating a thin layer of soil on the outer tube surface to monitor the lower edge of the tube. After extracting the steel tube with the intact soil monolith, the bottom of the tube was sealed with a ceramic filter plate and connected to a glass bottle to collect the drainage water by suction. To simulate the gravitation force on the drainage water and to avoid water-logging in the tube, $-50 \mathrm{hPa}$ suction was applied to the bottle. The lysimeters and bottles were left in the 
soil inside of plastic tubes of slightly larger diameter and were only removed for weighing. Since the extraction of the monolith inevitably resulted in a certain, though minor disturbance of the surrounding grassland vegetation, new shafts were excavated at a distance of $20 \mathrm{~cm}$ to house the lysimeter tube and monolith within a patch of undisturbed meadow vegetation of similar height and composition. The bottles were installed by using the initially established lysimeter access shafts. Any damage to the surrounding grassland vegetation resulting from the installation works had virtually disappeared at the beginning of the vegetation period 2009.

We conducted continuous measurements of precipitation (Tipping Bucket Rain Gauge 52202; RM Young Company, Traverse City, USA), global radiation (CS300 Pyranometer, Campbell Sci., Shepshed, UK), relative air humidity and air temperature (CS215, Campbell) on the site. Ten-minute means or totals (precipitation) were recorded by a CR800 datalogger (Campbell). The vapor pressure deficit (VPD) was calculated from data of relative air humidity and air temperature using the Magnus equation (Buck 1981).

Measurements started on April 07, 2009 and were continued until September 09, 2009 covering the main growing season. In the six-months measuring period, the cutting event of the $\mathrm{C} 1$ treatment and two of the three cutting events in the $\mathrm{C} 3$ treatment were covered before the lysimeters were harvested destructively in September 2009.

The soil monoliths and bottles were weighed every other week with a mobile electronic balance to a resolution of $0.1 \mathrm{~g}$. The infiltration rate into the subsoil was calculated from the increase in bottle weight over time. The evapotranspiration rate (ET) of the swards was obtained from the differences in lysimeter weight, soil infiltration rate and the precipitation for the given time period. Because ET was measured through the weight loss of the monoliths, any increase in biomass on top of the monolith would have led to an underestimation of evapotranspiration. Consequently, the lysimeter weight was corrected for biomass accumulation before calculating ET. The mean daily increase in fresh plant biomass for the time periods between the cuttings was calculated from the fresh weight of biomass that was harvested on a $22.5 \mathrm{~m}^{2}$ area in every $15 \times 15 \mathrm{~m}$ plot synchronously to the cutting procedures of the lysimeter swards (Table 4.1). It was not possible to quantify changes in belowground biomass. However, this shortcoming should not have seriously affected the hydrological comparison of the treatments because the belowground biomass did not differ between the management regimes in our experiment. Water use efficiency (WUE) was calculated as the quotient of aboveground dry mass production (see below) and water loss through ET. Precipitation interception (IN) by the meadow vegetation was ignored here 
because earlier measurements in a nearby montane meadow had shown that $\mathrm{IN}$ is in fact of minor importance as a loss term in the water balance. When evaporation of intercepted water from the dense grass canopy occurs, transpiration is effectively suppressed due to air humidities close to saturation (Leuschner 1987). Thus, measured ET represents mostly water lost through transpiration, while the evaporation of intercepted water and soil evaporation both can be ignored in a first approximation.

The water use efficiency of photosynthesis ( $\mathrm{mg} \mathrm{CO}_{2}$ assimilated per $\mathrm{g} \mathrm{H}_{2} \mathrm{O}$ transpired) was measured in five of the most abundant species (Agrostis capillaris L., Dactylis glomerata L., Festuca rubra L., Rumex acetosa L., Trifolium repens L.) in the 24 plots between June 27 and June 29, 2009 using a Li-6400 portable photosynthesis system (LI-COR Biosciences, Lincoln, Nebraska, USA). Measurements were made at light saturation $\left(2000 \mu \mathrm{mol} \mathrm{m} \mathrm{m}^{-2}\right)$ and $25^{\circ} \mathrm{C}$ leaf temperature; relative humidity was kept at $40 \%$ in the sample chamber.

\subsubsection{Vegetation data and biomass sampling}

At the end of the measurement period on September 09, the aboveground biomass of each lysimeter was harvested by clipping at the soil surface and sorted by plant species; species richness was also calculated from these data. The leaf litter was collected separately. Aboveground biomass production was estimated as the sum of hay biomass removed during the first and second cutting events plus the standing aboveground biomass present at the last harvest before the third cutting.

The belowground biomass was determined by extracting four soil samples per lysimeter with a soil corer of $3.5 \mathrm{~cm}$ in diameter. The roots were cleaned from soil residues using a sieve (mesh size $0.2 \mathrm{~mm}$ ) and subsequently sorted by diameter (fine roots $\leq 2 \mathrm{~mm}$, coarse roots $>2 \mathrm{~mm}$ ). The separation of living and dead roots was not possible. One representative subsample per root sample was digitalized on a flatbed-scanner using the software WinRhizo 2005c (Régent Instr., Québec, Canada) to calculate root length density (RLD, $\mathrm{m} \mathrm{m}^{-3}$ ). All plant material was dried $\left(70{ }^{\circ} \mathrm{C}, 80 \mathrm{~h}\right)$ and weighed to $1 \mathrm{mg}$.

\subsubsection{Weather conditions during the measurement period}

The mean air temperature in the 155 -d-long measurement period was $14.4^{\circ} \mathrm{C}$, (daily means $\left.6.3{ }^{\circ} \mathrm{C}-23.4{ }^{\circ} \mathrm{C}\right)$. The minimum temperature was reached on April $18\left(3.4{ }^{\circ} \mathrm{C}\right)$, and the 
maximum temperature on August $20\left(32.1^{\circ} \mathrm{C}\right)$. Precipitation in the measurement period was $292 \mathrm{~mm}$ (daily maximum $24 \mathrm{~mm}$ ). The global radiation total in the measurement period was $2300 \mathrm{MJ} \mathrm{m}^{-2}$ with a daily mean of $15 \mathrm{MJ} \mathrm{m}^{-2} \mathrm{~d}^{-1}$ (range $3-26 \mathrm{MJ} \mathrm{m}^{-2} \mathrm{~d}^{-1}$ ). The mean VPD during the measurement period was $0.54 \mathrm{kPa}$ (highest daily mean: $1.30 \mathrm{kPa}$ ). The volumetric soil water content in the upper $10 \mathrm{~cm}$ of the soil ranged between 28 and $36 \mathrm{vol} \%$ and there was no distinct dry period during our measurements (Figure 4.1B). The volumetric soil water content was calculated from the difference between wet and dry weight $\left(105^{\circ} \mathrm{C}, 24 \mathrm{~h}\right)$ of soil cylinders of a defined volume $\left(250 \mathrm{~cm}^{3}\right)$.

\subsubsection{Statistical analyses}

Statistical analyses were performed with the software SAS version 8.02 (SAS Institute, Cary, NC, USA) using a significance level of $P \leq 0.05$ throughout. All data were tested for normal distribution (Shapiro-Wilk test). Data of cumulative infiltration into the soil were arcsin-transformed to achieve normal distribution.

To identify the most important climatic factors controlling the hydraulic processes, Spearman's rank correlation analyses were performed for treatment means of ET and infiltration rate with a number of climatic factors. We performed a multiple regression analysis with VPD and global radiation as source variables and ET as response variable. to investigate whether both factors influenced ET independently and not due to a correlation between these two factors. The regression analysis proved the significant influence of both VPD and radiation on ET.

Two-way analyses of variance with the source variables fertilization, cutting frequency, and their interaction were performed by the ANOVA procedure for cumulative ET, cumulative infiltration, WUE (stand and leaf level), species richness and several biomass variables. Because there was no significant influence of the fertilization $\mathrm{x}$ cutting frequency interaction on any of these variables, we deleted this term from all models. Differences between two treatments were analyzed with a posthoc Tukey test.

In a multiple regression analysis, we analyzed the effect of aboveground biomass production, root length density, fine root biomass and species richness on cumulative ET and cumulative infiltration. The least significant variable was deleted stepwise until all included variables were significant at least on a level of $P \leq 0.1$. Subsequent to the regression analyses, 
Pearson single factor correlation analyses were performed for the variables significantly related to ET or infiltration.

\subsection{Results}

\subsubsection{Evapotranspiration and infiltration as controlled by climatic factors}

The grass swards in the lysimeters transpired in the measurement period April to September 2009 at rates between 0.9 and $3.7 \mathrm{~mm} \mathrm{~d}^{-1}$. Highest ET rates were recorded in the period July 27 - August 07, when VPD and global radiation peaked; low ET rates occurred in the cool and moist periods in early May and mid July (Figure 4.1A). Daily mean ET rates in the measuring period were $1.8 \mathrm{~mm} \mathrm{~d}^{-1}$ (NPK-C1), $2.1 \mathrm{~mm} \mathrm{~d}^{-1}(\mathrm{NPK}+\mathrm{C} 1) 1.9 \mathrm{~mm} \mathrm{~d}^{-1}$ (NPK$\mathrm{C} 3)$ and $2.0 \mathrm{~mm} \mathrm{~d}^{-1}(\mathrm{NPK}+\mathrm{C} 3)$.

In all four treatments, the strongest climatic control on ET was exerted by VPD, followed by a significant positive effect of global radiation (Table 4.2). The independent effect of global radiation was confirmed by multiple regression analysis. Mean daily precipitation in a measuring interval did not have a significant influence on ET in the respective period in any of the treatments (Table 4.2).

The daily infiltration rates into the subsoil ranged between 0 and $0.6 \mathrm{~mm} \mathrm{~d}^{-1}$. Highest values were recorded between July 09 and July 27 when ET was low and rainfall high; lowest rates occurred in a dry period between June 23 and July 09 (Figure 4.1C). The daily infiltration rate was not significantly correlated with any of the measured climatic factors, although it tended to increase with the amount of daily precipitation (Figure 4.1D).

Table 4.2: Results of Spearman's rank correlation analyses of mean evapotranspiration and infiltration rates with different climatic parameters for the four different management treatments in the measurement period. + , $++=$ positive correlation $(P<0.05,0.01$ respectively $), 0=$ no correlation VPD: Vapor pressure deficit.

\begin{tabular}{|c|c|c|c|c|c|c|c|c|}
\hline & \multicolumn{4}{|c|}{ Evapotranspiration } & \multicolumn{4}{|c|}{ Infiltration } \\
\hline & NPK-C1 & $\mathrm{NPK}+\mathrm{C} 1$ & NPK-C3 & $\mathrm{NPK}+\mathrm{C} 3$ & NPK-C1 & $\mathrm{NPK}+\mathrm{C} 1$ & NPK-C3 & $\mathrm{NPK}+\mathrm{C} 3$ \\
\hline Global radiation & + & + & + & + & 0 & 0 & 0 & 0 \\
\hline Precipitation & 0 & 0 & 0 & 0 & 0 & 0 & 0 & 0 \\
\hline VPD & ++ & ++ & ++ & ++ & 0 & 0 & 0 & 0 \\
\hline
\end{tabular}


(

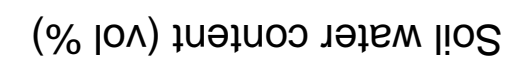

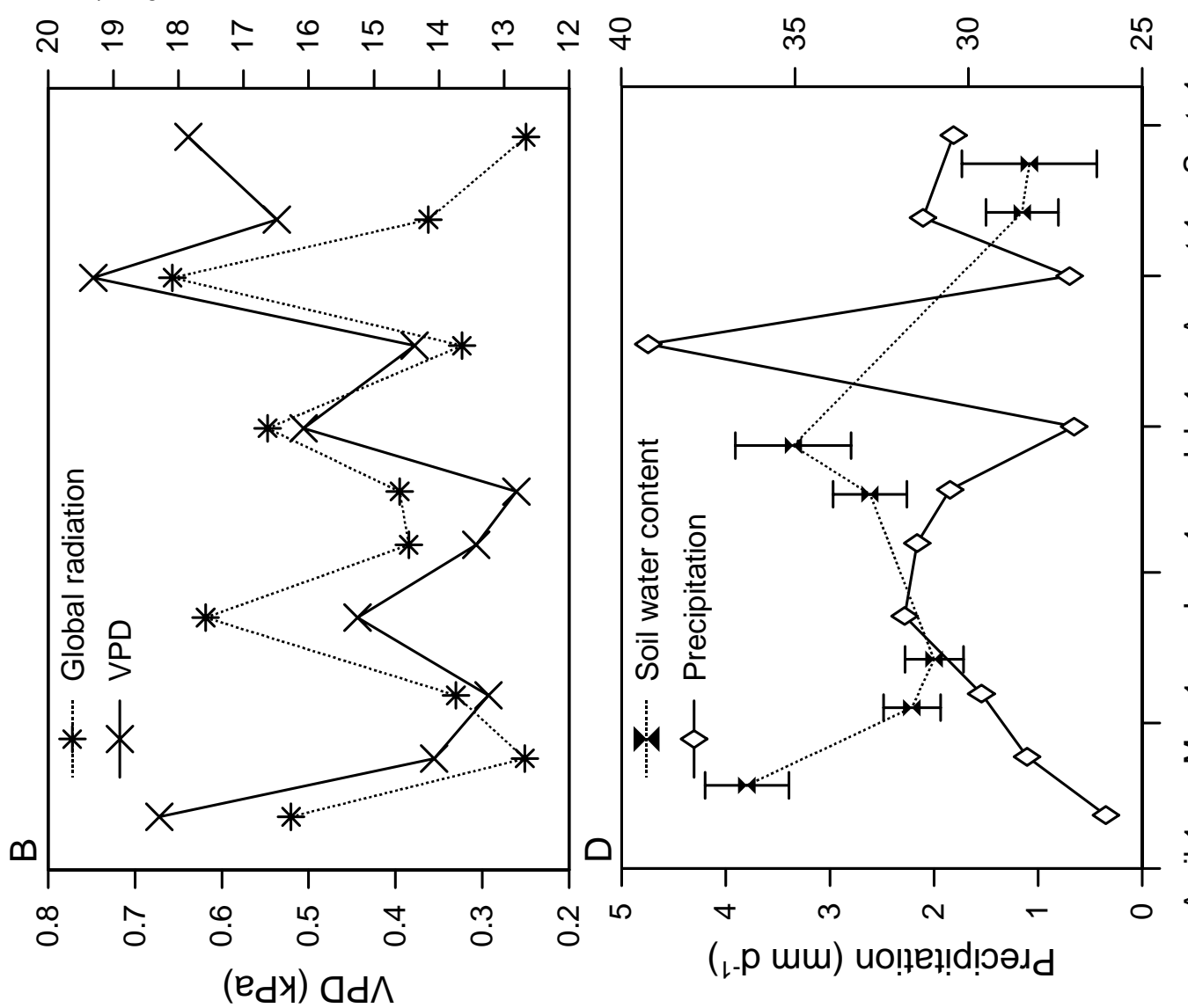

苞专

$-1-\overline{\mathrm{s}}$

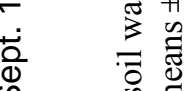

.

苞 $\quad$ 吾

인

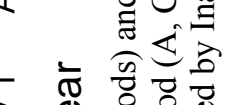

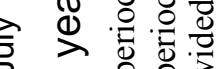

प

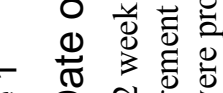

$\propto$ ๑

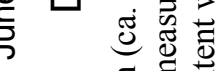

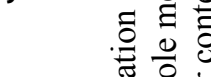

ㄱ.

$\sum \quad$ 更

- ब

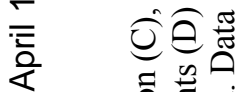

要

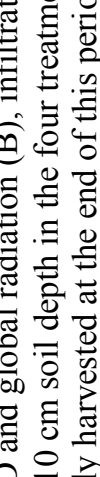

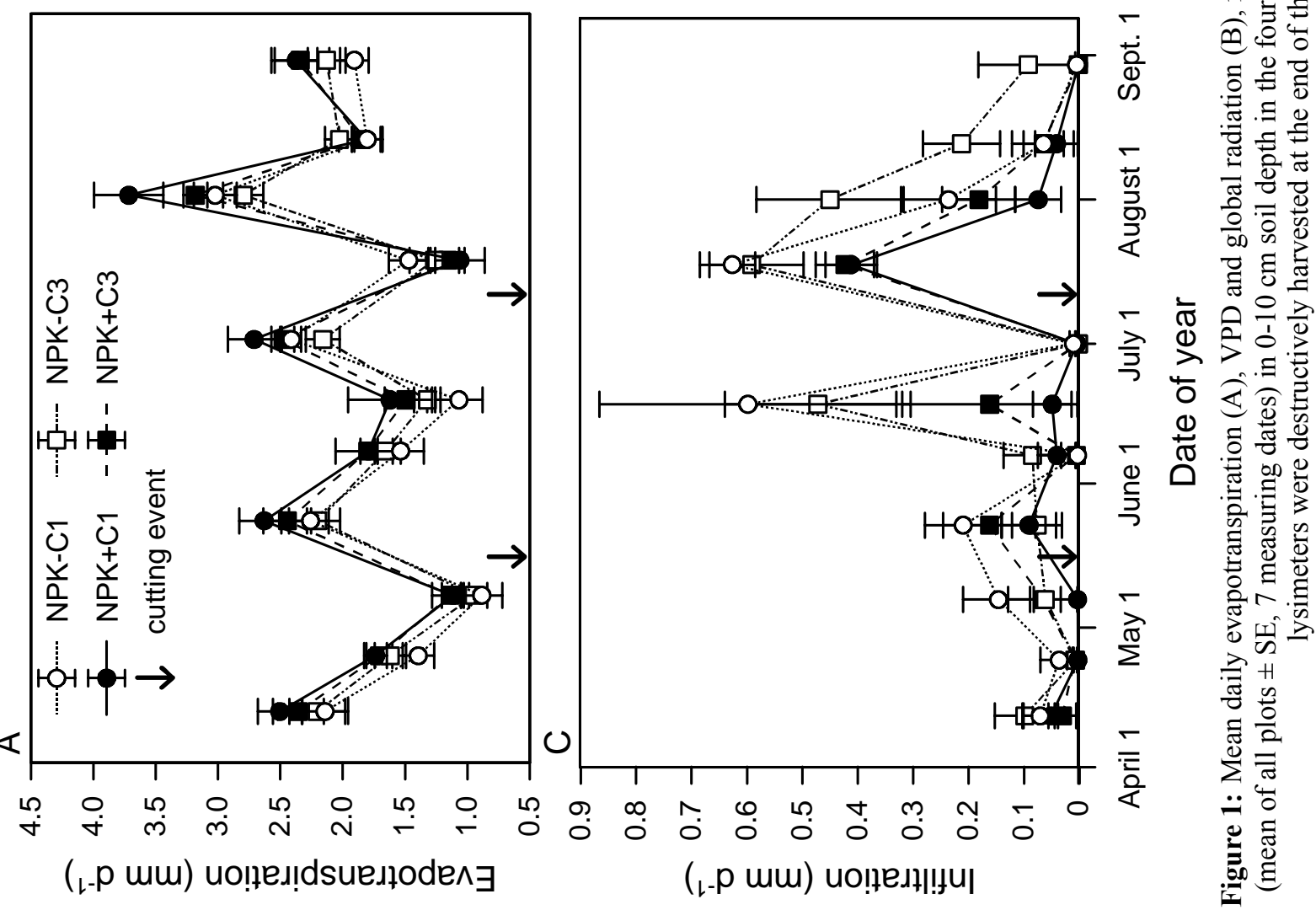




\subsubsection{The influence of different management regimes on water fluxes and plant}

\section{water use efficiency}

The cumulative ET in the period from April 07 to September 09 ranged between 282 and $324 \mathrm{~mm}$ in the four treatments (Figure 4.2A). It was significantly influenced by the fertilization regime, but not by cutting frequency (Table 4.3). Unfertilized swards with only one cutting (NPK-C1) had significantly lower $\mathrm{ET}_{\text {cum }}$ values than fertilized plots; a similar fertilization effect was observed in the intensively used $\mathrm{C} 3$ plots. However, $\mathrm{ET}_{\text {cum }}$ did not differ between swards with one (C1) and three (C3) cuttings.
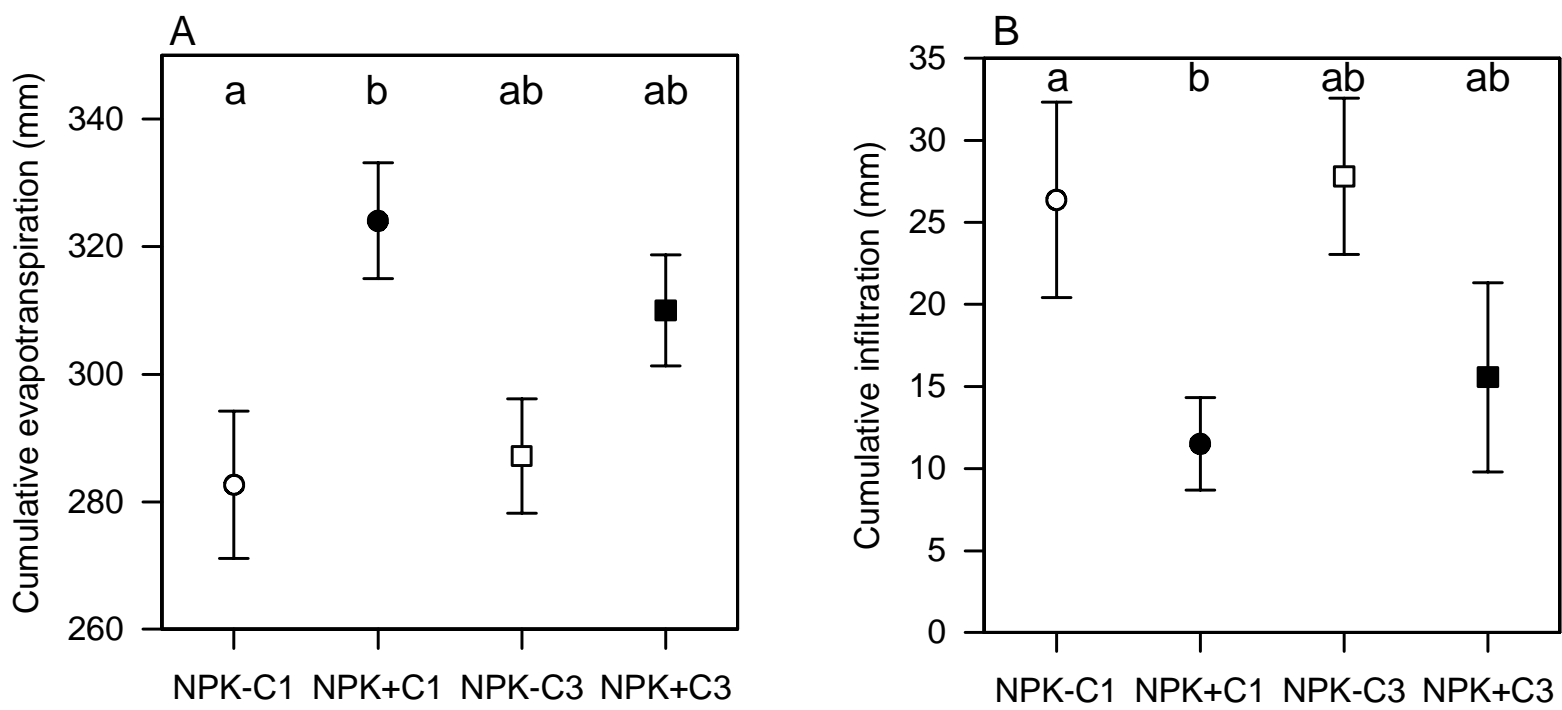

Figure 4.2: Cumulative values of evapotranspiration $(\mathrm{A})$ and infiltration $(\mathrm{B})$ in the four treatments over the whole observation period $(155 \mathrm{~d})$ (means $\pm \mathrm{SE})$. Different letters denote significant differences between treatments (Tukey test, $P<0.05, \mathrm{n}=5-6$ ).

From April 07 to September 09, between 12 and $28 \mathrm{~mm}$ water infiltrated into the subsoil (Figure 4.2B). Cumulative infiltration was significantly influenced by the fertilization regime, but not by cutting frequency (Table 4.3). Unfertilized plots with only one cutting (NPK-C1) had significantly higher infiltration rates than fertilized plots; the same (but statistically not significant) pattern was observed in the $\mathrm{C} 3$ plots. As for $\mathrm{ET}_{\text {cum }}, \mathrm{C} 1$ and $\mathrm{C} 3$ plots did not differ with respect to cumulative infiltration. After the second cutting in July, we observed a more rapid increase in infiltration rates in the unfertilized plots as compared to the fertilized ones (Figure 4.1C). 

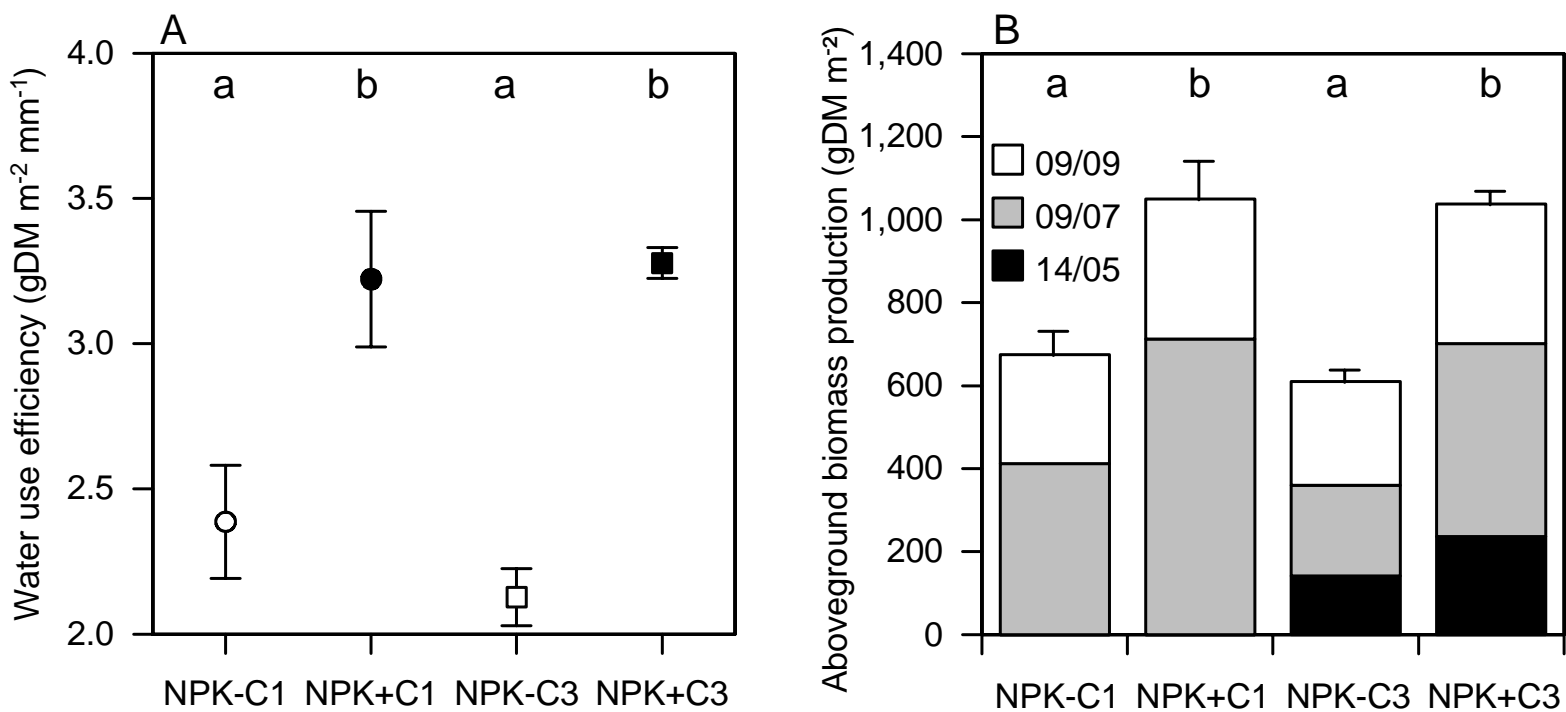

Figure 4.3: Water use efficiency (A; $\mathrm{g}$ DM produced per $\mathrm{mm}$ of water evaporated) and aboveground biomass production (B; different cutting dates and final harvest indicated by different colors) in the four treatments during the whole measurement period (means $\pm \mathrm{SE}$ ). Different letters indicate significant differences between treatments (Tukey test, $P<0.05, \mathrm{n}=5-6$ ).

The water use efficiency of the lysimeter swards ranged between 2.1 and $3.3 \mathrm{~g} \mathrm{DM}$ produced $\mathrm{m}^{-2}$ per mm water transpired (Figure 4.3A) and was significantly influenced by the fertilization regime, but not by cutting frequency (Table 4.3). WUE was significantly higher in the fertilized swards $\left(3.2-3.3 \mathrm{~g} \mathrm{DM} \mathrm{m}^{-2} \mathrm{~mm}^{-1}\right)$ than in the unfertilized plots $(2.1$ $2.4 \mathrm{~g} \mathrm{DM} \mathrm{m}^{-2} \mathrm{~mm}^{-1}$ ). Again, swards cut once a year did not differ in their WUE from swards with three cuts.

Table 4.3: ANOVA results on the influence of fertilization and cutting frequency on various hydrological and vegetation parameters (SS \% = percentage of sum of squares; WUE = water use efficiency).

\begin{tabular}{|c|c|c|c|c|c|c|c|c|c|}
\hline \multirow[t]{2}{*}{ Source } & \multicolumn{3}{|c|}{ Fertilization } & \multicolumn{3}{|c|}{ Cutting frequency } & \multicolumn{3}{|l|}{ Model } \\
\hline & $\mathrm{SS} \%$ & $F$ & $P$ & $\mathrm{SS} \%$ & $F$ & $P$ & $\mathrm{SS} \%$ & $F$ & $P$ \\
\hline Cumulative evapotranspiration & 35.78 & 11.31 & $<0.01$ & 0.95 & 0.3 & 0.59 & 36.73 & 5.81 & $<0.05$ \\
\hline Cumulative infiltration (arcsin) & 47.31 & 17.06 & $<0.001$ & 0.01 & 0 & 0.95 & 47.32 & 8.53 & $<0.01$ \\
\hline WUE & 65.24 & 36.37 & $<0.001$ & 0.67 & 0.38 & 0.55 & 65.91 & 18.37 & $<0.001$ \\
\hline Aboveground production & 70.06 & 47.74 & $<0.001$ & 0.59 & 0.4 & 0.53 & 70.65 & 24.07 & $<0.001$ \\
\hline Fine root biomass & 5.48 & 1.16 & 0.30 & 4.8 & 1.02 & 0.33 & 10.29 & 1.09 & 0.36 \\
\hline Root length density & 17.34 & 4.16 & 0.06 & 3.49 & 0.84 & 0.37 & 20.83 & 2.5 & 0.11 \\
\hline Root:shoot ratio & 1.46 & 0.29 & 0.60 & 1.93 & 0.38 & 0.55 & 3.38 & 0.33 & 0.72 \\
\hline Species richness & 16.17 & 4.01 & 0.06 & 3.27 & 0.81 & 0.38 & 19.44 & 2.41 & 0.12 \\
\hline
\end{tabular}

At the leaf level, the photosynthetic water use efficiency of 4 of the 5 measured species and the mean for all species was increased by fertilization and not affected by cutting frequency. Dactylis glomerata showed increased WUEs as a response to fertilization only in the $\mathrm{C} 3$ treatments. Means for all species ranged between 5.49 and $7.54 \mathrm{mg} \mathrm{CO}_{2}$ assimilated 
$\mathrm{g}^{-1} \mathrm{H}_{2} \mathrm{O}$ transpired and were increased 22 to $25 \%$ by fertilization $(\mathrm{C} 1$ and $\mathrm{C} 3$, respectively, Table 4.4).

Table 4.4: Water use efficiency $\left(\mathrm{mgCO}_{2}\right.$ assimilated per $\mathrm{gH}_{2} \mathrm{O}$ transpired) of five of the most abundant species and mean of all five species in the 24 plots between June 27 and June 29 (means \pm SE). Different letters denote significant differences between treatments (Tukey test, $P<0.05, \mathrm{n}=6$ ).

\begin{tabular}{|c|c|c|c|c|c|c|c|c|c|c|c|c|c|c|c|c|}
\hline \multirow{2}{*}{$\begin{array}{l}\text { Treatment } \\
\text { Species }\end{array}$} & \multicolumn{4}{|c|}{ NPK-C1 } & \multicolumn{4}{|c|}{$\mathrm{NPK}+\mathrm{C} 1$} & \multicolumn{4}{|c|}{ NPK-C3 } & \multicolumn{4}{|c|}{$\mathrm{NPK}+\mathrm{C} 3$} \\
\hline & Mean & \pm & SE & & Mean & \pm & SE & & Mean & \pm & SE & & Mean & \pm & SE & \\
\hline A. capillaris & 6.46 & \pm & 0.60 & $\mathrm{a}$ & 8.27 & \pm & 0.38 & $\mathrm{a}$ & 6 & \pm & 0.56 & $\mathrm{a}$ & 7.14 & \pm & 0.72 & $\mathrm{a}$ \\
\hline D. glomerata & 6.72 & \pm & 0.95 & $\mathrm{a}$ & 6.32 & \pm & 0.27 & $\mathrm{a}$ & 5.88 & \pm & 0.58 & $\mathrm{a}$ & 7.16 & \pm & 0.45 & $\mathrm{a}$ \\
\hline F. rubra & 5.14 & \pm & 0.66 & $\mathrm{a}$ & 8.07 & \pm & 0.86 & $\mathrm{~b}$ & 4.73 & \pm & 0.72 & $\mathrm{a}$ & 7.31 & \pm & 0.68 & $a b$ \\
\hline R. acetosa & 6.72 & \pm & 0.90 & $\mathrm{a}$ & 7.27 & \pm & 0.83 & $\mathrm{a}$ & 5.46 & \pm & 0.76 & $\mathrm{a}$ & 7.06 & \pm & 0.38 & $\mathrm{a}$ \\
\hline T. repens & 5.59 & \pm & 1.32 & $\mathrm{a}$ & 7.79 & \pm & 0.67 & $\mathrm{a}$ & 5.37 & \pm & 0.88 & $\mathrm{a}$ & 5.92 & \pm & 1.09 & $\mathrm{a}$ \\
\hline All species & 6.13 & \pm & 0.37 & $a b$ & 7.54 & \pm & 0.30 & $\mathrm{c}$ & 5.49 & \pm & 0.31 & $\mathrm{a}$ & 6.92 & \pm & 0.31 & bc \\
\hline
\end{tabular}

\subsubsection{Stand characteristics influencing cumulative evapotranspiration and} infiltration

The production of aboveground biomass in the growing season 2009 ranged between 609.9 (NPK-C3) and $1050.0 \mathrm{~g} \mathrm{~m}^{-2}(\mathrm{NPK}+\mathrm{C} 1$, Figure 4.3B). Aboveground production was significantly influenced by the fertilization regime, but not by the cutting frequency (Table 4.3). Fertilized plots had significantly higher production rates than unfertilized ones under both cutting treatments, whereas plots with three cuttings had a very similar production as the less intensively used $\mathrm{C} 1$ plots.

Neither fine root biomass nor root length density (RLD) were affected by the fertilization regime and/or cutting frequency (Table 4.3). We measured a standing fine root biomass in the four treatments between $169(\mathrm{NPK}+\mathrm{C} 3)$ and $249 \mathrm{~g} \mathrm{DM} \mathrm{m}^{-2}$ (NPK-C3; Table 4.5). The extensively used NPK-C1 plots had the lowest and the NPK $+\mathrm{C} 1$ plots the highest RLD values (449 and $687 \mathrm{~m} \mathrm{~m}^{-3}$, respectively; Table 4.5). The root:shoot ratio at the time of the last harvest (September 2009) ranged between 1.5 and $2.4 \mathrm{~g} \mathrm{~g}^{-1}$ (Table 4.5). It was neither affected by the fertilization regime nor by cutting frequency (Table 4.3) and no significant differences occurred between the four treatments, although the intensively used NPK $+\mathrm{C} 3$ treatment tended to have a higher root:shoot ratio than the other three treatments.

Despite the contrasts in fertilization and cutting intensity, the four treatments did not differ significantly in their plant species richness in the swards. However, the unfertilized plots tended to hold a higher phytodiversity than the fertilized plots (difference not 
significant). Mean species richness ranged between $5.5(\mathrm{NPK}+\mathrm{C} 1)$ and $7.7(\mathrm{NPK}-\mathrm{C} 3)$ species per lysimeter $\left(213 \mathrm{~cm}^{2}\right.$; Table 4.5$)$ and was significantly affected neither by fertilization nor cutting frequency (Table 4.3).

Table 4.5: Biomass characteristics and plant species richness (species per lysimeter) of the lysimeters in the four different treatments on 09.09.2009 (means \pm SE). Different letters denote significant differences between treatments (Tukey test, $P<0.05, \mathrm{n}=5-6)$.

\begin{tabular}{|c|c|c|c|c|c|c|c|c|c|c|c|c|c|c|c|c|}
\hline \multirow[t]{2}{*}{ Treatment } & \multicolumn{4}{|c|}{ NPK-C1 } & \multicolumn{4}{|c|}{$\mathrm{NPK}+\mathrm{C} 1$} & \multicolumn{4}{|c|}{ NPK-C3 } & \multicolumn{4}{|c|}{$\mathrm{NPK}+\mathrm{C} 3$} \\
\hline & Mean & \pm & SE & & Mean & \pm & SE & & Mean & \pm & SE & & Mean & \pm & $\mathrm{SE}$ & \\
\hline $\begin{array}{l}\text { Fine root biomass } \\
\left(\mathrm{g} \mathrm{m}^{-2}\right)\end{array}$ & 170.2 & \pm & 38.6 & $\mathrm{a}$ & 248.9 & \pm & 43 & $\mathrm{a}$ & 180.3 & \pm & 27.4 & $\mathrm{a}$ & 169.2 & \pm & 13.5 & $\mathrm{a}$ \\
\hline $\begin{array}{l}\text { Root length density } \\
\left(\mathrm{m} \mathrm{m}^{-3}\right)\end{array}$ & 449.1 & \pm & 82.48 & $\mathrm{a}$ & 687.24 & \pm & 79.71 & $\mathrm{a}$ & 462.23 & \pm & 83.46 & $\mathrm{a}$ & 530.27 & \pm & 56.94 & $\mathrm{a}$ \\
\hline $\begin{array}{l}\text { Root/shoot ratio } \\
\left(\mathrm{g} \mathrm{g}^{-1}\right)\end{array}$ & 2.299 & \pm & 0.482 & $\mathrm{a}$ & 2.111 & \pm & 0.232 & $\mathrm{a}$ & 2.396 & \pm & 0.362 & $\mathrm{a}$ & 1.544 & \pm & 0.082 & $\mathrm{a}$ \\
\hline Species richness & 6.6 & \pm & 0.7 & $\mathrm{a}$ & 5.5 & \pm & 0.9 & $\mathrm{a}$ & 7.7 & \pm & 0.7 & $a$ & 5.8 & \pm & 0.7 & $\mathrm{a}$ \\
\hline
\end{tabular}

Multiple regression models with stepwise variable elimination showed that the only factor influencing $\mathrm{ET}_{\text {cum }}$ or $\mathrm{I}_{\text {cum }}$ (arcsin-transformed) was aboveground biomass production. According to Pearson single factor regression analyses, the biomass production - $\mathrm{ET}_{\text {cum }}$ relationship and the negative relationship between aboveground biomass production and $\mathrm{I}_{\text {cum }}$ were significant to a level of $P<0.001$ (Figure 4.4). The other tested structural attributes (fine root biomass, root length density, species richness) had no significant effect on $\mathrm{ET}_{\text {cum }}$, $\mathrm{I}_{\text {cum }}$ or WUE.

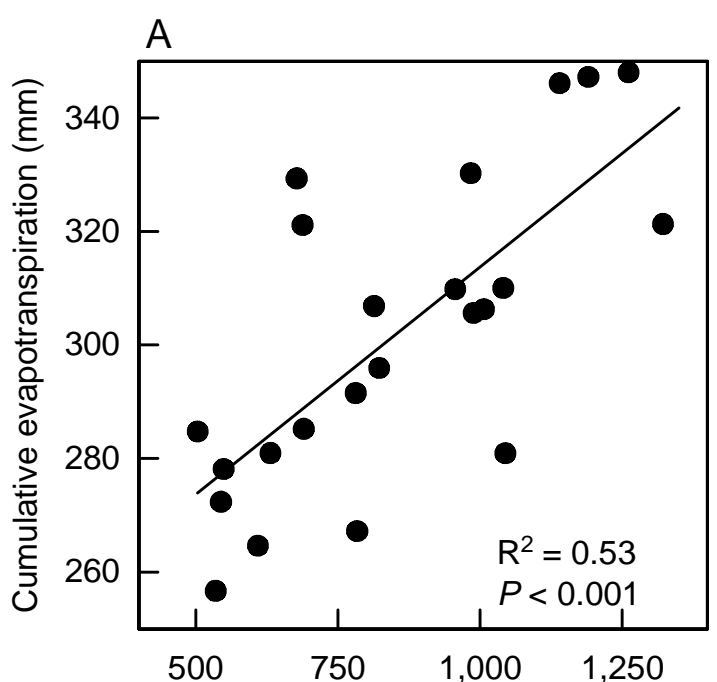

Aboveground biomass production $\left(\mathrm{g} \mathrm{DM} \mathrm{m}^{-2}\right)$

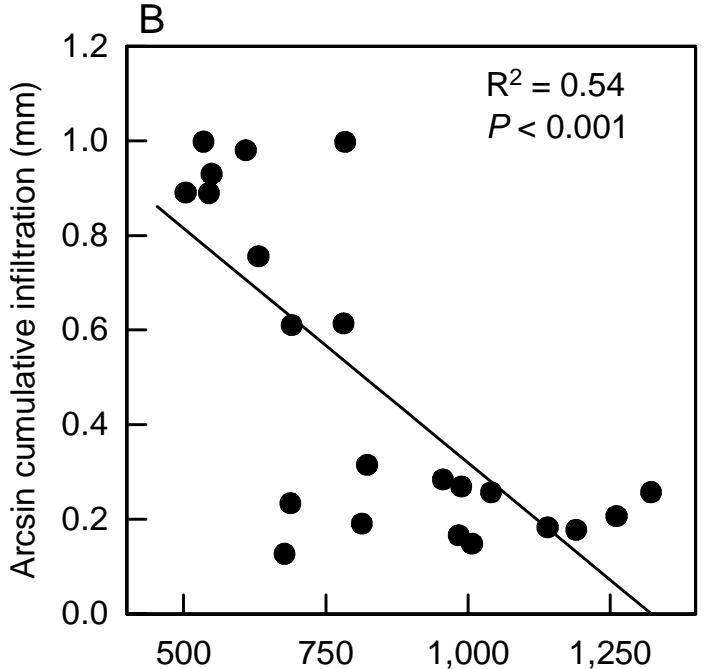

Aboveground biomass production $\left(\mathrm{g} \mathrm{DM} \mathrm{m}^{-2}\right)$

Figure 4.4: Relation between aboveground biomass production and cumulative evapotranspiration (A) or cumulative infiltration (B) in the 24 study plots (Pearson correlation). 


\subsection{Discussion}

\subsubsection{Abiotic and biotic controls of grassland evapotranspiration}

Climatic, edaphic and biotic factors are involved in the regulation of the transfer of water from the soil to the atmosphere through the processes of transpiration, soil evaporation and the evaporation of intercepted water. Our study suggests a dominant role of the atmospheric water vapor saturation deficit under the climatic factors. It had a much greater influence on ET than energy availability (approximated here by global radiation), which itself influences VPD through its effect on temperature.

Other studies on grassland ET similarly provided evidence of a dominant role of VPD in the control of the water vapor loss to the atmosphere (Wever et al. 2002, Wieser et al. 2008), even in alpine grasslands of very low vegetation height. With increasing soil water deficits, the dominant role of VPD diminishes and edaphic factors (soil moisture content or soil matrix potential, grain size distribution of the soil, distance to ground water level) and precipitation achieve a greater influence on grassland ET (Renger \& Strebel 1980, Burke et al. 1998, Meyers 2001). Thus, the lacking precipitation effect on the corresponding ET and I rates in a measuring interval underlines that water shortage had little influence on ET during the measurement period.

Vegetation may influence evapotranspiration through stand height and density, leaf area development, rooting depth and/or total root length, and stomatal control of leaf transpiration. Kristensen (1974) found a linear increase of ET up to leaf area indices of $5 \mathrm{~m}^{2} \mathrm{~m}^{-2}$ in agricultural fields. Because the measurement of grassland leaf area is labor-intensive and often inaccurate, grassland ET has frequently been related to aboveground biomass instead of LAI, yielding linear or curvilinear positive relationships (Sims \& Singh 1978, Montheith 1988, Polley et al. 2008, Verheyen et al. 2008). We used aboveground biomass production in the main vegetation period $(155 \mathrm{~d})$ and related it to the cumulative evapotranspiration and infiltration in this period, yielding coefficients of determination for these relationships of 0.53 (ET) and 0.54 (I). The rather tight correlation between aboveground biomass production and grassland ET is not paralleled by a similar dependence of ET on the size of the root system: we found no relation between $\mathrm{ET}_{\text {cum }}$ and the fine root biomass in the lysimeters or root length density. It appears that the size (or surface area) of the root system is not a limiting factor for the water uptake of the grassland at our site. 


\subsubsection{Effects of management on grassland evapotranspiration and infiltration}

It is a well established fact that fertilized grasslands have not only higher productivities, but also higher ET rates than unfertilized ones (e.g., Klapp 1971, Monteith 1988, Schulze et al. 1994). However, most fertilization trials in temperate meadows or pastures showed a substantial increase in yield, but only marginally higher ET rates (Wind 1954, Husemann \& Wesche 1964). A lysimeter study by Klapp (1971) on the effect of grassland fertilization which distinguished between $\mathrm{N}$ and PK fertilization showed that only $\mathrm{N}$ fertilization led to a significant increase in ET. The main fertilization effect in Klapp's (1971) study was a carbon allocation shift towards aboveground biomass, which however, had an only minor effect on evapotranspiration. Our results from a replicated fertilization experiment in a grassland with century-long management history are in agreement with the findings of these earlier studies. Aboveground biomass production increased upon moderate $\mathrm{N}$ fertilization $\left(180 \mathrm{~kg} \mathrm{ha}^{-1}\right)$ by $50-70 \%$ while ET rose only by $10-15 \%$.

Because $180 \mathrm{~kg} \mathrm{~N} \mathrm{ha}^{-1}$ is a typical $\mathrm{N}$ fertilizer dose in intensively used grassland in Central Europe, an increase in ET by $10-15 \%$ and a corresponding decrease in groundwater recharge by $20-40 \mathrm{~mm}$ in the vegetation period must be viewed as characteristic hydrological consequences of the increase in fertilizer application that has happened throughout Central Europe since the 1960s. Thus, the intensification of grassland management must have significantly decreased the water yield in regions with extended grassland area due to $\mathrm{N}$ effects on biomass and productivity, while the concurrent increase in mowing frequency apparently has not affected the grassland water balance.

In contrast to our second hypothesis, ET and I were not affected by the increase in cutting frequency from 1 to 3 per season in our experiment. This is due to the fact, that aboveground biomass production was not significantly different between the treatments with one and three cuttings. In fact, the first cut in May in the C3 treatment resulted in a reduced biomass at the time of the second cut in July. Since differences in aboveground biomass production were identified in this study as the only cause for differences in ET, it follows that different mowing frequencies had no influence on evapotranspiration. However, when considering longer time spans than done in our study, it is likely that the community composition of meadows with increased cutting frequencies will shift to species more tolerant to disturbance (Díaz et al. 1992, Craine et al. 2001), which might result in alterations of the water balance. 
More surprising than the lacking effect of frequent cutting on aboveground biomass production is the absence of a significant management effect on root biomass and root:shoot biomass ratio. It is generally assumed that repeated mowing and grazing cycles lead to a reduction of belowground plant biomass because assimilates are increasingly used for the formation of new shoots to replace the lost ones (e.g., Speidel \& Weiß 1972, Gass \& Oertli 1980, Dawson et al. 2000).

A logical consequence of the large increase in biomass production, but only slight increase in ET, upon $\mathrm{N}$ fertilization is that the water use efficiency of the meadow plants increased as well. Elevated foliar $\mathrm{N}$ concentrations result in a number of physiological and morphological alterations at the leaf level that may affect productivity and transpirative water loss differently. Higher $\mathrm{N}$ concentrations can result in higher assimilation rates per leaf area, but they also stimulate the formation of leaves with higher SLA and larger size, extending plant leaf area (Craine et al. 2001, Pontes et al. 2007). Both effects enhance growth.

Since a higher photosynthetic capacity is typically associated with higher leaf conductance (Schulze et al. 1994), transpiration rate should also increase with a higher foliar $\mathrm{N}$ concentration. Three explanations are possible for the only small increase in ET, but large increase in WUE upon $\mathrm{N}$ fertilization in our experiment: i) increased foliar $\mathrm{N}$ increases the carboxylation capacity of the photosynthetic machinery, thereby reducing the stomatal conductance needed to guarantee sufficient $\mathrm{CO}_{2}$ diffusion to the chloroplasts, or ii) a larger leaf area promotes $\mathrm{CO}_{2}$ assimilation more than transpiration at the stand level because a higher density of leaf area per canopy volume reduces the boundary layer conductance of the canopy which restricts ET more than $\mathrm{CO}_{2}$ uptake. iii) Another possible explanation is a reduction in the leaf area to plant biomass ratio in response to fertilization, thereby decreasing the ratio of transpiring to non transpiring above-ground tissues.

Gas exchange measurements to determine photosynthetic capacity at light saturation $\left(\mathrm{A}_{\max }\right)$ in the five most abundant species in the study plots (Agrostis capillaris L., Dactylis glomerata L., Festuca rubra L., Rumex acetosa L. and Trifolium repens L.) at the end of June 2009 showed a significantly higher leaf-level WUE (unit: $\mathrm{mg} \mathrm{CO}_{2}$ assimilated per $\mathrm{g} \mathrm{H}_{2} \mathrm{O}$ transpired) in fertilized than unfertilized plots (ANOVA: $\mathrm{F}=19.27, P<0.0001$ ). However, fertilized plants of a species exceeded unfertilized plants by no more than $25 \%$ in their leaflevel WUE which is less than the $50 \%$ increase in stand-level WUE observed between the NPK- and NPK + treatments by lysimetry. This result is support for the assumption that the WUE on the leaf level is only one reason for the higher WUE on the stand level in the fertilized plots, while a stand structure effect on the boundary layer conductivity for water 
vapor must also have contributed to the relative reduction in ET in the denser fertilized grass stands. Thus, we conclude that the higher WUE observed in fertilized grasslands is caused by a higher WUE on the leaf level which is enhanced by a physical reduction of transpiration in the stands with higher biomass production due to a more closed canopy that reduces turbulence.

\subsubsection{Conclusions}

In a two-factorial replicated experiment, that simulated the increase in $\mathrm{N}$ fertilization and cutting frequency in a temperate grassland as it has taken place over the past 50 years in many grasslands, we found increases in aboveground biomass production by $50-70 \%$ which were associated with increases in stand evapotranspiration by $10-15 \%$ and corresponding reductions in deep seepage and ground water recharge. This effect could be even larger because low-productive grassland species are increasingly replaced by high productive Ndemanding plants with higher specific leaf areas when $\mathrm{N}$ fertilizer amounts remain high (e.g., Tilman 1987, Poorter \& De Jong 1999). Because more than $70 \%$ of the grassland area in Central Europe has been transformed from extensive to intensive management in the past 50 years (Ellenberg \& Leuschner 2010), ground water recharge must have significantly decreased in those regions where grasslands are abundant. If the predicted reduction in summer precipitation, forecasted for parts of Central Europe, comes true in the course of climate change, the decrease in ground water recharge may even be more pronounced. The combination of these two effects may lead to a progressive aridization of certain Central European landscapes that are humid in recent times.

\subsection{Acknowledgements}

The authors wish to thank three anonymous reviewers for improving an earlier version of this manuscript. We thank Lars Köhler and Maximilian v. Fragstein und Niemsdorff for help with the installation of the lysimeters and Ina Hoeft for support during the measurements and data of soil water content. Ute Petersen provided us with data of fresh biomass. This study is part of the Cluster of Excellence 'Functional Biodiversity Research', funded by the Ministry of Science and Culture of Lower Saxony and the "Niedersächsisches Vorab". 


\subsection{References}

Buck,A.L. (1981) New equations for computing vapor-pressure and enhancement factor. Journal of Applied Meteorology, 20, 1527-1532.

Burke,I.C., Lauenroth,W.K., Vinton,M.A., Hook,P.B., Kelly,R.H., Epstein,H.E., Aguiar,M.R., Robles,M.D., Aguilera,M.O., Murphy,K.L. \& Gill,R.A. (1998) Plant-soil interactions in temperate grasslands. Biogeochemistry, 42, 121-143.

Craine,J.M., Froehle,J., Tilman,D.G., Wedin,D.A. \& Chapin,F.S. (2001) The relationships among root and leaf traits of 76 grassland species and relative abundance along fertility and disturbance gradients. Oikos, 93, 274-285.

Dawson,L.A., Graystone,S.J. \& Paterson,E. (2000) Effects of grazing on the roots and rhizosphere of grasses. Grassland Ecophysiology and Grazing Ecology. (ed. by G.Lemaire, J.Hodgson, A.de Moraes, C.Nabinger and P.C.De F.Carvalho), pp. 61-84. CABI Publishing, Wallingford.

Díaz,S., Acosta,A. \& Cabido,M. (1992) Morphological analysis of herbaceous communities under different grazing regimes. Journal of Vegetation Science, 3, 689-696.

Ellenberg,H. \& Leuschner,C. (2010) Vegetation Mitteleuropas mit den Alpen. $\left(6^{\text {th }}\right.$ ed.) Ulmer Verlag, Stuttgart.

Gass,P. \& Oertli,J.J. (1980) Durchwurzelungsvergleich zwischen Fettwiese und angrenzender Brachwiese. Zeitschrift für Pflanzenernährung und Bodenkunde, 143, 208-214.

Greenwood,E.A.N., Turner,N.C., Schulze,E.D., Watson,G.D. \& Venn,N.R. (1992) Groundwatermanagement through increased water-use by lupin crops. Journal of Hydrology, 134, 1-11.

Husemann,C. \& Wesche,J. (1964) Der Wasserhaushalt und die Wasserbilanz eines lehmigen Sandbodens nach Untersuchungen in wägbaren Lysimetergefäßen. Zeitschrift für Kulturtechnick und Flurbereinigung, 5, 364-389.

Klapp,E. (1971) Wiesen und Weiden: Eine Grünlandlehre. ( $4^{\text {th }}$ ed.) Parey-Verlag, Berlin/Hamburg.

Krahulec,F., Skálová,H., Herben,T., Hadincová,V., Wildová.R. \& Pecháčková,S. (2001) Vegetation changes following sheep grazing in abandoned mountain meadows. Applied Vegetation Science, 4, 97-102.

Kristensen,K.J. (1974) Actual evapotranspiration in relation to leaf area. Nordic Hydrology, 5, 173182.

Leuschner,C. (1987) Niederschlagsinterzeption und Verdunstung in einer Goldhaferwiese und in der Krautschicht eines Kalkbuchenwaldes. Verhandlungen der Gesellschaft für Ökologie, 16, 237 244.

Meyers,T.P. (2001) A comparison of summertime water and CO2 fluxes over rangeland for well watered and drought conditions. Agricultural and Forest Meteorology, 106, 205-214.

Monteith,J.L. (1988) Does transpiration limit the growth of vegetation or vice versa? Journal of Hydrology, 100, 57-68.

Polley,H.W., Johnson,H.B., Fay,P.A. \& Sanabria,J. (2008) Initial response of evapotranspiration from tallgrass prairie vegetation to $\mathrm{CO}_{2}$ at subambient to elevated concentrations. Functional Ecology, 22, 163-171. 
Pontes,L.D.S., Soussana,J.F., Louault,F., Andueza,D. \& Carrère,P. (2007) Leaf traits affect the aboveground productivity and quality of pasture grasses. Functional Ecology, 21, 844-853.

Poorter,H. \& De Jong,R. (1999) A comparison of specific leaf area, chemical composition and leaf construction costs of field plants from 15 habitats differing in productivity. New Phytologist, 143, 163-176.

Renger,M. \& Strebel,O. (1980) Jährliche Grundwasserneubildung in Abhängigkeit von Bodennutzung und Bodeneigenschaften. Wasser und Boden, 32, 362-366.

Rosset,M., Montani,M., Tanner,M. \& Fuhrer,J. (2001) Effects of abandonment on the energy balance and evapotranspiration of wet subalpine grassland. Agriculture Ecosystems \& Environment, 86, 277-286.

Sala,O.E., Chapin,F.S., Armesto,J.J., Berlow,E., Bloomfield,J., Dirzo,R., Huber-Sanwald,E., Huenneke,L.F., Jackson,R.B., Kinzig,A., Leemans,R., Lodge,D.M., Mooney,H.A., Oesterheld,M., Poff,N.L., Sykes,M.T., Walker,B.H., Walker,M. \& Wall,D.H. (2000) Global biodiversity scenarios for the year 2100. Science, 287, 1770-1774.

Schulze,E.D., Kelliher,F.M., Körner,C., Lloyd,J. \& Leuning,R. (1994) Relationships among maximum stomatal conductance, ecosystem surface conductance, carbon assimilation rate, and plant nitrogen nutrition - A global ecology scaling exercise. Annual Review of Ecology and Systematics, 25, 629-660.

Sims,P.L. \& Singh,J.S. (1978) Structure and function of 10 western North-American grasslands. 3. Net primary production, turnover and efficiencies of energy capture and water-use. Journal of Ecology, 66, 573-597.

Speidel,B. \& Weiss,A. (1972) Zur ober- und unterirdischen Stoffproduktion einer Goldhaferwiese bei verschiedener Düngung. Angewandte Botanik, 46, 75-93.

Tasser,E. \& Tappeiner,U. (2002) Impact of land use changes on mountain vegetation. Applied Vegetation Science, 5, 173-184.

Tilman,D. (1987) Secondary succession and the pattern of plant dominance along experimental nitrogen gradients. Ecological Monographs, 57, 189-214.

Verheyen,K., Bulteel,H., Palmborg,C., Olivie,B., Nijs,I., Raes,D. \& Muys,B. (2008) Can complementarity in water use help to explain diversity-productivity relationships in experimental grassland plots? Oecologia, 156, 351-361.

Vitousek,P.M., Mooney,H.A., Lubchenco,J. \& Melillo,J.M. (1997) Human domination of earth's ecosystems. Science, 277, 494-499.

Wesche,K., Krause,B., Culmsee,H. \& Leuschner,C. (2009) Veränderungen in der FlächenAusdehnung und Artenzusammensetzung des Feuchtgrünlandes in Norddeutschland seit den 1950er Jahren. Berichte der Reinhold-Tüxen-Gesellschaft, 21, 196-210.

Wever,L.A., Flanagan,L.B. \& Carlson,P.J. (2002) Seasonal and interannual variation in evapotranspiration, energy balance and surface conductance in a northern temperate grassland. Agricultural and Forest Meteorology, 112, 31-49.

Wieser,G., Hammerle,A. \& Wohlfahrt,G. (2008) The water balance of grassland ecosystems in the Austrian Alps. Arctic Antarctic and Alpine Research, 40, 439-445.

Wind,M.P.G. Incidence de la fertilisation azotée sur la consommation en eau des herbages. Conf. Eur. des Herbages. 211-214. 1954. Paris, OECE. 


\section{CHAPTER 5}

Management alters interspecific leaf trait relationships and trait-based species rankings in permanent meadows

Laura Rose, Marie Carolin Vogel, Dietrich Hertel, Christoph Leuschner 


\subsection{Abstract}

Question: Plant functional traits bear the potential to characterize ecosystem functioning and to predict ecosystem responses to environmental changes. i) Do trait responses to land-use intensification alter trait-based species rankings, and, ii) does land-use intensification alter relationships among leaf traits?

Location: Solling Mountains, Central Germany (Grassland management experiment GrassMan).

Methods: In two years with different weather conditions, we analyzed the specific leaf area (SLA) of eight grassland species and related it to leaf nitrogen per mass $\left(\mathrm{N}_{\text {mass }}\right)$ or area $\left(\mathrm{N}_{\text {area }}\right)$ in an old-growth grassland with two fertilization levels (none vs. NPK-fertilization, 180-30-100 $\mathrm{kg} \mathrm{ha}^{-1} \mathrm{yr}^{-1}$ ) and two cutting frequencies (one vs. three cuttings per season).

Results: NPK-fertilization led to a general increase in SLA, $\mathrm{N}_{\text {mass }}$ and $\mathrm{N}_{\text {area }}$ while the effect of altered cutting frequency on leaf traits was more species-specific. A dry period followed by a period of high precipitation led to higher values of all traits in 2010 compared to 2009. Species-specific responses to management significantly altered trait-based species rankings. A significant SLA-N $\mathrm{N}_{\text {mass }}$ relationship did occur in unfertilized plots, whereas the SLA-N $\mathrm{N}_{\text {area }}$ relationship was stronger in fertilized plots. This was mostly caused by a decrease in the among-species variation in $\mathrm{N}_{\text {mass }}$ upon fertilization.

Conclusions: These results indicate that the relationships between plant functional traits are not as consistent across different management regimes as was suggested by earlier studies. Management intensification in semi-natural temperate meadows may substantially alter traitbased species rankings due to individual species responses and may decrease functional trait variation. 


\subsection{Introduction}

Extensively managed temperate grasslands with low fertilizer input belong to the most species-rich plant communities of Europe, harboring up to 70 species per $20 \mathrm{~m}^{2}$ (Ellenberg \& Leuschner 2010). These assemblages are composed of a considerable diversity of growth and survival strategies, even though the species exist under similar environmental conditions close together. Recently, much research has been directed towards the identification and categorization of plant functional traits that are responsible for the efficiency of resource capture and utilization and thus, determine productivity (Díaz et al. 2004, Wright et al. 2004). This information is fundamental for understanding species effects on ecosystem processes and for predicting community dynamics under a changing environment and management (Hooper 1998, Chapin et al. 2000, Loreau et al. 2001). A number of key traits have been identified that are of primary importance for resource capture and use in higher plants across a broad range of life forms, habitat types and climate zones: Specific leaf area (SLA: leaf area per dry mass) and leaf nitrogen concentration, expressed either per leaf dry mass $\left(\mathrm{N}_{\text {mass }}\right)$ or leaf area $\left(\mathrm{N}_{\text {area }}\right)$. In both, global and local datasets, SLA and leaf $\mathrm{N}$ concentration were found to be quite accurate predictors of light-saturated photosynthesis $\left(\mathrm{A}_{\max }\right)$ and relative growth rate $(\mathrm{RGR})$, which indicates that these easily measured traits may also be useful for estimating productivity at the plant and perhaps the ecosystem level (e.g., Hunt \& Cornelissen 1997, Reich et al. 1998, Reich et al. 2003, Wright et al. 2004, Poorter et al. 2009). Moreover, it appeared that $\mathrm{N}_{\text {mass }}$ and photosynthetic $\mathrm{N}$ use efficiency (carbon gain per foliar $\mathrm{N}$ ) are scaling positively with SLA because, in plants with higher SLA, a larger proportion of foliar $\mathrm{N}$ is allocated to the photosynthetic machinery (Poorter \& Evans 1998, Wright et al. 2004, He et al. 2006). Consequently, mass-specific photosynthetic capacity typically increases with increasing SLA. $\mathrm{N}_{\text {mass }}$ may scale to other functional traits as well, as to leaf longevity (negative relation; e.g., Reich et al. 1997), leaf decomposability (positive relation; Berg \& McClaugherty 2003) and to leaf conductance and transpirative water loss (positive relation; Schulze et al. 1994) linking this trait to the cycles of carbon, water and nutrients. Thus, understanding the response of leaf morphology and leaf $\mathrm{N}$ content to environmental changes could help to predict ecosystem functions and services (such as productivity, litter decomposition and water cycling) under altered conditions from easily measurable plant traits. Moreover, if the relationships between these traits would persist across different scales (leaf - plant - community), relationships between trait-dependent ecosystem functions might 
be valid from the patch to the landscape. Because it is still a matter of debate whether massor area-based N concentration is the more general functional trait (e.g., Garnier et al. 1997, Ryser \& Eek 2000, Wright et al. 2005a, Ordoñez et al. 2009), we decided to investigate both $\mathrm{N}_{\text {mass }}$ and $\mathrm{N}_{\text {area }}$. Because $\mathrm{N}_{\text {mass }}$ is $\mathrm{N}_{\text {area }}$ times SLA, changes in the SLA- $\mathrm{N}_{\text {mass }}$ relationship will also change the SLA-N $\mathrm{N}_{\text {area }}$ relationship.

Leaf traits are modulated by climate and soil conditions, and also respond to management factors such as fertilization, mowing, grazing and drainage, resulting in a considerable plasticity of SLA, foliar $\mathrm{N}$ concentration and other traits used for functional classification (e.g., Díaz et al. 1992, Anderson \& Briske 1995, Quétier et al. 2007). Fertilization is known to increase SLA and leaf N concentration of grassland plants (e.g., Reich et al. 2003, Pontes et al. 2007, Ordoñez et al. 2009). Biomass removal by mowing or grazing is another key management factor in grasslands with the potential to alter plant functional traits, but leaf trait responses to high defoliation rates are less intensively studied in grassland plants. On the species level, both increases (Jaramillo \& Detling 1988) and decreases in foliar $\mathrm{N}$ concentration (Pontes et al. 2007) have been reported as a response to clipping, while the SLA of target species was found to be unaffected (Thorne \& Frank 2009). On the community level, intensive mowing regimes have been shown to increase the population means of SLA (Louault et al. 2005) and foliar N concentration (e.g., Burke et al. 1998, Bakker et al. 2009).

Grassland management has shifted since the 1960s and 1970s from extensive grazing and mowing regimes with one cutting per year to highly intensive pastures and meadows with three to six cuttings. Fertilization has increased from low- to high-input systems with up to 150-300 kg N fertilizer ha ${ }^{-1}$ added today (e.g., Vitousek et al. 1997, Sala et al. 2000, Tasser \& Tappeiner 2002, Ellenberg \& Leuschner 2010). These management changes are the likely cause of a general trend to grassland plants with higher SLA and leaf N concentration, i.e. with increased growth potential, and the profound species shifts that have been observed in many European meadows and pastures in the past decades (e.g. Krause et al. 2011).

Different plant species, even when occurring in the same grassland patch, may possess different adaptations to changes in environmental conditions and therefore could respond differently, or to a different degree, to altered growth conditions (Díaz et al. 1992, Fonseca et al. 2000). This might entail alteration in trait-based species rankings (Garnier et al. 2001), which so far have been assumed to remain constant under changing climatic conditions and land-use intensities (Cunningham et al. 1999, Poorter \& De Jong 1999, Wilson et al. 1999, Lamont et al. 2002, Pontes et al. 2007). No alteration in species ranking despite 
environmental change would be expected if all species responded in a similar direction and with a similar magnitude, or if the species changed their traits not significantly. A consistent functional species ranking, if valid in a broader context, would greatly facilitate the task of modeling community traits from species behavior. For instance, a positive SLA response to fertilization on the species level and a constant species ranking should result in a positive SLA response of similar magnitude on the community level.

However, it has been found that species rankings based on functional attributes can change under altered environmental conditions (Albert et al. 2010), raising doubt about the consistency assumption. If coexisting species are sufficiently different in their response of SLA and foliar $\mathrm{N}$ to management intensification, the alterations should have the potential to change not only trait-based species rankings, but also the strength of between-trait relationships. Trait inter-relationships were found not to be consistent across different sites and communities which mostly has been attributed to variation in sample size, but Wright et al. (2005b) pointed out that contrasts in leaf trait variation could be another possible explanation for site differences in such relationships. Land-use intensification typically reduces species richness and often simplifies vegetation structures and decreases functional trait divergence because the species composition changes over time (e.g., Wilson \& Shay 1990, Jacquemyn et al. 2003, Grime 2006, Maurer et al. 2006, Klimek et al. 2007, 2008). Ahead of shifts in community composition, the among-species variation in functional traits could decrease, thereby altering the relationship between key traits such as SLA, $\mathrm{N}_{\text {mass }}$ and $\mathrm{N}_{\text {area }}$.

Here, we present the results of a functional trait screening study in a managed montane grassland that was subjected to the full-factorial grassland management experiment entitled GrassMan. This experiment in permanent grasslands in the uplands of Central Germany simulates the management intensification from low to high intensity (one vs. three cuttings per season, no fertilization vs. $180 \mathrm{~kg} \mathrm{~N} \mathrm{ha}^{-1} \mathrm{yr}^{-1}$ ) that has shaped large parts of Central Europe's grassland in the last 50 years. By comparing the four treatments (cutting frequency $\mathrm{x}$ fertilization intensity) and studying two years with contrasting weather conditions, we investigated the variability of the three important leaf-level traits SLA, $\mathrm{N}_{\text {mass }}$ and $\mathrm{N}_{\text {area }}$ for the eight most abundant plant species representing two main functional groups (four grasses, four herbs) in order to analyze the influence of management on trait variation and trait relationships.

We tested the hypotheses that 
i) species-specific trait responses to land-use intensification alter trait-based species rankings, and, ii) land-use intensification alters correlated plant functional traits in a coherent manner, leading to constancy in leaf trait relationships.

\subsection{Material and methods}

\subsubsection{Study site, experimental design and climatic conditions}

The study was conducted in a matrix of meadow plots differing in management intensity in the context of the interdisciplinary GrassMan project of the University of Göttingen on the role of land-use intensification (Petersen et al. in press). The plots are located in the Solling Mountains, Central Germany (51 ${ }^{\circ} 44^{\prime} \mathrm{N}, 9^{\circ} 32^{\prime} \mathrm{E}, 490 \mathrm{~m}$ a.s.1.), at a permanent grassland site belonging to the university's experimental farm Relliehausen The grassland community is a nutrient-poor, montane, mesic-moist to moist Lolio-Cynosuretum on haplic Cambisols with a $\mathrm{pH}_{\mathrm{H} 2 \mathrm{O}}$ between 5.2 and 5.6 that had previously been used for extensive cattle grazing.

The full-factorial experimental design included two cutting frequencies and two NPKfertilization levels that were combined with the manipulation of plant diversity in three different herbicide treatments. All 12 treatments were replicated six times, leading to 72 plots of $15 \mathrm{~m} \times 15 \mathrm{~m}$ size that were arranged in a Latin rectangle. Fertilizer was applied on half of the plots $\left(\mathrm{NPK}+, 180 \mathrm{~kg} \mathrm{~N} \mathrm{ha}^{-1} \mathrm{yr}^{-1}\right.$ applied as a mix of $\mathrm{NH}_{4} \mathrm{NO}_{3}$ and $\mathrm{CaCO}_{3}, 74: 26 \mathrm{wt} / \mathrm{wt}$, $30 \mathrm{~kg} \mathrm{Pha}^{-1}$ and $107 \mathrm{~kg} \mathrm{~K} \mathrm{ha}^{-1}$ ), and the other half received no fertilizer (NPK-; Table 5A.1). Half of the plots were cut once in July $(\mathrm{C} 1)$ and half of them were cut three times per season (May, July and September; C3). To create a gradient in plant species diversity, one third of the plots was treated with a herbicide that decreased the dominance of monocots (-Mon treatment), one third was treated with herbicides that decreased the amount of dicots (-Dic treatment) and one third was left as a control (Co treatment). Herbicide application took place on July 31, 2008. The -Mon treatment reduced the proportion of grasses in the biomass yield from $72 \%$ to about $45 \%$, while the -Dic treatment resulted in a reduction of herbs and legumes from initially $28 \%$ of the biomass yield to about $8 \%$ on the plot scale in May 2009 (Petersen et al. in press). Species richness was unaffected in the plots treated by monocot reduction but was significantly decreased in the -Dic plots (from 17 to 13 species in relevés of $9 \mathrm{~m}^{2}$ ). Herbicide application neither decreased the vegetation cover of the swards nor did it increase the abundance of annual species due to a possible disturbance effect. Further, no 
herbicide effect on the biomass yield of the treated plots was detectable in spring 2009 when the measurements started; a possible disturbance-induced increase in the nitrate concentration in the percolating soil water was not detected (From et al. 2011, Petersen et al. in press). All measurements on plant performance started one year after the management regimes in the plots had been implemented in summer 2008.

Mean annual temperature at the site is $6.9^{\circ} \mathrm{C}$ and annual precipitation is $1031 \mathrm{~mm}$ (Deutscher Wetterdienst 1961-1990). The mean growing season air temperature (April to September) was higher than the long-term mean $\left(12^{\circ} \mathrm{C}\right)$ in $2009\left(14{ }^{\circ} \mathrm{C}\right)$ and in $2010\left(15^{\circ} \mathrm{C}\right.$, Table 5A.2). Particularly high temperatures occurred in 2009 in July, August and September and in 2010 in June, July and August. Precipitation from April to September totaled $388 \mathrm{~mm}$ in 2009 and $485 \mathrm{~mm}$ in 2010. Both figures are lower than the long-term mean for this period (529 mm). In 2010, a marked dry period occurred in June and July followed by a particularly moist August (26, 47 and $182 \mathrm{~mm}$ in June, July and August vs. long-term means of 108, 97 and $85 \mathrm{~mm}$ ). Global radiation ranged between 425 and $493 \mathrm{MJ} \mathrm{m}^{-2}$ (monthly sums) from April to August 2009, and declined in September to a value of $266 \mathrm{MJ} \mathrm{m}^{-2}$. In 2010, summer irradiance was higher in June and July (556 and $533 \mathrm{MJ} \mathrm{m}^{-2}$, respectively), but declined in August to a low value of $298 \mathrm{MJ} \mathrm{m}^{-2}$ (Table 5A.2). A comparison to long-term means was not possible.

\subsubsection{Leaf sampling}

Leaves of four grass species (Agrostis capillaris L., Dactylis glomerata L., Festuca rubra L., Poa humilis Ehrh. ex Hoffm.) and three non-legume herbs (Ranunculus repens L., Rumex acetosa L., Veronica chamaedrys L.) were sampled in all 72 plots; the legume Trifolium repens L. could be studied only in the -Mon and Co plots (48 plots) because it was virtually absent in the -Dic plots. The eight species chosen for study were selected according to their abundance (they belonged to the 10 most abundant species at the study site), the representation of three important functional groups (grasses, non-legume herbs and legumes) and their occurrence in all plots (not fulfilled in the case of T. repens). These eight species accounted on average for $88 \%$ of the standing biomass across all plots in August 2009 (U. Petersen, unpublished data).

All species are perennials that naturally occur in the grasslands of temperate Europe and are characterised by a high mowing tolerance (except for A. capillaris and $R$. acetosa that are 
classified as being only moderately tolerant, Dierschke \& Briemle 2002). The grasses included two tall species (D. glomerata and F. rubra, maximum height 110 and $90 \mathrm{~cm}$, respectively) and two taxa of low stature (A. capillaris and P. humilis, 40 and $30 \mathrm{~cm}$, respectively). The maximum height of the four herb species ranged from $100 \mathrm{~cm}$ (R. acetosa) to $60 \mathrm{~cm}$ (R. repens), $50 \mathrm{~cm}$ (T. repens) and $40 \mathrm{~cm}$ (V. chamaedrys; according to Grime et al. 1988).

Sampling took place three to five weeks after the latest cutting event in both years. In 2009, we sampled after the first cutting event (cutting of C3 plots only) between June 6 and June 16, and in 2010, we sampled after the second cutting event (cutting of all plots) between August 17 and 23 (Table 5A.1). Thus, leaves of C3 plots had the same age in both years, while in 2009, leaves in C1 plots may have developed before the cutting event and may have been older than the average leaf in the $\mathrm{C} 3$ plots. Thus, it cannot be excluded that recorded plant responses to the cutting regime in 2009 were partly also the result of altered light regimes in the sward and a higher leaf age, which can be excluded as influential factors in 2010. In all eight species, we sampled the youngest fully expanded leaf ( $V$. chamaedrys: two leaves) of one (2009) or two (2010) randomly selected plants per plot. The leaves were wrapped in wet paper towels and transferred to the laboratory in plastic bags, where they were stored in the refrigerator $\left(8^{\circ} \mathrm{C}\right)$ for at least one night (but not more than three days) for rehydration.

\subsubsection{Leaf trait analyses}

All leaves were analyzed for their leaf area using a flatbed scanner and the software WinFolia 2005b (Régent Instruments, Québec, Canada). Subsequently, the samples were dried $\left(70{ }^{\circ} \mathrm{C}, 80 \mathrm{~h}\right)$ and weighed to determine specific leaf area (SLA, $\left.\mathrm{cm}^{2} \mathrm{~g}^{-1}\right)$.

After weighing, the leaf material was homogenized by cutting the blade in small pieces and carefully mixing the fragments. Leaf $\mathrm{N}$ concentration was determined with a $\mathrm{C} / \mathrm{N}$ autoanalyzer (vario EL III; elementar Analysensysteme, Hanau, Germany) and expressed per leaf dry mass $\left(\mathrm{N}_{\text {mass }}, \mathrm{mmol} \mathrm{g}{ }^{-1}\right)$ and area $\left(\mathrm{N}_{\text {area }}, \mu \mathrm{mol} \mathrm{cm}{ }^{-2}\right)$. 


\subsubsection{Statistical analyses}

Statistical analyses were performed with SAS software version 8.02 (SAS Institute, Cary, NC, USA). All data were tested for normal distribution (Shapiro-Wilk test). A significance level of $P<0.05$ was used throughout.

We calculated general linear models for the leaf traits (SLA, $\mathrm{N}_{\text {mass }}, \mathrm{N}_{\text {area }}$ ). The models included cutting frequency, fertilization, species and the sampling year as well as all possible interactions as fixed effects, and column and row of the experimental site as random effects. Since we were interested only in management effects, the herbicide treatment was treated as a random effect. Before running the overall models that are presented here, we calculated models with the factors fertilization (fixed), cutting (fixed) and herbicide treatment (random, three levels) for each species separately to check for herbicide effects. This gave us the opportunity to separately calculate models for T. repens (which was not sampled in -Dic plots). Accordingly, herbicide treatment had no significant effect on any of the variables studied and therefore was deleted from the models. This allowed us to pool the data of a management treatment, resulting in 18 (T. repens: 12 ) plots that were treated as replicates. Differences between the four management treatments and the two years were analyzed by post-hoc Scheffé-tests.

Single linear regressions after Pearson were used to describe the interspecific relationships between specific leaf area and leaf $\mathrm{N}$ concentration $\left(\mathrm{N}_{\text {mass }}, \mathrm{N}_{\text {area }}\right)$ for the four management treatments. We visually checked for nonlinearity of the relationships. We calculated the inter-species coefficients of variation (standard deviation divided by mean) as a measure of interspecific trait variability across the eight species in the four management treatments. For this analysis, only data from the herbicide treatments -Mon and Co were used $(\mathrm{n}=12)$, since T. repens was rare in the -Dic plots and not sampled. Scheffé-tests were performed to test for differences between management treatments and years.

To quantify the impact of management on trait-based species rankings, we analyzed rank alterations caused by fertilization or different cutting frequencies. Species rankings in $\mathrm{C} 1$ and in NPK- plots were used as a reference, and rank alterations were calculated as absolute values. Statistically significant impacts on trait rankings were tested by performing onesample t-tests with the null-hypothesis of no rank alteration $(\mathrm{H} 0=0$, maximal possible mean rank alteration of eight species: 4). 


\subsection{Results}

\subsubsection{Species effects and interannual variation in leaf traits}

The factor explaining most of the variance in SLA and $\mathrm{N}_{\text {area }}$ was species identity (40 and $26 \%$ of the variation, respectively) while this factor was the second most important in case of the $\mathrm{N}_{\text {mass }}$ variance (19\%, Table 5.1). The small grass Festuca rubra had the lowest SLA values of all species, $V$. chamaedrys showed the lowest $\mathrm{N}_{\text {area }}$ values. The maximum values of SLA and $\mathrm{N}_{\text {area }}$ were reached by variable species in the different treatments (Table 5.1). In contrast, the legume $T$. repens was the species with highest $\mathrm{N}_{\text {mass }}$ values in seven of eight treatment $\mathrm{x}$ year combinations.

Table 5.1: Summary of general linear model results on the influence of cutting frequency (C), fertilization (NPK), species (Spec) and year (Y) and all possible interactions on specific leaf area (SLA) and mass- $\left(\mathrm{N}_{\text {mass }}\right)$ and area- $\left(\mathrm{N}_{\text {area }}\right)$ based foliar $\mathrm{N}$ concentrations ${ }^{\mathrm{a}}$.

\begin{tabular}{|c|c|c|c|c|c|c|c|c|c|}
\hline \multirow[b]{2}{*}{ Source } & \multicolumn{3}{|l|}{ SLA } & \multicolumn{3}{|l|}{$\mathbf{N}_{\text {mass }}$} & \multicolumn{3}{|l|}{$\mathbf{N}_{\text {area }}$} \\
\hline & V.e. $\%$ & $\mathrm{~F}$ & $P$ & V.e. $\%$ & $\mathrm{~F}$ & $P$ & V.e. $\%$ & $\mathrm{~F}$ & $P$ \\
\hline $\mathrm{C}$ & 0.37 & 14.76 & $* *$ & 0.01 & 0.78 & ns & 0.33 & 11.76 & $* * *$ \\
\hline NPK & 7.94 & 312.79 & $* *$ & 12.66 & 882.91 & $* * *$ & 4.35 & 152.72 & $* * *$ \\
\hline Spec & 39.89 & 196.53 & $* *$ & 18.80 & 163.95 & $* * *$ & 26.45 & 116.08 & $* * *$ \\
\hline Y & 14.63 & 576.57 & $* *$ & 45.75 & 3190.73 & $* * *$ & 19.31 & 678.03 & *** \\
\hline C*NPK & 0.10 & 4.01 & $*$ & 0.20 & 13.90 & $* * *$ & 0.07 & 2.53 & ns \\
\hline $\mathrm{C}^{*}$ Spec & 1.00 & 4.95 & $* *$ & 0.18 & 1.57 & $\mathrm{n}$ & 0.93 & 4.09 & $* * *$ \\
\hline $\mathrm{C}^{*} \mathrm{Y}$ & 0.34 & 13.41 & $* *$ & 1.48 & 103.27 & $* * *$ & 0.46 & 16.09 & $* * *$ \\
\hline NPK*Spec & 1.58 & 7.77 & $* *$ & 1.50 & 13.11 & $* * *$ & 5.95 & 26.13 & $* * *$ \\
\hline $\mathrm{NPK}^{*} \mathrm{Y}$ & 0.79 & 31.25 & $* *$ & 0.19 & 12.95 & $* * *$ & 4.37 & 153.49 & $* * *$ \\
\hline Spec*$^{*} Y$ & 1.75 & 9.83 & $* *$ & 1.58 & 15.76 & $* * *$ & 2.93 & 14.70 & $* * *$ \\
\hline Column & 0.89 & 7.05 & $* *$ & 0.69 & 9.61 & $* * *$ & 0.20 & 1.40 & ns \\
\hline Row & 0.66 & 5.23 & $* *$ & 0.04 & 0.53 & $\mathrm{~ns}$ & 0.62 & 4.36 & $* * *$ \\
\hline Model & 72.45 & 37.09 & $* *$ & 84.30 & 76.36 & $* * *$ & 69.10 & 31.51 & $* * *$ \\
\hline
\end{tabular}

${ }^{\mathrm{a}}$ V.e. $\%$ : percentage of variance explained, $* * *, * *, *: P<0.001,0.01,0.05$, respectively, ns: not significant. The study design variables column and row were included in the models as random effects. Higher interactions were not shown but none of it explained more than $2 \%$ of the variance. The explained variance and the $F$ values of the three most important source variables are given in bold letters.

With only few exceptions, the SLA, $\mathrm{N}_{\text {mass }}$ and $\mathrm{N}_{\text {area }}$ means were significantly different between 2009 and 2010 in a given species and treatment (see Tables 5A.3, A.4, A.5). Specific leaf area was on average $24 \%$ higher in 2010 than in 2009 across the eight species and $15 \%$ of the SLA variance was explained by the sampling year (Table 5.1). Exceptions from this rule were found for D. glomerata and $R$. repens in the NPK-C3 treatment, where no SLA increase from 2009 to 2010 was visible (Table 5A.3). Similarly, the $\mathrm{N}_{\text {mass }}$ values were higher in 
summer 2010 than in 2009 and the increase was even larger (significant in all cases except for D. glomerata in the NPK $+\mathrm{C} 3$ treatment, Table 5A.4); the sampling year explained $46 \%$ of the $\mathrm{N}_{\text {mass }}$ variance. The mean $\mathrm{N}_{\text {mass }}$ increase differed among the species and ranged from $33 \%$ in D. glomerata to $89 \%$ in $P$. humilis (average of all species: 64\%). The interannual variation was less pronounced in $\mathrm{N}_{\text {area }}$ with a mean increase of the values by $30 \%$ between 2009 and 2010 and only $19 \%$ of the $\mathrm{N}_{\text {area }}$ variance explained on average by the sampling year. In several cases (in particular in the fertilized plots), the interannual $\mathrm{N}_{\text {area }}$ change was not significant. In the case of D. glomerata, even a decrease from 2009 to 2010 was registered in the NPK $+\mathrm{C} 3$ plots (Table 5A.5).

\subsubsection{Fertilization effects on leaf traits}

Fertilization with $180 \mathrm{~kg} \mathrm{~N} \mathrm{ha}^{-1} \mathrm{yr}^{-1}$ led in most investigated species to a significant increase in SLA (about 18\% increase for the eight species) compared to unfertilized plots. The increase was, in most cases, independent of the cutting regime (C1 vs. C3) and sampling year, and explained $8 \%$ of SLA variance (Table 5.1). Exceptions to this pattern in 2009 were D. glomerata (no SLA increase), A. capillaris and R. acetosa (increase only in C1 plots) and F. rubra and R. repens (increase only in C3 plots, Table 5A.3).

Fertilization resulted in significantly increased mass-based foliar $\mathrm{N}$ concentrations $\left(\mathrm{N}_{\text {mass }}\right.$ ). The average $\mathrm{N}_{\text {mass }}$ increase of the eight species for the two years was $28 \%$. Thirteen percent of the $\mathrm{N}_{\text {mass }}$ variance was explained by fertilization (Table 5.1). The increase was significant except for T. repens in 2009 (no response) and F. rubra and T. repens in 2010 (increase only in certain treatments, Table 5A.4).

We found a less consistent effect of fertilization on area-based leaf $\mathrm{N}$ content $\left(\mathrm{N}_{\text {area }}\right)$ with a large interspecific and interannual contrast in response patterns $(6 \%$ of the variance explained by the fertilization $\mathrm{x}$ species interaction, Table 5.1). While most species showed a significant increase upon fertilization in 2009 (mean increase across species 30\% (Table 5A.5); exceptions: $R$. acetosa and T. repens), the majority of species responded with no change or even a $\mathrm{N}_{\text {area }}$ decrease in 2010. A significant increase was detected only in $A$. capillaris and D. glomerata (only $\mathrm{C} 1$ plots) while $R$. repens, T. repens and V. chamaedrys showed lower $\mathrm{N}_{\text {area }}$ values with fertilization than without it (only in $\mathrm{C} 3$ plots). 


\subsubsection{Effects of cutting on leaf traits}

In general, the effect of an increased cutting frequency (from one to three cuttings) on the studied leaf traits was less consistent among the eight species than the $\mathrm{N}$ fertilization effect and it differed between the two years (less than $1 \%$ variance explained by cutting alone, Table 5.1). In 2009, the SLA values of D. glomerata and $R$. repens, A. capillaris (only NPKplots) and F. rubra (only NPK+ plots) were significantly higher in C3 than in C1 plots, while T. repens, $R$. acetosa and $P$. humilis showed a lower SLA in C3 plots than in C1 plots (for the latter two species, only in NPK+ plots) (Table 5A.3). In 2010, D. glomerata, T. repens and V. chamaedrys had a lower SLA in C3 than in C1 plots with the NPK- treatment, and the SLA of F. rubra was lower in $\mathrm{NPK}+\mathrm{C} 3$ plots than in $\mathrm{NPK}+\mathrm{C} 1$ plots.

Similarly, we found no consistent effect of the cutting regime on the foliar $\mathrm{N}$ concentrations of the eight species, neither for $\mathrm{N}_{\text {mass }}$ nor for $\mathrm{N}_{\text {area }}$ (Tables S4 and S5). In 2009, a portion of the species (four in the unfertilized and two in the fertilized plots) responded with a significant increase in $\mathrm{N}_{\text {mass }}$ to an increased cutting frequency, while in 2010, all species (except for $T$. repens) showed a significant decrease of $\mathrm{N}_{\text {mass }}$ when cutting was increased from one to three cuttings per year. However, with the exception of D. glomerata, this decrease was restricted to the fertilized plots with generally higher $\mathrm{N}_{\text {mass }}$ values than the unfertilized ones.

The response of $\mathrm{N}_{\text {area }}$ to high cutting frequencies was positive in the case of $A$. capillaris, P. humilis, $R$. acetosa and T. repens (only in NPK+ plots), R. repens (only in NPKplots) and V. chamaedrys in both fertilization treatments in 2009 (Table 5A.5). In 2010, we found a negative effect of increasing the cutting frequency in NPK + plots, but not in NPKplots, for A. capillaris, D. glomerata, P. humilis and V. chamaedrys, while T. repens showed a positive $\mathrm{N}_{\text {area }}$ response to high cutting frequencies (only in unfertilized plots).

\subsubsection{Relation between SLA and leaf nitrogen status}

Specific leaf area and mass-based nitrogen concentration $\left(\mathrm{N}_{\text {mass }}\right)$ showed a positive, SLA and area-based $\mathrm{N}$ a negative relationship across the eight species (Figures 1, 2). The tightness of the correlations depended strongly on the fertilizer amount. Significant SLA-N $\mathrm{N}_{\text {mass }}$ relationships appeared only in unfertilized plots (Fugure 5.1). They were stronger in 2009 $\left(R^{2}=0.44,0.50 ; \mathrm{C} 3, \mathrm{C} 1\right.$, respectively $)$ than in $2010\left(R^{2}=0.32,0.43 ; \mathrm{C} 3, \mathrm{C} 1\right.$, respectively; in C3 plots only marginally significant). 


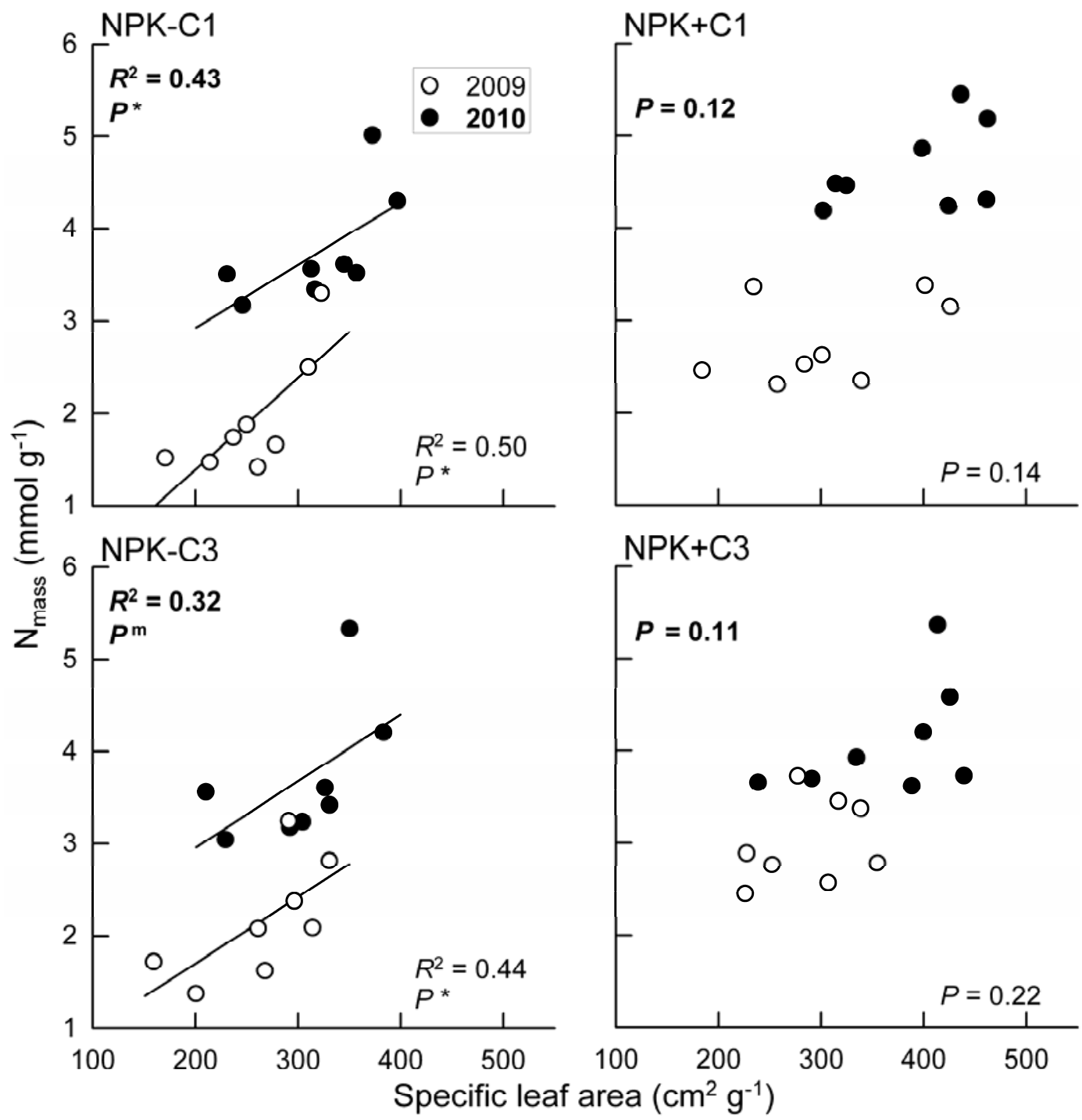

Figure 5.1: Relationship between specific leaf area and mass-based leaf $\mathrm{N}$ concentration of eight grassland species in June 2009 and August 2010 in the four management treatments $(\mathrm{n}=16-18$ and 10-12 [T. repens]). Treatments differ in NPK-fertilization (NPK+/NPK-) and cutting frequency (C1 / C3). $R$ : Pearson's correlation coefficient; *, m: $P<0.05,0.1$, respectively.

In contrast, in unfertilized plots, a significant SLA- $\mathrm{N}_{\text {area }}$ relationship could be detected only in the $\mathrm{C} 1$ plots in $2010\left(R^{2}=0.40\right)$, but strong SLA-N $\mathrm{N}_{\text {area }}$ relationships appeared in fertilized plots (Fugure 5.2). They were stronger in $2010\left(R^{2}=0.62,0.73 ; \mathrm{C} 3, \mathrm{C} 1\right.$, respectively) than in $2009\left(R^{2}=0.44,0.57\right.$; C3, C1, respectively).

Similar relationships between SLA and leaf nitrogen appeared when the data of the plant individuals instead of species means were correlated.(all relationships significant at $P<0.01$ ). In the unfertilized plots of both cutting regimes, the SLA-N $\mathrm{N}_{\text {mass }}$ relationships were stronger than in the fertilized plots (significantly higher $\mathrm{R}^{2}$ and steeper slope in both years; $\mathrm{t}$-test: $P<0.05)$. In contrast, the SLA-N $\mathrm{N}_{\text {area }}$ relation was stronger in the fertilized than the unfertilized plots (significant fertilization effect on $\mathrm{R}^{2}$ values; t-test: $P<0.05$ ). This difference was only visible when all species were pooled; single-species analyses did not show the 
fertilization effect on the tightness of the SLA-N $\mathrm{N}_{\text {area }}$ and SLA-N $\mathrm{N}_{\text {mass }}$ relationship (data not shown).

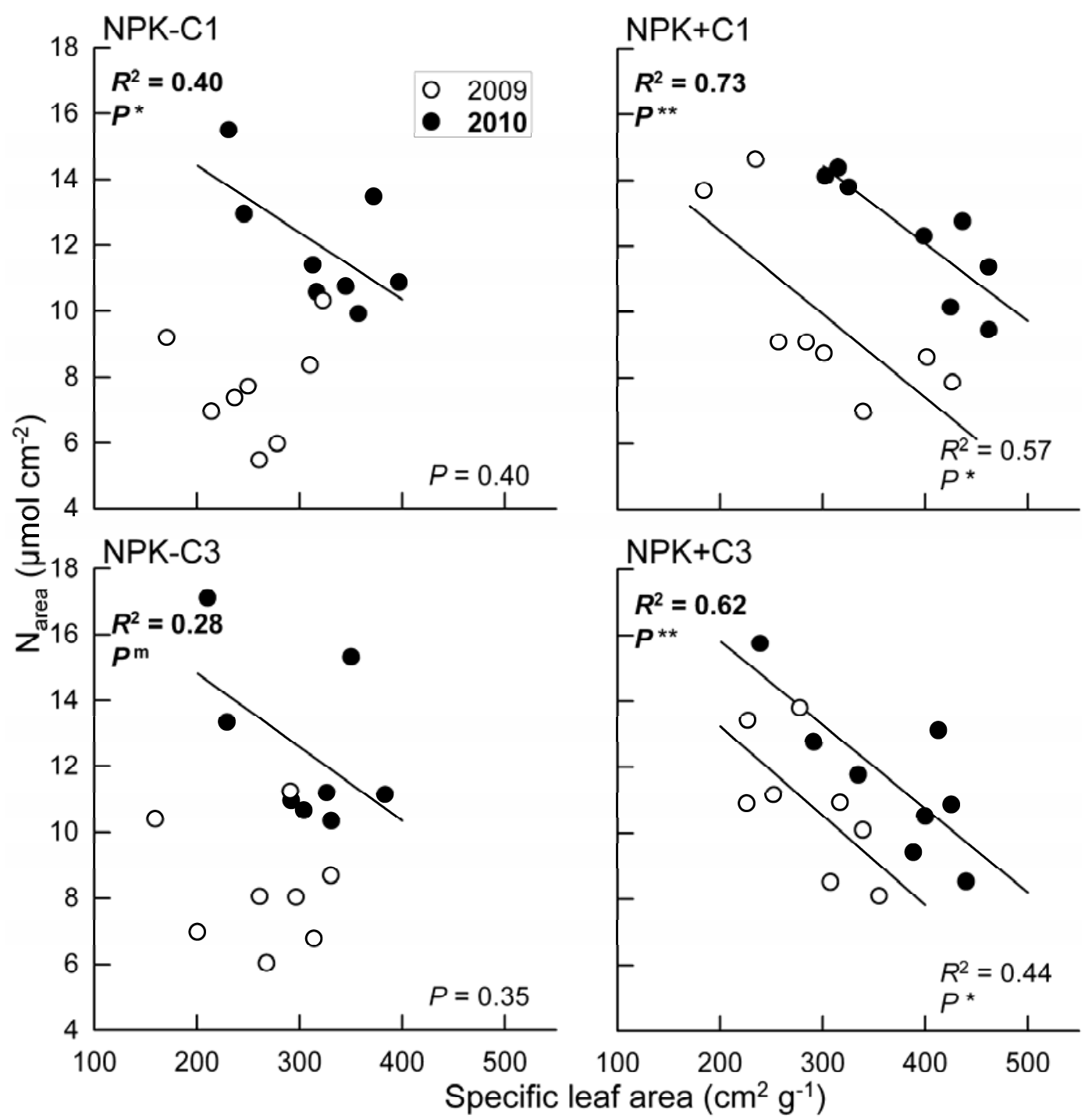

Figure 5.2: Relationship between specific leaf area and area-based leaf $\mathrm{N}$ concentration of eight grassland species in June 2009 and August 2010 in the four management treatments $(\mathrm{n}=16-18$ and 10-12 [T. repens]). Treatments differ in NPK-fertilization (NPK+/NPK-) and cutting frequency $(\mathrm{C} 1 / \mathrm{C} 3)$. $R$ : Pearson's correlation coefficient; $* *, *$ m: $P<0.01,0.05,0.1$, respectively.

\subsubsection{Interspecific trait variation and species ranking: influence of management}

The interspecific variation of the studied leaf traits across the eight species was not systematically influenced by the management regime in the case of SLA and $\mathrm{N}_{\text {area }}$ (Table 5.2). However, the interspecific variation of $\mathrm{N}_{\text {mass }}$ was smaller in fertilized than in unfertilized plots, and in eight of 12 trait $\mathrm{x}$ treatment combinations, the interspecific variation was significantly higher in 2009 than in 2010, when SLA, $\mathrm{N}_{\text {mass }}$ and $\mathrm{N}_{\text {area }}$ were generally lower. A 
test for management effects on intraspecific variation (using species as a replicate) did not reveal any management effect (data not shown).

Table 5.2: Coefficients of the interspecific variation of the specific leaf area and mass-based and area-based $\mathrm{N}$ concentrations among the eight species in the four management treatments in the years 2009 and $2010^{\mathrm{a}}$.

\begin{tabular}{|c|c|c|c|c|c|c|c|}
\hline & \multicolumn{4}{|l|}{2009} & \multicolumn{3}{|l|}{2010} \\
\hline & Mean & & SE & & Mean & SE & \\
\hline SLA & & & & & & & \\
\hline NPK-C1 & 0.25 & \pm & 0.02 & $\mathrm{aA}$ & 0.22 & \pm 0.01 & $\mathrm{aA}$ \\
\hline NPK & 0.30 & \pm & 0.03 & & 0.19 & \pm 0.01 & $1 \mathrm{aA}^{*}$ \\
\hline NPK & 0.27 & \pm & 0.02 & $\mathrm{a}$ & 0.21 & \pm 0.01 & $1 \mathrm{aA}^{*}$ \\
\hline $\mathrm{NPK}+\mathrm{C} 3$ & 0.23 & \pm & 0.01 & $\mathrm{a} A$ & 0.21 & \pm 0.01 & $1 \mathrm{aA}$ \\
\hline $\mathbf{N}_{\text {mass }}$ & & & & & & & \\
\hline NPK & 0.36 & \pm & 0.02 & $\mathrm{aA}$ & 0.19 & \pm 0.01 & $1 \mathrm{aA}^{*}$ \\
\hline $\mathrm{NPK}+\mathrm{C} 1$ & 0.20 & \pm & 0.02 & $\mathrm{bA}$ & 0.14 & \pm 0.01 & $1 \mathrm{bA}^{*}$ \\
\hline NPK-C3 & 0.32 & \pm & 0.02 & $\mathrm{a}$ & 0.23 & \pm 0.01 & $1 \mathrm{aA}^{*}$ \\
\hline $\mathrm{NPK}+\mathrm{C} 3$ & 0.21 & \pm & 0.02 & $\mathrm{bA}$ & 0.18 & \pm 0.02 & $2 b A$ \\
\hline & & & & & & & \\
\hline & 0.29 & \pm & 0.02 & $\mathrm{aA}$ & 0.21 & \pm 0.02 & $2 \mathrm{aA}^{*}$ \\
\hline $\mathrm{NPK}+\mathrm{C} 1$ & 0.31 & \pm & 0.02 & $\mathrm{aA}$ & 0.18 & \pm 0.01 & 1 aA* \\
\hline NPK-C3 & 0.26 & \pm & 0.01 & $\mathrm{aA}$ & 0.25 & \pm 0.01 & $1 \mathrm{aA}$ \\
\hline $\mathrm{NPK}+\mathrm{C} 3$ & 0.25 & \pm & 0.02 & $\mathrm{aA}$ & 0.20 & \pm 0.02 & $2 \mathrm{aA}^{*}$ \\
\hline
\end{tabular}

\begin{abstract}
${ }^{a}$ Different lower-case letters indicate significant differences between the two fertilization treatments, different capital letters indicate significant differences between the two cutting treatments within a given sampling period, asterisks denote significant differences between the years within a management treatment (Scheffé test, $P<0.05, \mathrm{n}=12$ ).
\end{abstract}

Species ranking based on the functional leaf traits SLA, $\mathrm{N}_{\text {mass }}$ and $\mathrm{N}_{\text {area }}$ was significantly altered by both fertilization and altered cutting frequency (Table 5.3). Table 5.4 shows that fertilization and cutting frequency as sources of rank alterations resulted in significant rank shifts of at least 0.37 steps and at most 2.25 steps (i.e., mean rank alterations per species of 0.37 and 2.25 among the eight species; maximum possible shift: 4), when different cutting or fertilization treatments were compared.

SLA-based ranks were altered by fertilization by 1 and 0.5 steps (2009 and 2010, respectively). Rank shifts (SLA-based rankings) caused by alterations in cutting frequency were stronger in fertilized plots and also stronger in 2009 ( 1 and 1.5 steps in the NPK- and $\mathrm{NPK}+$ treatments, respectively) than in 2010 ( 0 and 0.5 steps) (Table 5.4). 
Table 5.3: Rankings of eight grassland species based on the leaf traits SLA, $N_{\text {mass }}$ and $N_{\text {area }}$ in the four management treatments in 2009 and $2010^{\mathrm{a}}$.

\begin{tabular}{|c|c|c|c|c|c|c|c|c|c|c|c|c|c|c|c|c|}
\hline & \multicolumn{8}{|c|}{2009} & \multicolumn{8}{|c|}{2010} \\
\hline & 1 & 2 & 3 & 4 & 5 & 6 & 7 & 8 & 1 & 2 & 3 & 4 & 5 & 6 & 7 & 8 \\
\hline \multicolumn{17}{|l|}{ SLA } \\
\hline NPK-C1 & $\mathrm{Fe}$ & Po & $\mathrm{Ag}$ & $\mathrm{Da}$ & $\mathrm{Ve}$ & $\mathrm{Ra}$ & $\mathrm{Ru}$ & $\operatorname{Tr}$ & $\mathrm{Fe}$ & Po & $\mathrm{Da}$ & $\mathrm{Ra}$ & $\mathrm{Ag}$ & $\mathrm{Ve}$ & $\operatorname{Tr}$ & $\mathrm{Ru}$ \\
\hline $\mathrm{NPK}+\mathrm{C} 1$ & $\mathrm{Fe}$ & $\mathrm{Da}$ & Po & $\mathrm{Ag}$ & $\mathrm{Ra}$ & $\operatorname{Tr}$ & $\mathrm{Ru}$ & $\mathrm{Ve}$ & $\mathrm{Fe}$ & Po & $\mathrm{Da}$ & $\mathrm{Ag}$ & $\mathrm{Ra}$ & $\operatorname{Tr}$ & $\mathrm{Ve}$ & $\mathrm{Ru}$ \\
\hline NPK-C3 & $\mathrm{Fe}$ & $\mathrm{Po}$ & $\mathrm{Ag}$ & $\mathrm{Ve}$ & $\operatorname{Tr}$ & $\mathrm{Da}$ & $\mathrm{Ra}$ & $\mathrm{Ru}$ & $\mathrm{Fe}$ & Po & $\mathrm{Da}$ & $\mathrm{Ra}$ & $\mathrm{Ag}$ & $\mathrm{Ve}$ & $\operatorname{Tr}$ & $\mathrm{Ru}$ \\
\hline $\mathrm{NPK}+\mathrm{C} 3$ & Po & $\mathrm{Fe}$ & $\mathrm{Ag}$ & $\mathrm{Da}$ & $\mathrm{Ve}$ & $\operatorname{Tr}$ & $\mathrm{Ru}$ & $\mathrm{Ra}$ & $\mathrm{Fe}$ & Po & $\mathrm{Da}$ & $\mathrm{Ra}$ & $\mathrm{Ag}$ & $\operatorname{Tr}$ & $\mathrm{Ru}$ & $\mathrm{Ve}$ \\
\hline \multicolumn{17}{|l|}{$\mathrm{N}_{\text {mass }}$} \\
\hline NPK-C1 & $\mathrm{Ve}$ & $\mathrm{Po}$ & $\mathrm{Fe}$ & $\mathrm{Ra}$ & $\mathrm{Ag}$ & $\mathrm{Da}$ & $\mathrm{Ru}$ & $\operatorname{Tr}$ & Po & $\mathrm{Ra}$ & $\mathrm{Fe}$ & $\mathrm{Ve}$ & $\mathrm{Da}$ & $\mathrm{Ag}$ & $\mathrm{Ru}$ & $\operatorname{Tr}$ \\
\hline $\mathrm{NPK}+\mathrm{C} 1$ & Po & $\mathrm{Ve}$ & $\mathrm{Fe}$ & $\mathrm{Ag}$ & $\mathrm{Ra}$ & $\mathrm{Ru}$ & $\mathrm{Da}$ & $\operatorname{Tr}$ & $\mathrm{Fe}$ & $\mathrm{Ra}$ & $\mathrm{Ve}$ & $\mathrm{Da}$ & Po & $\mathrm{Ag}$ & $\mathrm{Ru}$ & $\operatorname{Tr}$ \\
\hline NPK-C3 & Po & $\mathrm{Ve}$ & $\mathrm{Fe}$ & $\mathrm{Ag}$ & $\mathrm{Ra}$ & $\mathrm{Da}$ & $\mathrm{Ru}$ & $\operatorname{Tr}$ & Po & $\mathrm{Da}$ & $\mathrm{Ra}$ & $\mathrm{Ve}$ & $\mathrm{Fe}$ & $\mathrm{Ag}$ & $\mathrm{Ru}$ & $\operatorname{Tr}$ \\
\hline $\mathrm{NPK}+\mathrm{C} 3$ & Po & $\mathrm{Ve}$ & $\mathrm{Ag}$ & $\mathrm{Ra}$ & $\mathrm{Fe}$ & $\mathrm{Ru}$ & $\operatorname{Tr}$ & $\mathrm{Da}$ & $\mathrm{Ra}$ & $\mathrm{Fe}$ & Po & $\mathrm{Ve}$ & $\mathrm{Da}$ & $\mathrm{Ag}$ & $\mathrm{Ru}$ & $\operatorname{Tr}$ \\
\hline \multicolumn{17}{|l|}{$\mathrm{N}_{\text {area }}$} \\
\hline NPK-C1 & $\mathrm{Ve}$ & $\mathrm{Ra}$ & Po & $\mathrm{Ag}$ & $\mathrm{Da}$ & $\mathrm{Ru}$ & $\mathrm{Fe}$ & $\operatorname{Tr}$ & $\mathrm{Ve}$ & $\mathrm{Ra}$ & $\mathrm{Ag}$ & $\mathrm{Ru}$ & $\mathrm{Da}$ & Po & $\operatorname{Tr}$ & $\mathrm{Fe}$ \\
\hline $\mathrm{NPK}+\mathrm{C} 1$ & Ve & $\mathrm{Ru}$ & $\operatorname{Tr}$ & $\mathrm{Ra}$ & $\mathrm{Ag}$ & Po & $\mathrm{Fe}$ & $\mathrm{Da}$ & Ve & $\mathrm{Ra}$ & $\mathrm{Ru}$ & $\mathrm{Ag}$ & $\operatorname{Tr}$ & $\mathrm{Da}$ & $\mathrm{Fe}$ & Po \\
\hline NPK-C3 & $\mathrm{Ve}$ & $\mathrm{Ra}$ & Po & $\mathrm{Da}$ & $\mathrm{Ag}$ & $\mathrm{Ru}$ & $\mathrm{Fe}$ & $\operatorname{Tr}$ & $\mathrm{Ve}$ & $\mathrm{Ra}$ & $\mathrm{Da}$ & $\mathrm{Ru}$ & $\mathrm{Ag}$ & Po & $\operatorname{Tr}$ & $\mathrm{Fe}$ \\
\hline $\mathrm{NPK}+\mathrm{C} 3$ & $\mathrm{Ra}$ & $\mathrm{Ve}$ & $\mathrm{Ru}$ & Po & $\operatorname{Tr}$ & $\mathrm{Ag}$ & $\mathrm{Fe}$ & $\mathrm{Da}$ & $\mathrm{Ve}$ & $\mathrm{Ra}$ & $\mathrm{Ag}$ & $\mathrm{Ru}$ & $\mathrm{Da}$ & Po & $\mathrm{Tr}$ & $\mathrm{Fe}$ \\
\hline
\end{tabular}

Alterations of $\mathrm{N}_{\text {mass }}$-based species rankings caused by fertilization were less pronounced in 2009 ( 0.75 and 1.0 steps in the C1 and C3 treatments, respectively) than in 2010 (1.0 and 1.25 steps; $\mathrm{C} 1$ not significant). Changes in the cutting frequency caused rank shifts between 0.5 and 0.75 steps (Table 5.4).

The impact of fertilization on $\mathrm{N}_{\text {area }}$-based species rankings was stronger in 2009 than in 2010 (shift by 2.0 and 0.75 steps, respectively). The cutting frequency had a significant effect

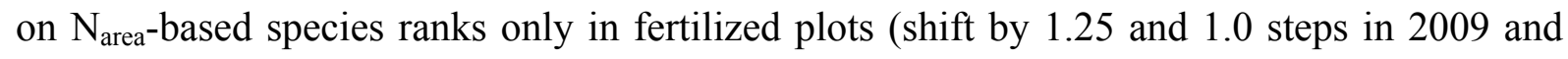
2010, respectively, Table 5.4). 
Table 5.4: Mean alteration (shift in steps) of SLA-, $\mathrm{N}_{\text {mass }}$ - and $\mathrm{N}_{\text {area }}$-based species ranks in the eight species caused by fertilization or cutting frequency (means $\pm \mathrm{SE}$ ) . For explanation see text.

\begin{tabular}{|c|c|c|c|c|c|c|}
\hline \multirow[t]{2}{*}{ Source } & \multicolumn{3}{|c|}{ Fertilization } & \multicolumn{3}{|c|}{ Cutting frequency } \\
\hline & Mean & $\pm \mathrm{SE}$ & $P$ & Mean & $\pm \mathrm{SE}$ & $P$ \\
\hline \multicolumn{7}{|l|}{ SLA } \\
\hline C1 2009 & 1 & \pm 0.19 & $* *$ & & & \\
\hline C3 2009 & 1 & \pm 0.19 & $* *$ & & & \\
\hline C1 2010 & 0.5 & \pm 0.19 & $*$ & & & \\
\hline C3 2010 & 0.5 & \pm 0.27 & ns & & & \\
\hline NPK- 2009 & & & & 1 & \pm 0.38 & $*$ \\
\hline NPK+ 2009 & & & & 1.5 & \pm 0.27 & $* * *$ \\
\hline NPK- 2010 & & & & 0 & \pm 0.00 & ns \\
\hline $\mathrm{NPK}+2010$ & & & & 0.5 & \pm 0.19 & $*$ \\
\hline \multicolumn{7}{|l|}{$\mathrm{N}_{\text {mass }}$} \\
\hline C1 2009 & 0.75 & \pm 0.16 & $* *$ & & & \\
\hline C3 2009 & 1 & \pm 0.27 & $* *$ & & & \\
\hline C1 2010 & 1 & \pm 0.50 & ns & & & \\
\hline C3 2010 & 1.25 & \pm 0.49 & $*$ & & & \\
\hline NPK- 2009 & & & & 0.5 & \pm 0.19 & $*$ \\
\hline $\mathrm{NPK}+2009$ & & & & 0.75 & \pm 0.25 & $*$ \\
\hline NPK- 2010 & & & & 0.75 & \pm 0.41 & ns \\
\hline $\mathrm{NPK}+2010$ & & & & 0.75 & \pm 0.25 & $*$ \\
\hline \multicolumn{7}{|l|}{$\mathrm{N}_{\text {area }}$} \\
\hline C1 2009 & 2.25 & \pm 0.65 & $*$ & & & \\
\hline C3 2009 & 1.75 & \pm 0.49 & $* *$ & & & \\
\hline C1 2010 & 1 & \pm 0.27 & $* *$ & & & \\
\hline C3 2010 & 0.5 & \pm 0.33 & ns & & & \\
\hline NPK- 2009 & & & & 0.25 & \pm 0.16 & ns \\
\hline $\mathrm{NPK}+2009$ & & & & 1.25 & \pm 0.37 & $*$ \\
\hline NPK- 2010 & & & & 0.5 & \pm 0.33 & $\mathrm{~ns}$ \\
\hline $\mathrm{NPK}+2010$ & & 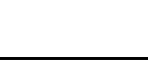 & & 1 & \pm 0.27 & $* *$ \\
\hline
\end{tabular}




\subsection{Discussion}

\subsubsection{Causes of interannual trait variation}

All three investigated leaf traits (SLA, $\mathrm{N}_{\text {mass }}$ and $\mathrm{N}_{\text {area }}$ ) reached higher values in 2010 than in 2009 with a few unsystematic exceptions. In our study, year effects on leaf traits could have been caused by any of three different mechanisms: first, possible differences in leaf age between $\mathrm{C} 1$ plots in 2009 and $\mathrm{C} 1$ plots in 2010; second, differences in the strength or direction of the cutting effect (possibly altered light conditions and biomass loss in 2009); and third, differences in the climatic conditions during leaf development. The first two mechanisms would have increased the treatment-dependent interannual variability: trait variation due to leaf age inconsistency should have occurred only in $\mathrm{C} 1$ plots, and trait variation due to differences in the light regime should also have led to stronger changes in $\mathrm{C} 1$ plots. Variation in climatic conditions, on the other hand, should lead to a uniform trait alteration across all treatments.

The two study years differed markedly in mean daily precipitation (1.1 vs. $2.3 \mathrm{~mm}$ in 2009 and 2010, respectively), mean daily radiation (9.5 vs. $6.3 \mathrm{MJ} \mathrm{m}^{-2}$ in 2009 and 2010 , respectively) and mean temperature (12.5 vs. $16.9^{\circ} \mathrm{C}$ in 2009 and 2010 , respectively) during the four weeks prior to leaf sampling. These differences are most likely the reason for higher SLA values in 2010 compared to 2009 , since low radiation as well as ample water supply and elevated air temperatures are known to increase SLA (Abrams et al. 1994, Ryser \& Eek 2000, Lamont et al. 2002, Poorter et al. 2009, Long et al. 2011). Furthermore, the July hay yields at our study site were strongly decreased due to a drought period in June and July 2010 (Table 5A.6). This might have reduced the nutrient loss with biomass export at the second harvest and, thus, improved nitrogen availability for regrowth as indicated by the increased $\mathrm{N}_{\text {mass }}$ values in 2010 as compared to 2009. Additionally, nitrogen supply in August 2010 may have been increased by a higher soil moisture, which has the potential to facilitate nutrient uptake (Larsen et al. 2011). In cases, where both SLA and $\mathrm{N}_{\text {mass }}$ are increasing, $\mathrm{N}_{\text {area }}$ does only increase when the $\mathrm{N}_{\text {mass }}$ value is raised to a greater extent than the SLA value.

The only treatment effect on the interannual variation in SLA was found for $R$. repens, where SLA values were higher in 2010 only in $\mathrm{C} 1$ plots but not in $\mathrm{C} 1$ plots. The reason for the different behavior of the treatments were higher SLA values in $\mathrm{C} 3$ than in $\mathrm{C} 1$ plots in 2009 but not in 2010, thereby reducing the climate influence on SLA in the C3 plots. We speculate that, in 2009, the leaves in the C1 plots may have been on average older than the 
leaves in the C3 plots, which was not the case in 2010. Thus, the observed interannual SLA pattern may have been caused by leaf aging effects, since older leaves of perennial herbs typically have lower SLA values than younger leaves (Dubey et al. 2011).

\subsubsection{Inconsistency of trait-based species ranking}

The main functional distinction in our species sample was the contrast between each four monocotyledonous (grasses) and dicotyledonous (herbs) species, which differed with respect to SLA (mostly lower values in the grasses) but not in leaf $\mathrm{N}$ concentration. More important, grasses and herbs exhibited no different response patterns to management in our experiment, even though the functional difference between the two functional groups has often been emphasized (e.g. Cornelissen \& Thompson 1997, Hunt \& Cornelissen 1997 , Lavorel et al. 1997, Reich et al. 2003). The interaction between management and functional group (grasses vs. herbs) explained always less than $1 \%$ of the variation in general linear models with fertilization, cutting and functional group as factors (exception: $2.6 \%$ of $\mathrm{N}_{\text {area }}$ variance explained by a functional group $\mathrm{x}$ fertilization interaction, data not shown). The partly similar responses of grasses and herbs to environmental change indicates that the systematically distinct groups have evolved convergent strategies of responding to the specific growth conditions in this montane meadow.

Studies focusing on plant functional traits, and especially those that deal with grassland plant traits, have shown that species rankings based on leaf traits are fixed and independent from management or year indicating uniform trait responses of different species (Garnier et al. 1997, 2001, Pontes et al. 2007). In our study, cutting frequency and fertilization significantly altered trait-based species rankings but differed in their impact on the three types of species rankings investigated. Fertilization had a strong impact on $\mathrm{N}_{\text {area- }}$ based species rankings in 2009, but a minor impact on SLA-based rankings in 2009 and on $\mathrm{N}_{\text {mass }}$-based rankings in 2010. The cutting frequency led to stronger alterations of SLA- and

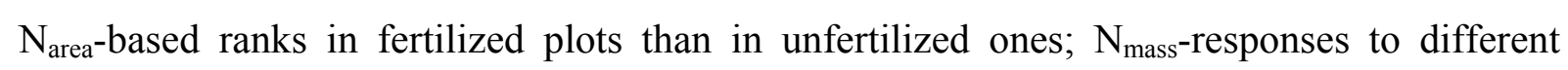
cutting frequencies were more uniform across the species and thus resulted in a less pronounced alteration of species rankings. These results show that, in the studied species, the amplitude of trait variation in response to management intensity changes is different between SLA, $\mathrm{N}_{\text {mass }}$ and $\mathrm{N}_{\text {area }}$. Significant rank alterations are the reflection of differences in species behavior. In 2009, for instance, SLA-based species rankings were strongly influenced by a 
specific response of D. glomerata to cutting and a lacking fertilizer response of this species, but not of the other species. Such a response seems to be characteristic for D. glomerata (Pontes et al. 2007) and is assumed to promote its ability for the rapid regrowth of new leaves after defoliation. The observed alterations in $\mathrm{N}_{\text {mass }}$-based rankings in 2010 can partly be attributed to a comparatively weak response of $F$. rubra to fertilization, a species known to be an inferior competitor for nitrogen (Klapp \& Opitz v. Boberveld 2006). Finally, the strong alteration of the $\mathrm{N}_{\text {area}}$-based rankings caused by fertilizer application in 2009 is attributable to the tight inter-relationship between $\mathrm{N}_{\text {area }}$ on the one side and SLA and $\mathrm{N}_{\text {mass }}$ on the other. Since, in most species, both SLA and $\mathrm{N}_{\text {mass }}$ increased upon fertilization, the change in $\mathrm{N}_{\text {area }}$ depended on whether the SLA or the $\mathrm{N}_{\text {mass }}$ increase was greater which varied between the species.

Our results clearly contradict the results of Pontes et al. 2007, who also analyzed the effects of altered $\mathrm{N}$-fertilization and cutting frequencies on leaf traits, trait relationships and species rankings over two years and reported constant species rankings. We see three possible reasons for the contrasting results of the two studies. First, the results of the two studies differ strongly in the importance of interspecific trait variability. The among-species trait variation was rather small in our study $\left(40,19\right.$ and $26 \%$ of the variance in SLA, $N_{\text {mass }}$ and $\mathrm{N}_{\text {area }}$ explained by species identity) and, consequently, small absolute changes in a trait can result in altered species rankings. In contrast, Pontes et al. (2007) found 91 and 44\% of the variance in SLA and $\mathrm{N}_{\text {mass }}$ explained by species identity, which may well have caused the consistency of species rankings in this study. Further, all eight species of our study originated from the same habitat and were similar with respect to their light and nutrient requirements according to the Ellenberg Indicator Values, a fact that has been shown to cause trait convergence (de Bello et al. 2009).

Second, the fertilizer input in our study caused a stronger alteration of leaf traits than it did in the study of Pontes et al. (2007) (8 vs. 1.5\% of SLA variance explained by fertilization) which may result from the different amounts of $\mathrm{N}$ input that the grassland received in the two studies (the local atmospheric $\mathrm{N}$ deposition and nitrogen fixation by legumes and $180 \mathrm{~kg} \mathrm{~N} \mathrm{ha}^{-1} \mathrm{yr}^{-1}$ fertilizer in our study vs. 120 and $360 \mathrm{~kg} \mathrm{~N} \mathrm{ha}^{-1} \mathrm{yr}^{-1}$ fertilization in the study of Pontes et al. 2007).

A third reason for the discrepancy between the two studies might be that our study, in contrast to that of Pontes et al. (2007), was conducted in a permanent grassland which has been shaped by long-term competitive interactions; they have the potential to severely alter plant performance under different environmental conditions (Wilson \& Tilman 1993). 
Although our results should be verified by additional studies at other temperate grassland sites, we conclude that the trait responses to management are not as uniform in temperate grasslands as were reported by earlier studies. Furthermore, because of interactions between the impact of different cutting frequencies and fertilization regimes on the investigated traits, we are unable to give a recommendation concerning the preferential use of one of the three investigated traits to predict species responses to land-use intensification.

\subsubsection{Alterations of leaf trait relationships and trait variability caused by} management

Relationships between leaf traits have been analyzed in different environments and on different spatial scales. Screening studies have shown that specific leaf area is closely related to $\mathrm{N}_{\text {mass }}$ (leaf $\mathrm{N}$ concentration) if species from different sites (Cunningham et al. 1999, He et al. 2006), different floras (Reich et al. 1997, Wright et al. 2004) or of different life forms are compared (Garnier et al. 2001, Wright et al. 2005b, but see Garnier et al. 1997). Hence, we hypothesized that relationships between leaf traits within a given plant community would also be constant and unaffected by the management regime. Surprisingly, the strength of the relationship between SLA and $\mathrm{N}_{\text {mass }}$ was strongly dependent on the fertilizer input at our site. Fertilization led to a decrease in between-species variation of $\mathrm{N}_{\text {mass }}$ values and thereby eliminated significant positive SLA- $\mathrm{N}_{\text {mass }}$ relationships, which occurred in unfertilized plots. Moreover, as a mathematical consequence, the SLA- $\mathrm{N}_{\text {area }}$ relationship was stronger in fertilized plots than in unfertilized ones. We found a stronger increase of mass-specific foliar $\mathrm{N}$ upon fertilization if the $\mathrm{N}_{\text {mass }}$ values of the species in the corresponding unfertilized treatment were low than in N-richer plants (significant negative relation between the observed increase in $\mathrm{N}_{\text {mass }}$ upon fertilization and the $\mathrm{N}_{\text {mass }}$ value of the unfertilized treatment, $\mathrm{R}^{2}=0.28$, $P<0.01$ ); this dependence of $\mathrm{N}$ accumulation on the plant's initial foliar $\mathrm{N}$ status reduced the among-species variation in $\mathrm{N}_{\text {mass }}$. One possible explanation for this unexpected finding might be altered competitive interaction patterns when $\mathrm{N}$ availability is improved. It appears that the asymmetry of competition for $\mathrm{N}$ has decreased upon $\mathrm{N}$ addition in our experiment and that initially $\mathrm{N}$-poor plants were capable of accumulating more additional $\mathrm{N}$ than initially N-rich plants. Experiments on the intensity of interspecific competition at varied $\mathrm{N}$ availability and $\mathrm{N}$ uptake studies with ${ }^{15} \mathrm{~N}$ would be needed to understand the underlying mechanisms of this response. 
Our results on management effects on trait variability allow only to draw conclusions about the short-term effect of different land-use regimes and intensities. More far-reaching conclusions require additional studies on the long-term response of the meadow community covering several years when changes in competitive interactions and thus in species composition will manifest.

\subsubsection{Conclusion}

Understanding the relationships between leaf traits and trait responses to changing environmental conditions has been the focus of much research over the last decades because functional traits are known to determine ecosystem properties (Grime 1997, Díaz et al. 2004, Westoby \& Wright 2006). Responses of functional leaf traits to land-use intensification showed little generality in our study when species adapted to the same environment were considered in a semi-natural grassland, indicating that observations made on the species level do not necessarily mirror trait syndromes on the ecosystem level. We have to reject our hypothesis that trait relationships remain invariant under land-use intensification, which is mainly a consequence of a decrease in $\mathrm{N}_{\text {mass }}$ variation among the species upon fertilization. This result casts doubt on the generality of leaf-trait relationships under different land-use intensities. Thus, we conclude that findings on trait variation and trait inter-relationships gained from data sets containing species with largely different ecologies and from different habitats and results obtained from monocultures can only carefully be extrapolated to the community level.

\subsection{References}

Abrams, M.D., Kubiske, M.E. \& Mostoller, S.A. (1994) Relating wet and dry year ecophysiology to leaf structure in contrasting temperate tree species. Ecology 75, 123-133.

Albert, C.H., Thuiller, W., Yoccoz, N.G., Douzet, R., Aubert, S. \& Lavorel, S. (2010) A multi-trait approach reveals the structure and the relative importance of intra- vs. interspecific variability in plant traits. Functional Ecology 24, 1192-1201.

Anderson, V.J. \& Briske, D.D. (1995) Herbivore-induced species replacement in grasslands - Is it driven by herbivory tolerance or avoidance. Ecological Applications 5, 1014-1024.

Bakker, E.S., Knops, J.M.H., Milchunas, D.G., Ritchie, M.E. \& Olff, H. (2009) Cross-site comparison of herbivore impact on nitrogen availability in grasslands: the role of plant nitrogen concentration. Oikos 118, 1613-1622. 
Berg, G. \& McClaugherty, C. (2003) Plant litter. decomposition, humus formation, carbon sequestration. Springer, Berlin.

Burke, I.C., Lauenroth, W.K., Vinton, M.A., Hook, P.B., Kelly, R.H., Epstein, H.E., Aguiar, M.R., Robles, M.D., Aguilera, M.O., Murphy, K.L. \& Gill, R.A. (1998) Plant-soil interactions in temperate grasslands. Biogeochemistry 42, 121-143.

Chapin, F.S., Zavaleta, E.S., Eviner, V.T., Naylor, R.L., Vitousek, P.M., Reynolds, H.L., Hooper, D.U., Lavorel, S., Sala, O.E., Hobbie, S.E., Mack, M.C. \& Díaz, S. (2000) Consequences of changing biodiversity. Nature 405, 234-242.

Cornelissen, J.H.C. \& Thompson, K. (1997) Functional leaf attributes predict litter decomposition rate in herbaceous plants. New Phytologist 135, 109-114.

Cunningham, S.A., Summerhayes, B. \& Westoby, M. (1999) Evolutionary divergences in leaf structure and chemistry, comparing rainfall and soil nutrient gradients. Ecological Monographs 69, 569-588.

De Bello, F., Thuiller, W., Lepš, J., Choler, P., Clément, J.C., Macek, P., Sebastià, M.T. \& Lavorel, S. (2009) Partitioning of functional diversity reveals the scale and extent of trait convergence and divergence. Journal of Vegetation Science 20, 475-486.

Dierschke, H. \& Briemle, G. (2002) Kulturgrasland. Ulmer Verlag, Stuttgart.

Díaz, S., Acosta, A. \& Cabido, M. (1992) Morphological analysis of herbaceous communities under different grazing regimes. Journal of Vegetation Science 3, 689-696.

Díaz, S., Hodgson, J.G., Thompson, K., Cabido, M., Cornelissen, J.H.C., Jalili, A., Montserrat-Marti, G., Grime, J.P., Zarrinkamar, F., Asri, Y., Band, S.R., Basconcelo, S., Castro-Diez, P., Funes, G., Hamzehee, B., Khoshnevi, M., Perez-Harguindeguy, N., Perez-Rontome, M.C., Shirvany, F.A., Vendramini, F., Yazdani, S., Abbas-Azimi, R., Bogaard, A., Boustani, S., Charles, M., Dehghan, M., de Torres-Espuny, L., Falczuk, V., Guerrero-Campo, J., Hynd, A., Jones, G., Kowsary, E., Kazemi-Saeed, F., Maestro-Martinez, M., Romo-DÍez, A., Shaw, S., Siavash, B., Villar-Salvador, P. \& Zak, M.R. (2004) The plant traits that drive ecosystems: Evidence from three continents. Journal of Vegetation Science 15, 295-304.

Dubey, P., Raghubanshi, A.S. \& Singh, J.S. (2011) Intra-seasonal variation and relationship among leaf traits of different forest herbs in a dry tropical environment. Current Science 100, 69-76.

Ellenberg, H. (1992) Zeigerwerte von Pflanzen in Mitteleuropa. Goltze, Göttingen.

Ellenberg, H. \& Leuschner, Ch. (2010) Vegetation Mitteleuropas mit den Alpen. (6 ${ }^{\text {th }}$ ed.) Ulmer Verlag, Stuttgart.

Fonseca, C.R., Overton, J.M., Collins, B. \& Westoby, M. (2000) Shifts in trait-combinations along rainfall and phosphorus gradients. Journal of Ecology 88, 964-977.

From, T., Petersen, U., and Isselstein, J. Productivity and forage quality of a phytodiverse semi-natural grassland under various management regimes. Available from Nature Precedings http://dx.doi.org/10.1038/npre.2011.6622.1

Garnier, E., Cordonnier, P., Guillerm, J.L. \& Sonie, L. (1997) Specific leaf area and leaf nitrogen concentration in annual and perennial grass species growing in Mediterranean old-fields. Oecologia 111, 490-498. 
Garnier, E., Laurent, G., Bellmann, A., Debain, S., Berthelier, P., Ducout, B., Roumet, C. \& Navas, M.L. (2001) Consistency of species ranking based on functional leaf traits. New Phytologist 152, 69-83.

Grime, J.P., Hodgson, J.G. \& Hunt, R. (1988) Comparative plant ecology: a functional approach to common British species. Unwin Hyman, London.

Grime, J.P. (1997) Biodiversity and ecosystem function: The debate deepens. Science 277, 1260-1261.

Grime, J.P. (2006) Trait convergence and trait divergence in herbaceous plant communities: Mechanisms and consequences. Journal of Vegetation Science 17, 255-260.

He, J.S., Wang, Z.H., Wang, X.P., Schmid, B., Zuo, W.Y., Zhou, M., Zheng, C.Y., Wang, M.F. \& Fang, J.Y. (2006) A test of the generality of leaf trait relationships on the Tibetan Plateau. New Phytologist 170, 835-848.

Hooper, D.U. (1998) The role of complementarity and competition in ecosystem responses to variation in plant diversity. Ecology 79, 704-719.

Hunt, R. \& Cornelissen, J.H.C. (1997) Components of relative growth rate and their interrelations in 59 temperate plant species. New Phytologist 135, 395-417.

Jacquemyn, H., Brys, R. \& Hermy, M. (2003) Short-term effects of different management regimes on the response of calcareous grassland vegetation to increased nitrogen. Biological Conservation 111, 137-147.

Jaramillo, V.J. \& Detling, J.K. (1988) Grazing history, defoliation, and competition - Effects on shortgrass production and nitrogen accumulation. Ecology 69, 1599-1608.

Klapp, E. \& Opitz v.Boberveld, W. (2006) Taschenbuch der Gräser. Ulmer Verlag, Stuttgart.

Klimek, S., Kemmermann, A.R.G., Hofmann, M. \& Isselstein, J. (2007) Plant species richness and composition in managed grasslands: The relative importance of field management and environmental factors. Biological Conservation 134, 559-570.

Klimek, S., Marini, L., Hofmann, M. \& Isselstein, J. (2008) Additive partitioning of plant diversity with respect to grassland management regime, fertilisation and abiotic factors. Basic and Applied Ecology 9, 626-634.

Krause, B., Culmsee, H., Wesche, K., Bergmeier, E. \& Leuschner, C. (2011) Habitat loss of floodplain meadows in north Germany since the 1950s. Biodiversity and Conservation 20, 2347-2364.

Lamont, B.B., Groom, P.K. \& Cowling, R.M. (2002) High leaf mass per area of related species assemblages may reflect low rainfall and carbon isotope discrimination rather than low phosphorus and nitrogen concentrations. Functional Ecology 16, 403-412.

Larsen, K.S., Andresen, L.C., Beier, C., Jonasson, S., Albert, K.R., Ambus, P., Arndal, M.F., Carter, M.S., Christensen, S., Holmstrup, M., Ibrom, A., Kongstad, J., van der Linden, L., Maraldo, K., Michelsen, A., Mikkelsen, T.N., Pilegaard, K., Priemé, A., Ro-Poulsen, H., Schmidt, I.K., Selsted, M.B. \& Stevnbak, K. (2011) Reduced N cycling in response to elevated $\mathrm{CO}_{2}$, warming, and drought in a Danish heathland: Synthesizing results of the CLIMAITE project after two years of treatments. Global Change Biology 17, 1884-1899.

Lavorel, S., McIntyre, S., Landsberg, J. \& Forbes, T.D.A. (1997) Plant functional classifications: from general groups to specific groups based on response to disturbance. Trends in Ecology \& Evolution 12, 474-478. 
Long, W.X., Zang, R.G., Schamp, B.S. \& Ding, Y. (2011) Within- and among-species variation in specific leaf area drive community assembly in a tropical cloud forest. Oecologia 167, 11031113 .

Loreau, M., Naeem, S., Inchausti, P., Bengtsson, J., Grime, J.P., Hector, A., Hooper, D.U., Huston, M.A., Raffaelli, D., Schmid, B., Tilman, D. \& Wardle, D.A. (2001) Biodiversity and ecosystem functioning: Current knowledge and future challenges. Science 294, 804-808.

Louault, F., Pillar, V.D., Aufrere, J., Garnier, E. \& Soussana, J.F. (2005) Plant traits and functional types in response to reduced disturbance in a semi-natural grassland. Journal of Vegetation Science 16, 151-160.

Maurer, K., Weyand, A., Fischer, M. \& Stöcklin, J. (2006) Old cultural traditions, in addition to land use and topography, are shaping plant diversity of grasslands in the Alps. Biological Conservation 130, 438-446.

Ordoñez, J.C., van Bodegom, P.M., Witte, J.P.M., Wright, I.J., Reich, P.B. \& Aerts, R. (2009) A global study of relationships between leaf traits, climate and soil measures of nutrient fertility. Global Ecology and Biogeography 18, 137-149.

Petersen, U., Wrage, N., Köhler, L., Leuschner, C. \& Isselstein, J. (2011) Manipulating the species composition of permanent grasslands - A new approach to biodiversity experiments. Basic and Applied Ecology in press, doi:10.1016/j.baae.2011.10.003.

Pontes, L.D.S., Soussana, J.F., Louault, F., Andueza, D. \& Carrère, P. (2007) Leaf traits affect the above-ground productivity and quality of pasture grasses. Functional Ecology 21, 844-853.

Poorter, H. \& Evans, J.R. (1998) Photosynthetic nitrogen-use efficiency of species that differ inherently in specific leaf area. Oecologia 116, 26-37.

Poorter, H. \& De Jong, R. (1999) A comparison of specific leaf area, chemical composition and leaf construction costs of field plants from 15 habitats differing in productivity. New Phytologist 143, 163-176.

Poorter, H., Niinemets, Ü., Poorter, L., Wright, I.J. \& Villar, R. (2009) Causes and consequences of variation in leaf mass per area (LMA): a meta-analysis. New Phytologist 182, 565-588.

Quétier, F., Thébault, A. \& Lavorel, S. (2007) Plant traits in a state and transition framework as markers of ecosystem response to land-use change. Ecological Monographs 77, 33-52.

Reich, P.B., Walters, M.B. \& Ellsworth, D.S. (1997) From tropics to tundra: Global convergence in plant functioning. Proceedings of the National Academy of Sciences of the United States of America 94, 13730-13734.

Reich, P.B., Ellsworth, D.S. \& Walters, M.B. (1998) Leaf structure (specific leaf area) modulates photosynthesis-nitrogen relations: evidence from within and across species and functional groups. Functional Ecology 12, 948-958.

Reich, P.B., Buschena, C., Tjoelker, M.G., Wrage, K., Knops, J., Tilman, D. \& Machado, J.L. (2003) Variation in growth rate and ecophysiology among 34 grassland and savanna species under contrasting N supply: a test of functional group differences. New Phytologist 157, 617-631.

Ryser, P. \& Eek, L. (2000) Consequences of phenotypic plasticity vs. interspecific differences in leaf and root traits for acquisition of aboveground and belowground resources. American Journal of Botany 87, 402-411. 
Sala, O.E., Chapin, F.S., Armesto, J.J., Berlow, E., Bloomfield, J., Dirzo, R., Huber-Sanwald, E., Huenneke, L.F., Jackson, R.B., Kinzig, A., Leemans, R., Lodge, D.M., Mooney, H.A., Oesterheld, M., Poff, N.L., Sykes, M.T., Walker, B.H., Walker, M. \& Wall, D.H. (2000) Global biodiversity scenarios for the year 2100. Science 287, 1770-1774.

Schulze, E.D., Kelliher, F.M., Körner, C., Lloyd, J. \& Leuning, R. (1994) Relationships among maximum stomatal conductance, ecosystem surface conductance, carbon assimilation rate, and plant nitrogen nutrition - A global ecology scaling exercise. Annual Review of Ecology and Systematics 25, 629-660.

Tasser, E. \& Tappeiner, U. (2002) Impact of land use changes on mountain vegetation. Applied Vegetation Science 5, 173-184.

Thorne, M.A. \& Frank, D.A. (2009) The effects of clipping and soil moisture on leaf and root morphology and root respiration in two temperate and two tropical grasses. Plant Ecology 200, 205-215.

Vitousek, P.M., Mooney, H.A., Lubchenco, J. \& Melillo, J.M. (1997) Human domination of earth's ecosystems. Science $277,494-499$.

Westoby, M. \& Wright, I.J. (2006) Land-plant ecology on the basis of functional traits. Trends in Ecology \& Evolution 21, 261-268.

Wilson, P.J., Thompson, K. \& Hodgson, J.G. (1999) Specific leaf area and leaf dry matter content as alternative predictors of plant strategies. New Phytologist 143, 155-162.

Wilson, S.D. \& Shay, J.M. (1990) Competition, fire, and nutrients in a mixed-grass prairie. Ecology 71, 1959-1967.

Wilson, S.D. \& Tilman, D. (1993) Plant competition and resource availability in response to disturbance and fertilization. Ecology 74, 599-611.

Wright, I.J., Reich, P.B., Westoby, M., Ackerly, D.D., Baruch, Z., Bongers, F., Cavender-Bares, J., Chapin, T., Cornelissen, J.H.C., Diemer, M., Flexas, J., Garnier, E., Groom, P.K., Gulias, J., Hikosaka, K., Lamont, B.B., Lee, T., Lee, W., Lusk, C., Midgley, J.J., Navas, M.L., Niinemets, U., Oleksyn, J., Osada, N., Poorter, H., Poot, P., Prior, L., Pyankov, V.I., Roumet, C., Thomas, S.C., Tjoelker, M.G., Veneklaas, E.J. \& Villar, R. (2004) The worldwide leaf economics spectrum. Nature 428, 821-827.

Wright, I.J., Reich, P.B., Cornelissen, J.H.C., Falster, D.S., Garnier, E., Hikosaka, K., Lamont, B.B., Lee, W., Oleksyn, J., Osada, N., Poorter, H., Villar, R., Warton, D.I. \& Westoby, M. (2005) Assessing the generality of global leaf trait relationships. New Phytologist 166, 485-496.

Wright, I.J., Reich, P.B., Cornelissen, J.H.C., Falster, D.S., Groom, P.K., Hikosaka, K., Lee, W., Lusk, C.H., Niinemets, Ü., Oleksyn, J., Osada, N., Poorter, H., Warton, D.I. \& Westoby, M. (2005) Modulation of leaf economic traits and trait relationships by climate. Global Ecology and Biogeography 14, 411-421. 
Table 5A.1: Management procedures conducted at the experimental site, date of leaf sampling and agricultural yield in the study years 2009 and 2010.

\begin{tabular}{|c|c|c|c|c|c|c|c|c|}
\hline 2009 & $15 / 04$ & $14 / 05$ & $28 / 05$ & $04 / 06$ & $06-16 / 06$ & 09/07 & & $30 / 09$ \\
\hline 2010 & $21 / 04$ & $26 / 05$ & 01/06 & $01 / 06$ & & $20 / 07$ & $17-23 / 08$ & 29/09 \\
\hline ttment & $\begin{array}{l}90 \\
\mathrm{~kg} \mathrm{~N} \mathrm{ha}^{-1}\end{array}$ & Cutting & $\begin{array}{l}90 \\
\operatorname{kg~N~ha}^{-1}\end{array}$ & $\begin{array}{l}30 \mathrm{~kg} \mathrm{P} \mathrm{ha}^{-1} \\
107 \mathrm{~kg} \mathrm{~K} \mathrm{ha}^{-1}\end{array}$ & $\begin{array}{c}\text { Leaf } \\
\text { sampling }\end{array}$ & Cutting & $\begin{array}{c}\text { Leaf } \\
\text { sampling }\end{array}$ & Cutting \\
\hline $\mathrm{K}-\mathrm{C} 1$ & & & & & $\mathrm{X}$ & $\mathrm{X}$ & $\mathrm{x}$ & \\
\hline $\mathrm{K}+\mathrm{C} 1$ & $\mathrm{x}$ & & $\mathrm{x}$ & $\mathrm{x}$ & $\mathrm{x}$ & $\mathrm{x}$ & $\mathrm{x}$ & \\
\hline $\mathrm{K}-\mathrm{C} 3$ & & $\mathrm{X}$ & & & $\mathrm{x}$ & $\mathrm{X}$ & $\mathrm{x}$ & $\mathrm{x}$ \\
\hline $\mathrm{x}+\mathrm{C} 3$ & $\mathrm{x}$ & $\mathrm{X}$ & $\mathrm{X}$ & $\mathrm{X}$ & $\mathrm{X}$ & $\mathrm{X}$ & $\mathrm{x}$ & $\mathrm{X}$ \\
\hline
\end{tabular}

Table 5A.2: Global radiation, precipitation and mean air temperature (mean 1960-1990, 2009 and 2010) at Silberborn, Solling Mountains (DWD, 1960-1990) and at the GrassMan site at $2 \mathrm{~m}$ height (2009/2010).

\begin{tabular}{lcccccccc}
\hline & Apr & May & Jun & Jul & Aug & Sep & Apr - Sep & Annual \\
\hline Mean 1960-1990 & & & & & & & & \\
Precipitation $(\mathrm{mm})$ & 77 & 84 & 108 & 97 & 85 & 78 & 529 & 1031 \\
Temperature $\left({ }^{\circ} \mathrm{C}\right)$ & 6 & 11 & 14 & 15 & 15 & 12 & 12 & 7 \\
2009 & & & & & & & & \\
Global radiation $\left(\mathrm{MJ} \mathrm{m}^{-2}\right)$ & 425 & 493 & 444 & 488 & 456 & 266 & 2572 & 3146 \\
Precipitation $(\mathrm{mm})$ & 22 & 70 & 53 & 113 & 49 & 81 & 388 & 1001 \\
Temperature $\left({ }^{\circ} \mathrm{C}\right)$ & 12 & 12 & 13 & 17 & 18 & 14 & 14 & 8 \\
2010 & & & & & & & & \\
Global radiation $\left(\mathrm{MJ} \mathrm{m}^{-2}\right)$ & 382 & 334 & 556 & 533 & 298 & 216 & 2319 & 2882 \\
Precipitation $(\mathrm{mm})$ & 15 & 113 & 26 & 47 & 182 & 102 & 485 & 1110 \\
Temperature $\left({ }^{\circ} \mathrm{C}\right)$ & 9 & 10 & 17 & 21 & 17 & 13 & 15 & 8 \\
\hline
\end{tabular}




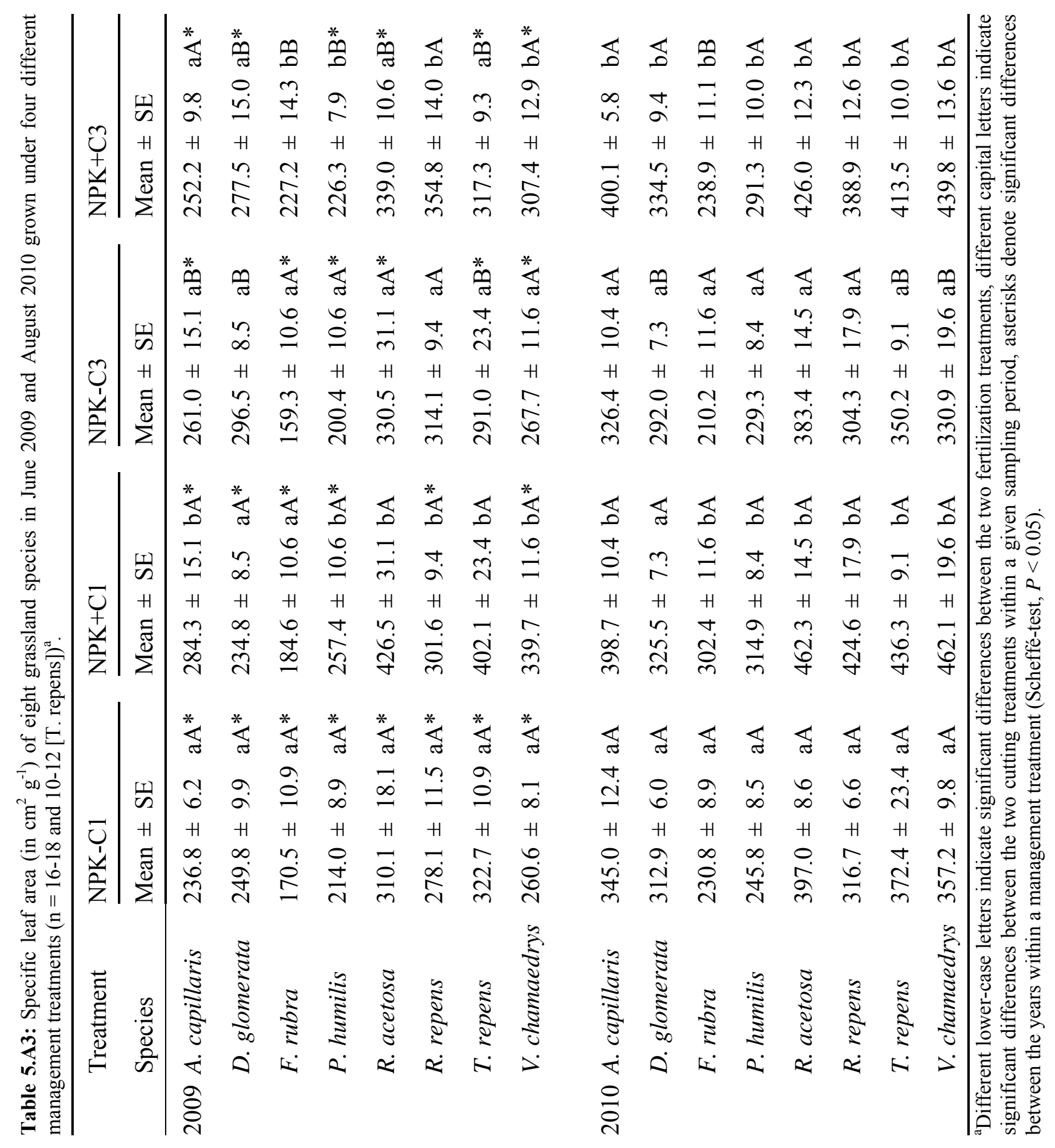




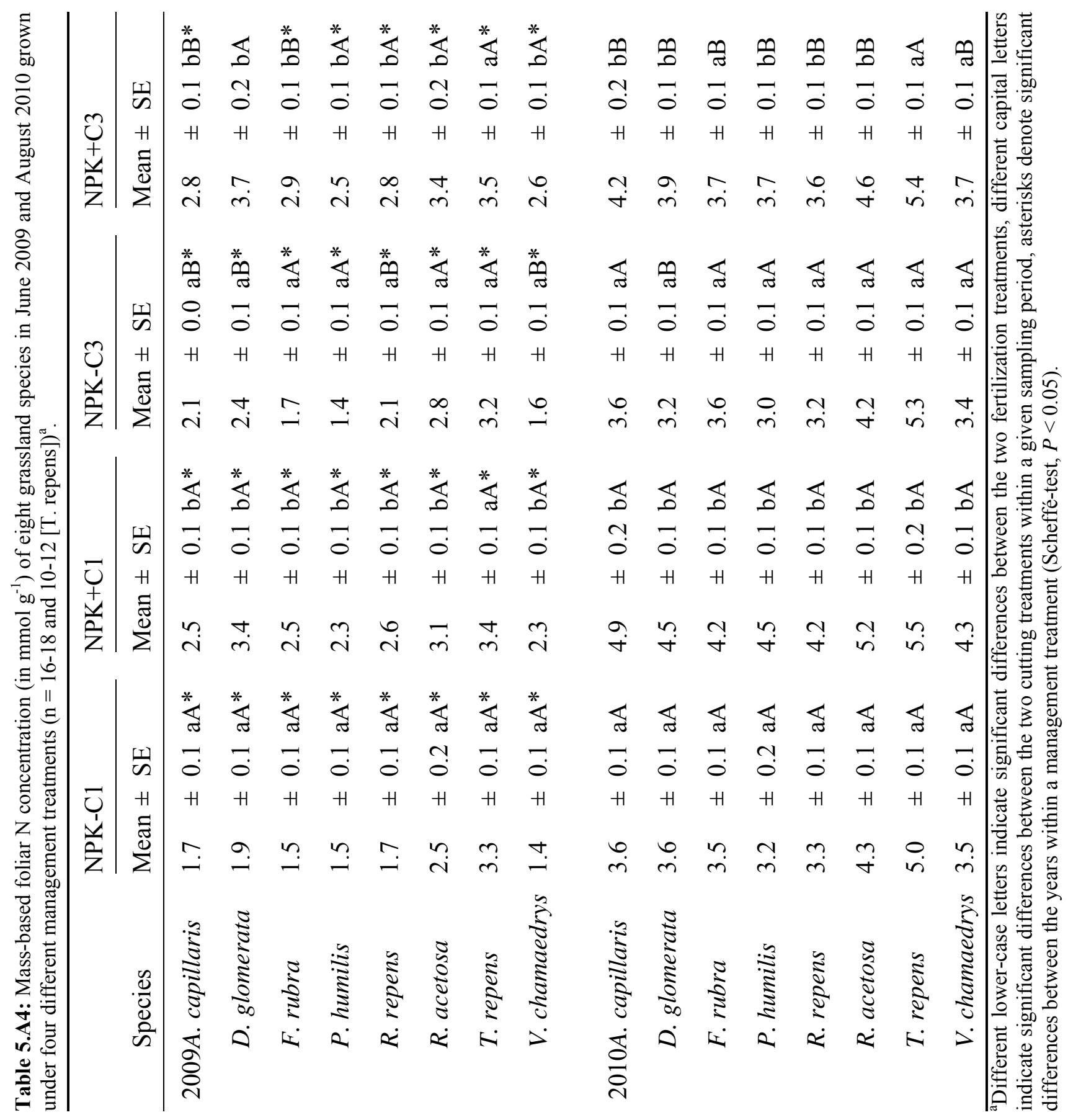




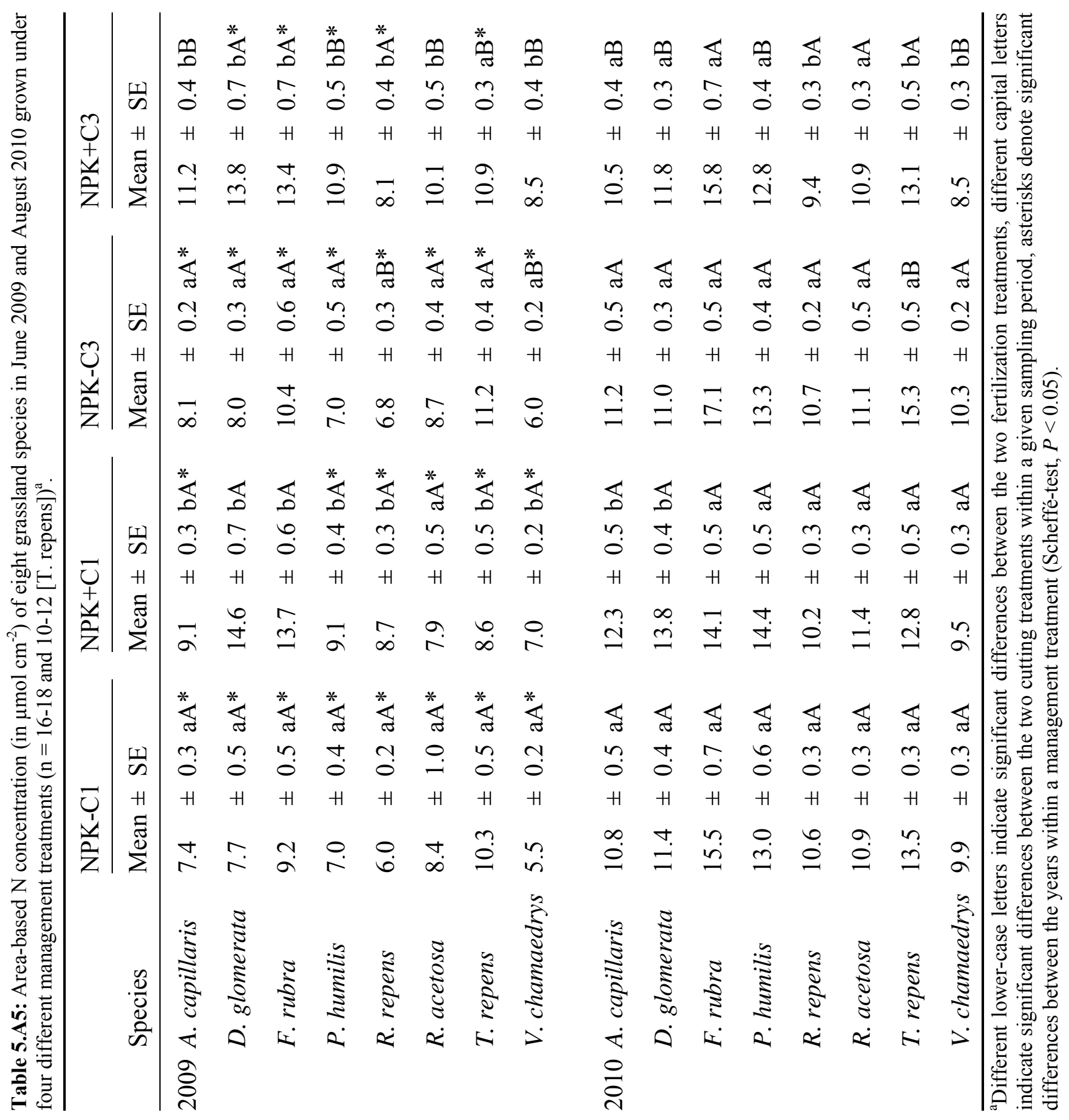


Table 5A.6: Biomass yields at the GrassMan site in the two study years (in Mg dry mass ha $\left.{ }^{-1}\right)$.

\begin{tabular}{|c|c|c|c|c|c|c|c|c|}
\hline Year & 2009 & & & & 2010 & & & \\
\hline Treatment & Mean & \pm & $\mathrm{SE}$ & & Mean & \pm & $\mathrm{SE}$ & \\
\hline NPK- C1 & 5.71 & \pm & 0.16 & $\mathrm{a}$ & 3.93 & \pm & 0.25 & $\mathrm{a}$ \\
\hline $\mathrm{NPK}+\mathrm{C} 1$ & 8.00 & \pm & 0.35 & b & 4.36 & \pm & 0.24 & $\mathrm{a}$ \\
\hline NPK- C3 & 5.88 & \pm & 0.30 & $\mathrm{a}$ & 4.82 & \pm & 0.31 & $\mathrm{a}$ \\
\hline $\mathrm{NPK}+\mathrm{C} 3$ & 11.44 & \pm & 0.32 & $\mathrm{c}$ & 9.33 & \pm & 0.35 & b \\
\hline
\end{tabular}

Data provided by U. Petersen and T. From. Different letters indicate significant differences between treatments within a given year (Scheffé-test, $P<0.05, \mathrm{n}=18$ ). 

CHAPTER 6

Synthesis 


\subsection{Biodiversity, management and ecosystem structure and functions}

In chapter 1, we formulated a number of study aims concerning ecosystem structure and functioning of temperate grasslands either in relation to management, plant species richness, or functional group abundance that were discussed in the previous four chapters. This chapter aims at integrating the results obtained from our four studies and to draw more general conclusions about the importance of plant diversity and management for the productivity and functioning of grassland ecosystems.

We analyzed the structure of meadows (GrassMan) and pastures (BIOMIX) with a particular focus on above- and belowground biomass, nitrogen partitioning as well as leaf functional traits. The ecosystem functions investigated were grassland evapotranspiration and deep seepage, biomass production and forage supply for livestock grazing. The management at our two study sites differed in either the type of livestock grazing (cattle, sheep or cograzing of a mixture of both), or in cutting frequencies (one vs. three cuttings per season) in unfertilized and NPK-fertilized meadow plots. Species richness as well as plant functional group abundances were manipulated by specific herbicide application at both sites, i.e. by reducing the abundance of certain plant functional groups.

\subsubsection{The importance of management for ecosystem structure and functioning}

Livestock grazing led to a $60-80 \%$ reduction of mid-summer aboveground standing biomass and a $25-75 \%$ reduction of aboveground nitrogen compared to the ungrazed control at the BIOMIX site. The amount of biomass and nitrogen removed by grazing depended on the type of livestock grazing. Furthermore, livestock grazing decreased the $\mathrm{C} / \mathrm{N}$ ratio of the residual biomass and thus has the strong potential to alter foliage quality. Belowground biomass and nitrogen pools were remarkably unaffected not only by the type of livestock grazing, but also by grazing in general. A similar pattern was found at the GrassMan site, where the aboveground biomass as well as biomass production strongly depended on the management regime, but alterations in belowground standing biomass and fine root distribution were of smaller magnitude and only partially significant. In detail, NPKfertilization had a strong, and the increase of cutting frequency from one to three cuttings per season, a minor positive effect on aboveground biomass production. The above- as well as belowground standing biomasses at the last cutting event were slightly decreased under higher 
cutting frequency. In summary, it appears that the belowground system of meadows and pastures seems to be more robust against alterations in the management regime than the aboveground system. This discrepancy between above- and belowground responses to management leads to large changes of root:shoot biomass ratio in temperate pastures and meadows.

These structural changes had a significant effect on evapotranspiration and groundwater recharge, which both came out to be strongly dependent on aboveground standing biomass. Fertilization with $180 \mathrm{~kg} \mathrm{~N} \mathrm{ha}^{-1}$ did not only lead to an increase in evapotranspiration and a decrease in ground water recharge during the growing season by $50 \%$, but did also increase the water use efficiency at the stand and leaf level at the GrassMan site. Further, investigations of the response of leaf morphology and nitrogen status confirmed that fertilization has a strong impact not only on plant functional traits, but also on trait based species rankings and functional trait variation and relationships between traits.

\subsubsection{Minor importance of species richness and interactions with management}

As summarized in chapter 1, plant species or functional group richness is assumed to positively influence the productivity and functioning of ecosystems. Studies on artificial grassland ecosystems verified these positive biodiversity effects, while the evidence for positive biodiversity-productivity effects is not convincing from studies in mature grassland communities so far.

Neither functional group richness nor species richness itself influenced the aboveground standing biomass at the studied sites. At the GrassMan site, the aboveground biomass production and the root area index were significantly negatively related to the small-scale species richness, thereby contradicting results from artificial grassland assemblages. Positive biodiversity effects are assumed to be caused by complementarity in resource use or niche differentiation, for which we can provide no evidence from our study. Similar to several other studies, our results support recently forwarded hypotheses about the stability of mature ecosystems to non-random species losses, as summarized in chapter 1 . The effect of plant diversity was only of negligible importance compared to alterations of productivity caused by fertilization. Finally, the water balance of this grassland, although closely related to biomass production, was unaffected by sward diversity. 
For all other parameters, biodiversity effects, if statistically significant, depended on the management regime. At the BIOMIX site, the amount of aboveground biomass removed by livestock was not affected by the abundance of different functional groups in general, but livestock type effects depended on functional group diversity. However, this was most likely not an effect of functional group richness or evenness, but of functional group identity, since it is known, that sheep and cattle strongly differ in their preferences for herb and grass biomass. Hence, we may conclude, that including the management regime in interpretations of the relationship between species richness and biomass or ecosystem functions is critical for drawing realistic conclusions.

\subsection{Concluding remarks}

We conclude that although functional biodiversity research in artificial grassland assemblages may increase our understanding of species interactions, it does not benefit a prediction of the functioning of semi-natural grassland ecosystems under increased management intensity that is expected in the future.

Our study clearly shows that management is the most important factor determining structure, productivity and ecosystem processes in temperate mature grassland ecosystems while species richness is only a subordinate factor. The effects of management on grassland structure may become even stronger than observed in our studies, where different management only lasted for two growing seasons, because in the long term, species composition may shift. Such alterations are most likely to occur as a response to alterations in resource availability and disturbance intensity.

Thus, we conclude, that understanding the effects of management on grassland ecosystem structure is of paramount importance for predicting future changes in ecosystem functioning under land-use change. 


\title{
CHAPTER 7
}

\author{
Summary
}




\subsection{Summary}

Agricultural intensification has transformed most grasslands of Central and Western Europe from extensive to highly intensive management during the last 50 years, resulting in a strong increase in biomass production and large reductions of plant species diversity. We investigated the impact of different management intensities and plant diversity on the structure and functioning of temperate pastures and meadows.

The study took place within the framework of two projects in the Solling Mountains, Central Germany in the years 2008 to 2010: The BIOMIX project aims at disentangling the effects of plant functional group abundances and different types of livestock on species composition, grassland yields, plant nitrogen status and biomass allocation. The objective of the GrassMan project is to investigate the effects of plant species richness and land-use intensification on the above mentioned parameters and the water balance of meadows.

At the BIOMIX site, we investigated the effects of different types of livestock in pastures with different abundances of herbs and grasses on above- and belowground biomass and nitrogen allocation. Pastures were grazed by cattle, sheep, or a mixture of both for two years before we conducted vegetation analyses, biomass sampling and biomass $\mathrm{N}$ analyses. Aboveground biomass was reduced up to $80 \%$ by grazing while belowground biomass was not altered. Cattle reduced aboveground biomass to a larger extent than sheep in diverse pastures while sheep grazing tended to do so in grass-dominated pastures. The aboveground $\mathrm{N}$ pool was less reduced than biomass, because grazing reduced the $\mathrm{C} / \mathrm{N}$ ratio of aboveground biomass relative to the ungrazed control.

The GrassMan project is conducted in a matrix of meadow plots at an old grown permanent grassland site. Plots differ in fertilization (no vs. NPK-fertilization) and cutting frequency (one vs. three cuttings per season) and a gradient of species richness was created by the application of herbicides either against dicotyledonous or monocotyledonous species.

One of our approaches at the GrassMan site aims at analyzing the effects of species richness under altered cutting frequencies with and without fertilization on above- and belowground biomass and biomass production. While fertilization had a strong positive effect on standing aboveground biomass and aboveground biomass production and increased cutting frequency a minor positive effect on aboveground biomass production, the effect of plant species richness on aboveground biomass was insignificant and aboveground biomass 
production was negatively related to species richness. Root biomass and distribution patterns gave no indication of belowground complementary resource use at this site.

Another study, also conducted at the GrassMan site, focused on the effects of different land-use intensities on the water balance of temperate meadows. With small weighable lysimeters, we measured evapotranspiration and infiltration rates in response to different management intensities during the growing season 2009. Aboveground biomass production, belowground biomass, root length density, plant diversity, water use efficiency, and climatic factors were also measured. Fertilization increased aboveground biomass production by $50-$ $70 \%$ and stand evapotranspiration by $10-15 \%$, while infiltration and groundwater recharge decreased by about $50 \%$. Consequently, fertilization increased the water use efficiency of the grassland plants by $20-30 \%$, while increasing the mowing frequency from one to three had no significant effect. We found close relations between aboveground biomass production and evapotranspiration or infiltration and conclude that grassland management intensification influences the water balance primarily through fertilization effects on productivity.

The last focus was on plant functional trait responses to climatic conditions and different land-use at the GrassMan site in 2009 and 2010. We measured the specific leaf area (SLA) of eight grassland species and related the values to mass- and area-based nitrogen concentrations of the leaves $\left(\mathrm{N}_{\text {mass }}, \mathrm{N}_{\text {area }}\right.$, respectively). It could be shown that NPK-fertilization led to generally higher SLA, $\mathrm{N}_{\text {mass }}$ and $\mathrm{N}_{\text {area }}$ values, while the effect of altered cutting frequencies on leaf traits was more species-specific. A dry period followed by a period of high precipitation led to higher values of these traits in 2010 compared to 2009. Differences in species responses to management altered the trait-based species rankings and the SLA-N $\mathrm{N}_{\text {mass }}$ and SLA-N $\mathrm{N}_{\text {area }}$ relationships. These results indicate that plant functional traits are not as consistent between management and years as suggested by earlier studies.

\subsection{Zusammenfassung}

In den vergangenen 50 Jahren wurden im Zuge einer landwirtschaftlichen Intensivierung viele Grünlandflächen Mittel- und Westeuropas von extensiv zu intensiv genutztem Grasland umgewandelt. Dies führte $\mathrm{zu}$ einer stark gesteigerten Biomasseproduktion, einhergehend mit einer starken Verringerung der pflanzlichen Artenvielfalt. Aus diesem Grund haben wir den Einfluss verschiedener 
Landnutzungsintensitäten und der pflanzlichen Diversität auf die Struktur und Ökosystemfunktionen von temperaten Wiesen und Weiden untersucht.

Diese Studie wurde im Kontext zweier Großprojekte in den Jahren 2008 bis 2010 im Solling in Mitteldeutschland durchgeführt: Das BIOMIX Projekt hat zum Ziel, den Einfluss der Häufigkeit unterschiedlicher funktioneller Pflanzengruppen in der Grasnarbe und verschiedener Weidetiere auf Produktion, Artzusammensetzung, den pflanzlichen Stickstoffgehalt und Biomasseallokation von Grünland zu analysieren. Im GrassMan Projekt wird der Einfluss der Bewirtschaftungsintensität von Mähwiesen auf den Wasserhaushalt, sowie auf die oben genannten Parameter entlang eines Gradienten in der pflanzlichen Artenvielfalt untersucht.

Wir haben auf der BIOMIX Fläche im Jahr 2008 den Effekt von verschiedenen Weidetierarten auf die ober- und unterirdische Biomasse und die Stickstoffallokation in Abhängigkeit der Häufigkeit von Gräsern, Krautigen und Leguminosen in der Grasnarbe untersucht. Unterschiedliche Beweidung - entweder mit Rindern, Schafen oder einer Mischung aus beiden - erfolgte für zwei Jahre vor der Durchführung von Vegetationsaufnahmen, ober- und unterirdischen Biomasseerhebungen und Stickstoffanalysen. Während die oberirdische Biomasse durch Beweidung um bis zu $80 \%$ reduziert wurde, blieb die unterirdische Biomasse im Vergleich mit unbeweideten Kontrollflächen weitgehend konstant. In leguminosen- und krautreichen Flächen war die Reduzierung der oberirdischen Biomasse durch Rinder stärker als durch Schafe, während Beweidung mit Schafen in grasdominierten Flächen tendenziell zu einer stärkeren Biomassereduktion führten. Im Vergleich $\mathrm{zu}$ der oberirdischen Biomasse wurde der oberirdische Stickstoffvorrat weniger stark reduziert, da das $\mathrm{C} / \mathrm{N}-$ Verhältnis der Biomasse durch Beweidung verringert wurde.

Das GrassMan Projekt wird in einer Matrix von Wiesenplots auf historisch altem Grünland durchgeführt. Die Bewirtschaftungsintensität unterscheidet sich bezüglich der Düngung (keine vs. NPK-Düngung) und der Schnittfrequenz (ein vs. drei Schnitte pro Wachstumsperiode). Zusätzlich wurde durch gezielten Herbizideinsatz gegen entweder Monokotylen oder Dikotylen ein Gradient in der Pflanzenartenzahl erzeugt.

Wir haben den Einfluss von Pflanzendiversität und Bewirtschaftungsintensität auf die oberirdische- und unterirdische Biomasse und die oberirdische Produktion im Jahr 2009 untersucht. Während Düngung zu einer starken Steigerung der oberirdischen Biomasse und Biomasseproduktion führte, hatte eine erhöhte Schnittfrequenz nur eine leichte Steigerung der Produktion zur Folge. Höhere Artenvielfalt ging mit einer leichten Abnahme der 
Biomasseproduktion einher und hatte keinen signifikanten Einfluss auf die stehende ober- und unterirdische Biomasse am Ende der Wachstumsperiode. Das Wurzelsystem war weitgehend unbeeinflusst von der Düngung und wurde durch häufigen Schnitt leicht reduziert. Es konnte keinen Hinweis auf unterirdische komplementäre Ressourcennutzung festgestellt werden.

Des Weiteren wurden auf der GrassMan Fläche Untersuchungen zum Wasserhaushalt in Abhängigkeit der Bewirtschaftungsintensität durchgeführt. Dabei wurden mit Hilfe von Wägelysimetern sowohl die Evapotranspiration als auch die Tiefensickerung und Grundwasserneubildung während der Wachstumsperiode 2009 erfasst. Die Untersuchungen ergaben, dass NPK-Düngung zu einer Steigerung der Biomasseproduktion um 50-70\% und einer Steigerung der Evapotranspiration von 10-15\% und somit zu einer Steigerung der Wasserausnutzungseffizienz um 20 - 30 \% führte. Damit einher ging eine Verringerung der Tiefensickerung um $50 \%$. Die Schnitthäufigkeit hatte keinen Einfluss auf den Wasserhaushalt der untersuchten Fläche. Sowohl Evapotranspiration als auch Infiltration hingen stark von der oberirdischen Biomasseproduktion ab.

Der letzte Schwerpunkt unserer Untersuchungen befasste sich mit den Auswirkungen von Management auf funktionelle Blatteigenschaften von acht Grünlandarten auf der GrassMan Fläche in den Jahren 2009 und 2010. Es wurden sowohl die spezifische Blattfläche als auch die massen- und oberflächenbezogenen Stickstoffkonzentrationen von acht Graslandarten erfasst. Wir konnten zeigen, dass NPK-Düngung bei allen Arten zu einer starken Zunahme der drei Parameter führte, während die Auswirkung verschiedener Schnittfrequenzen stark von der Ökologie einzelner Arten abhing. Eine Trockenperiode, gefolgt von starken Niederschlägen im Jahr 2010, führte zu erhöhten Werten im Vergleich zum Jahr 2009. Unterschiedliche Reaktionen der verschiedenen Arten auf die Bewirtschaftungsintensität führten sowohl zu Änderungen der blatteigenschaftsbasierten Rangfolge der Arten als auch der Beziehungen zwischen der spezifischen Blattfläche und der massen- bzw. oberflächenbezogenen Stickstoffkonzentration. Unsere Ergebnisse zeigen, dass funktionelle Blatteigenschaften weniger konstant gegenüber Landnutzung und klimatischen Bedingungen sind als bislang angenommen. 

CHAPTER 8

Appendix 


\subsection{Index of figures}

Figure 1.1: Location of the two experimental sites at the Solling Mountains, Central Germany. 17

Figure 1.2: Experimental design of the BIOMIX project. 18

Figure 1.3: Experimental design of the GrassMan project. 19

Figure 2.1: Aboveground and belowground biomass of the grazed and ungrazed control plots. 37

Figure 2.2: Aboveground and belowground nitrogen pools of the grazed and ungrazed control plots. 40

Figure 3.1: Small-scale species richness and relative abundance of functional groups in terms of biomass in the sampled subplots $\left(0.25 \mathrm{~m}^{-2}\right)$ in the three diversity treatments. 55

Figure 3.2: Dependence of the aboveground biomass harvested on species richness in the four management treatments. $\quad 58$

Figure 3.3: Dependence of standing fine root biomass on species richness in the two different cutting treatments $\quad 58$

Figure 3.4: Dependence of root/shoot ratio on species richness in the two fertilizer treatments. $\quad 60$

Figure 3.5: Dependence of specific root length on species richness. 61

Figure 3.6: Dependence of root area index on species richness. 61

Figure 4.1: Mean daily evapotranspiration, VPD and global radiation, infiltration, and precipitation and volumetric soil water content in $0-10 \mathrm{~cm}$ soil depth in the four treatments over the whole measurement period.

Figure 4.2: Cumulative values of evapotranspiration and infiltration in the four treatments over the whole observation period.

Figure 4.3: Water use efficiency and aboveground biomass production in the four treatments during the whole measurement period.

Figure 4.4: Relation between aboveground biomass production and cumulative evapotranspiration or cumulative infiltration in the 24 study plots.

Figure 5.1: Relationship between specific leaf area and mass-based leaf $\mathrm{N}$ concentration of eight grassland species in June 2009 and August 2010 in the four management treatments.

Figure 5.2: Relationship between specific leaf area and area-based leaf $\mathrm{N}$ concentration of eight grassland species in June 2009 and August 2010 in the four management treatments.

Figure 8.1: Different swards at the BIOMIX site in spring 2008.

Figure 8.2: Sheep and cattle grazing at the BIOMIX site in spring 2008 . V

Figure 8.3: View of the GrassMan site in June 2009. VI

Figure 8.4: Construction of lysimeters as described in Chapter 4. VII

Figure 8.5: Weighing of lysimeters and lysimeter within the sward as described in Chapter $4 . \quad$ VII 


\section{Index of tables}

Table 2.1: Periods of livestock grazing in the plots of the blocks A, B and C in the summers 2007 and 2008.

Table 2.2: $\alpha$-diversity and vegetation cover of the grazed $(n=6)$ and ungrazed control $(n=9)$ plots in July 2008.

Table 2.3: Summary of ANOVA results on the effect of the variables 'functional group abundance',

'livestock type' and the interaction of both on 10 parameters of vegetation structure and composition.

Table 2.4: Percentage of above- and belowground biomass and biomass $\mathrm{N}$ pools of the grazed plots relative to the ungrazed control plots.

Table 3.1: Management procedures conducted at the experimental site in 2008 and 2009.

Table 3.2: Summary of simplified mixed effects models for all investigated parameters including herbicide treatment $(\mathrm{H})$, cutting frequency and fertilization as fixed effects in initial models. 56

Table 3.3: Summary of simplified mixed effects models for all investigated parameters including cutting frequency and fertilization as fixed effects and species richness as a covariate in initial models.

Table 3A.1: Climatic conditions between April and September 2009 at the GrassMan site.

Table 4.1: Management procedures conducted at the experimental site before (2008) and during the experiment (2009). 75

Table 4.2: Results of Spearman's rank correlation analyses of mean evapotranspiration and infiltration rates with different climatic parameters for the four different management treatments in the measurement period.

Table 4.3: ANOVA results on the influence of fertilization and cutting frequency on various hydrological and vegetation parameters.

Table 4.4: Water use efficiency of five of the most abundant species and mean of all five species in the 24 plots between June 27 and June 29.

Table 4.5: Biomass characteristics and plant species richness of the lysimeters in the four different treatments on 09.09.2009.

Table 5.1: Summary of general linear model results on the influence of cutting frequency (C), fertilization (NPK), species (Spec) and year (Y) and all possible interactions on specific leaf area (SLA) and mass- $\left(\mathrm{N}_{\text {mass }}\right)$ and area- $\left(\mathrm{N}_{\text {area }}\right)$ based foliar $\mathrm{N}$ concentrations.

Table 5.2: Coefficients of the interspecific variation of the specific leaf area and mass-based and areabased $\mathrm{N}$ concentrations among the eight species in the four management treatments in the years 2009 and 2010. 
Table 5.3: Rankings of eight grassland species based on the leaf traits SLA, $\mathrm{N}_{\text {mass }}$ and $\mathrm{N}_{\text {area }}$ in the four management treatments in 2009 and 2010.

Table 5.4: Mean alteration (shift in steps) of SLA-, $\mathrm{N}_{\text {mass }}$ - and $\mathrm{N}_{\text {area }}$-based species ranks in the eight species caused by fertilization or cutting frequency.

Table 5A.1: Management procedures conducted at the experimental site, date of leaf sampling and agricultural yield in the study years 2009 and 2010.

Table 5A.2: Global radiation, precipitation and mean air temperature (mean 1960-1990, 2009 and 2010) at Silberborn, Solling Mountains (DWD, 1960-1990) and at the GrassMan site at $2 \mathrm{~m}$ height $(2009 / 2010)$.

Table 5A.4: Specific leaf area of eight grassland species in June 2009 and August 2010 grown under four different management treatments.

Table 5A.5: Mass-based foliar N concentration of eight grassland species in June 2009 and August 2010 grown under four different management treatments.

Table 5A.6: Area-based N concentration of eight grassland species in June 2009 and August 2010 grown under four different management treatments.

Table 5A.7: Biomass yields at the GrassMan site in the two study years.

Table 8.1: Management procedures conducted at the GrassMan site in the study years 2008, 2009 and 2010.

Table 8.2: Summary of relationships between the specific leaf area and the mass-based leaf $\mathrm{N}$ concentration of 8 grassland species described in Chapter 5 .

Table 8.3: Summary of relationships between the specific leaf area and the area-based leaf $\mathrm{N}$ concentration of 8 grassland species described in Chapter 5.

Table 8.4: General linear model results on the influence of cutting frequency, fertilization and the interaction of both on the specific leaf area of 8 grassland species described in Chapter 5.

Table 8.5: General linear model results on the influence of cutting frequency, fertilization and the interaction of both on the mass-based leaf nitrogen concentration of 8 grassland species described in Chapter 5.

Table 8.6: General linear model results on the influence of cutting frequency, fertilization and the interaction of both on the area-based leaf nitrogen concentration of 8 grassland species described in Chapter 5. 


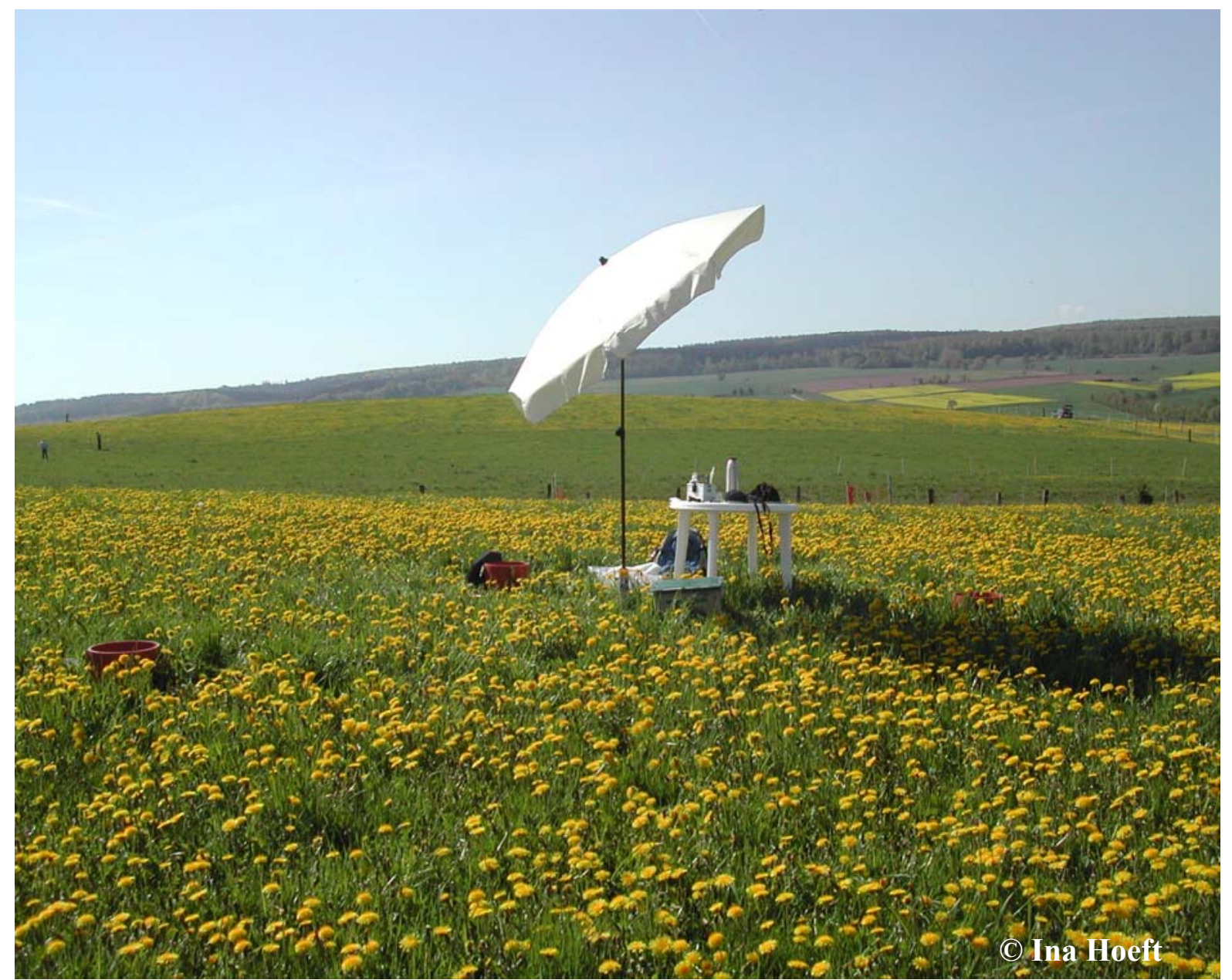

Figure 8.1: Different swards at the BIOMIX site in spring 2008.
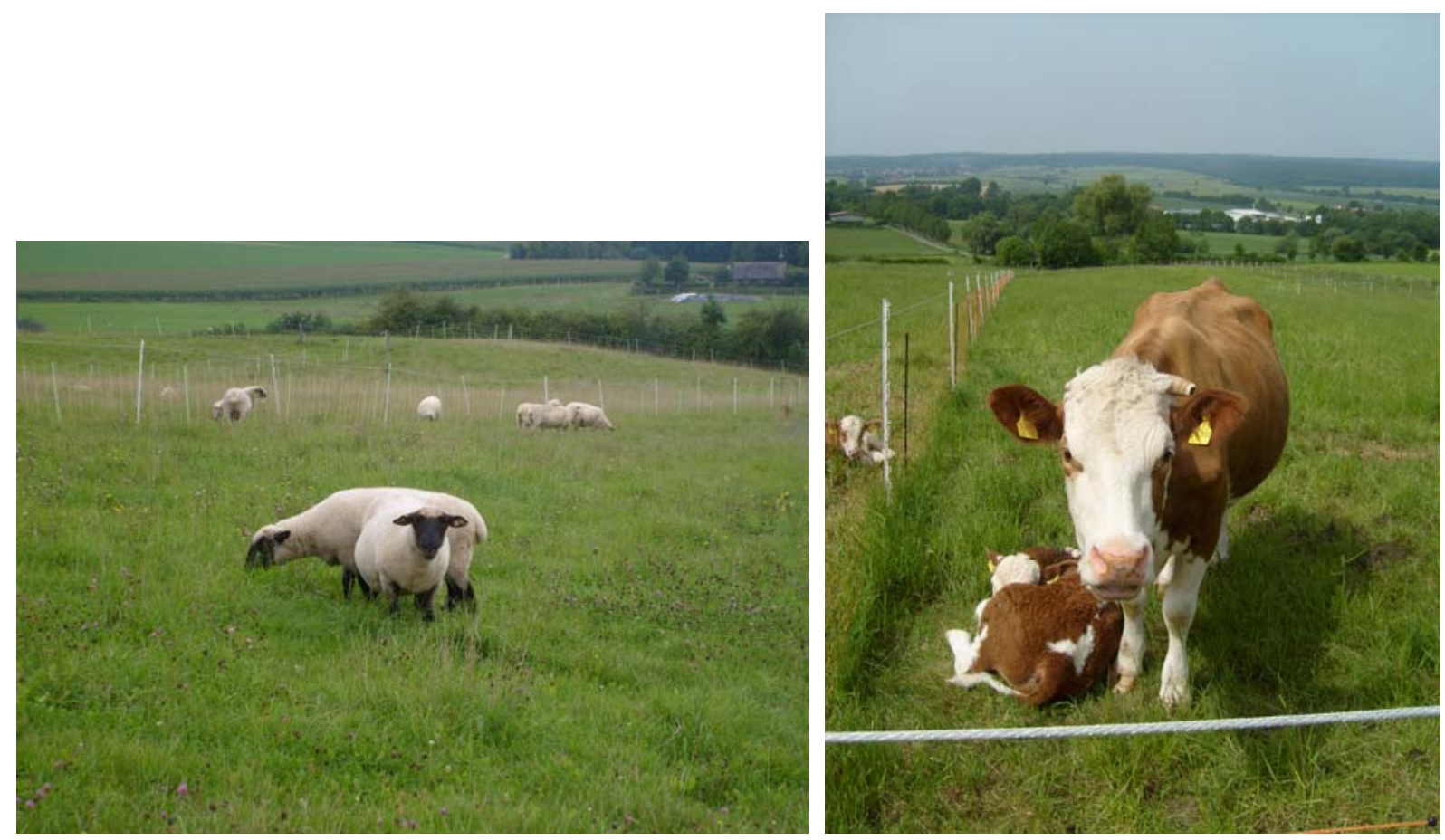

Figure 8.2: Sheep and cattle grazing at the BIOMIX site in spring 2008 . 

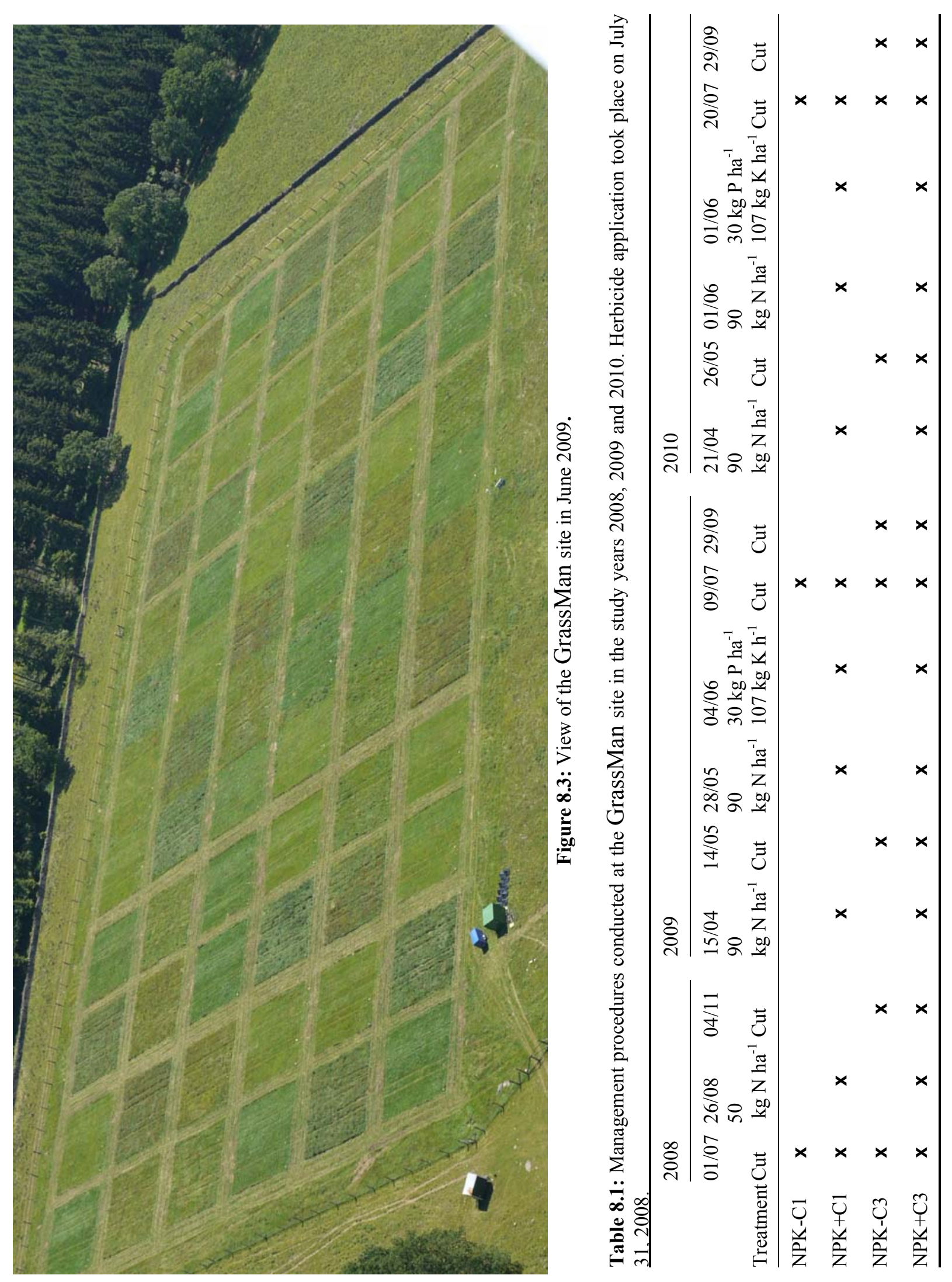


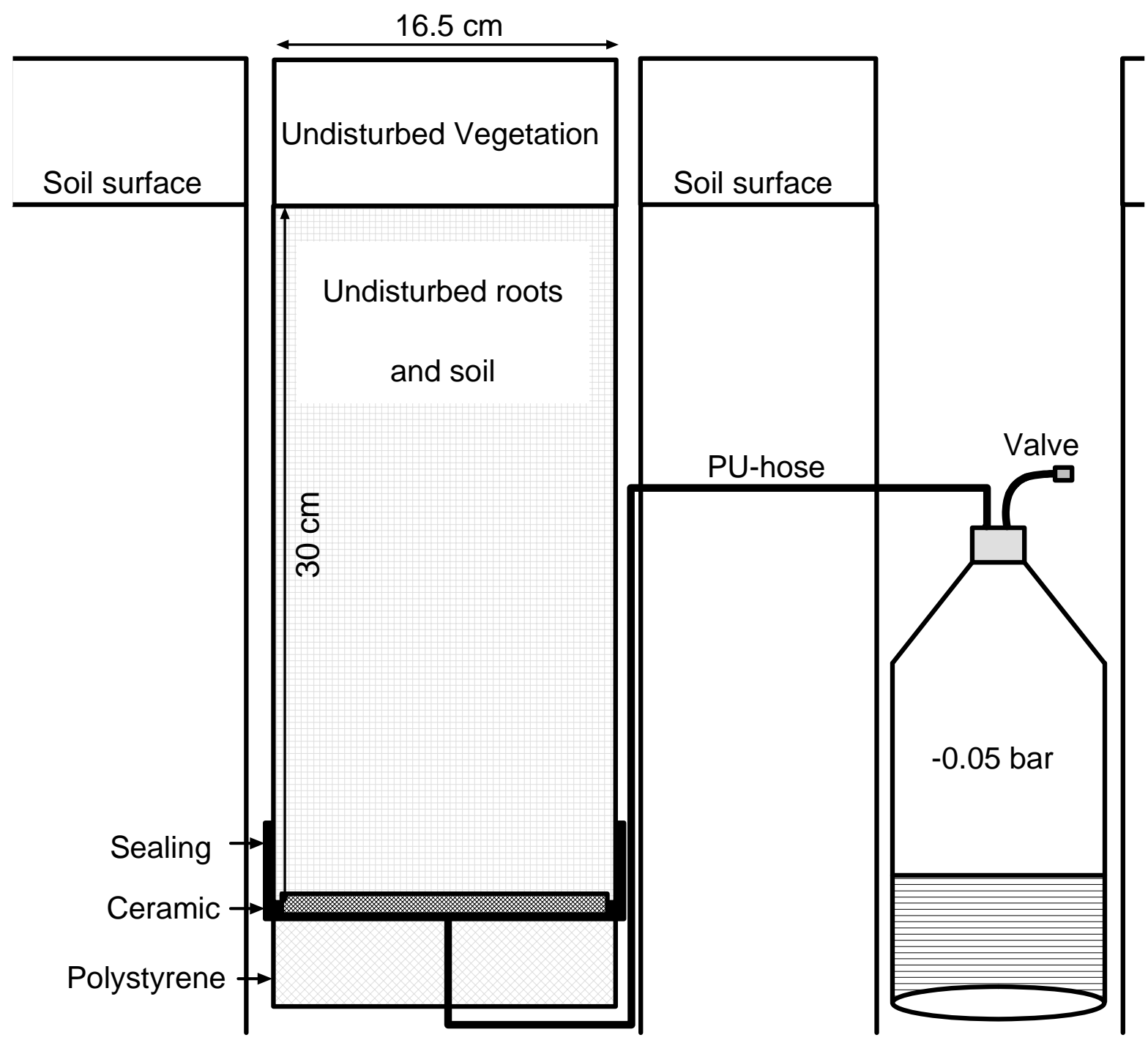

Figure 8.4: Construction of lysimeters as described in Chapter 4.

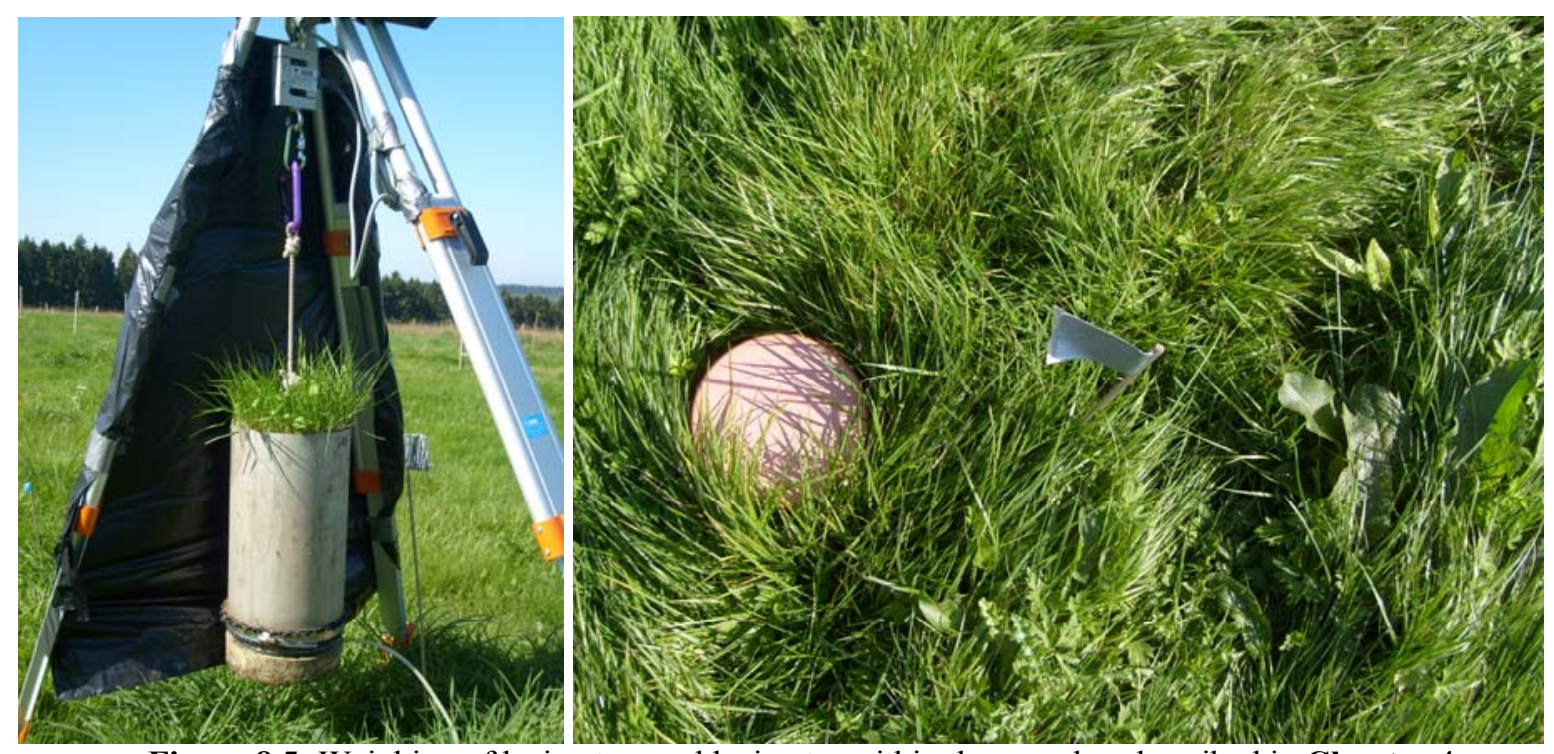

Figure 8.5: Weighing of lysimeters and lysimeter within the sward as described in Chapter 4. 


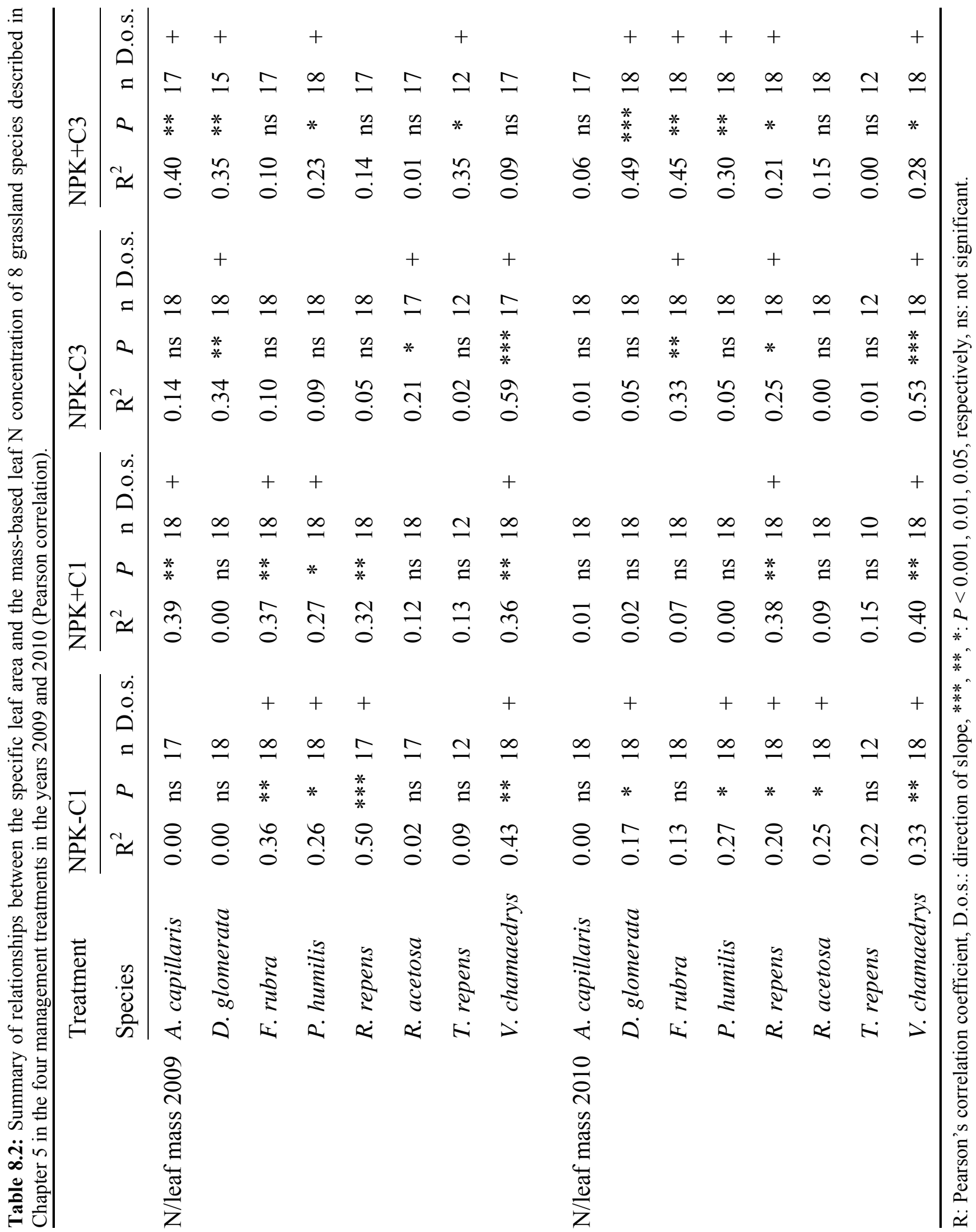




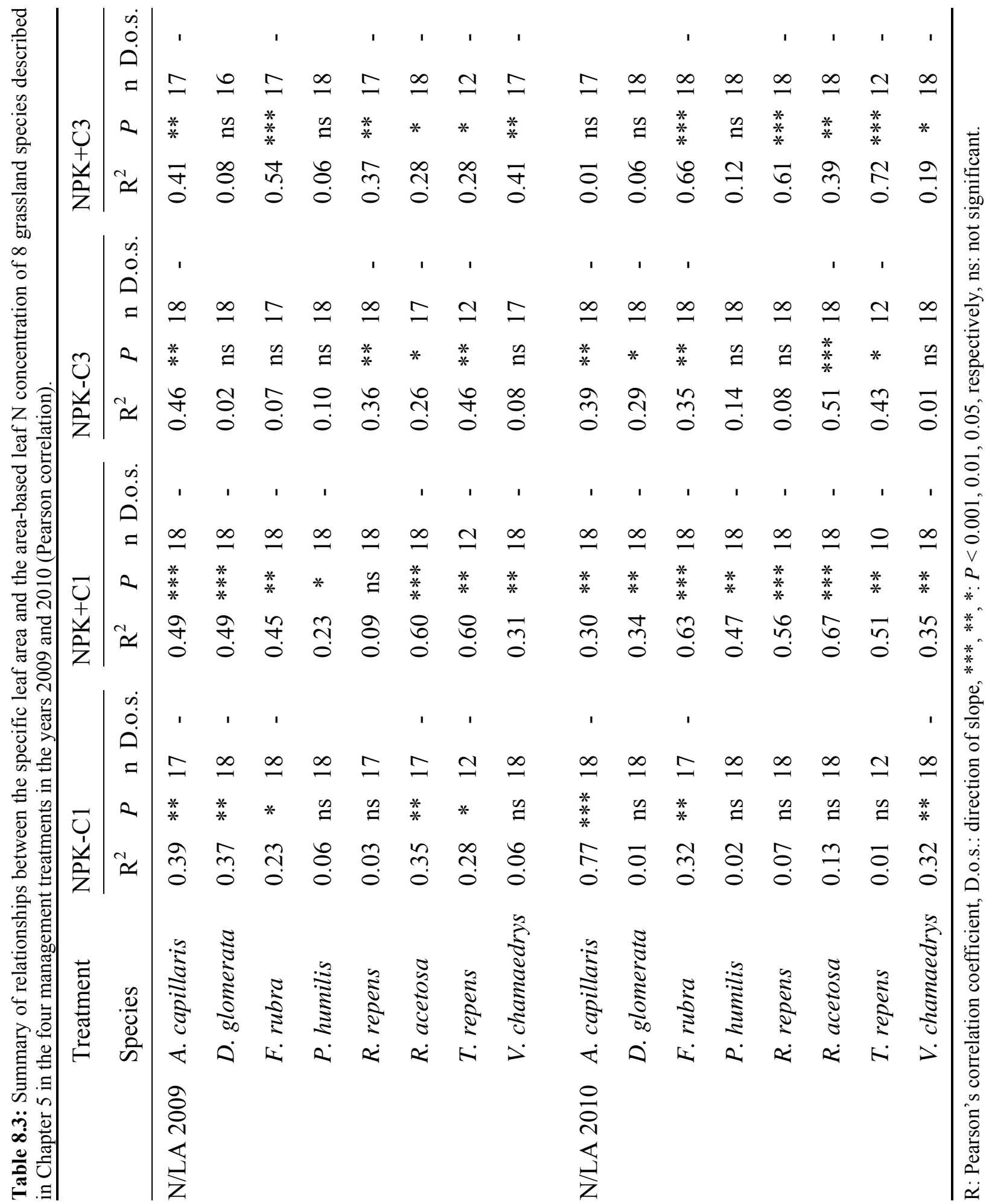




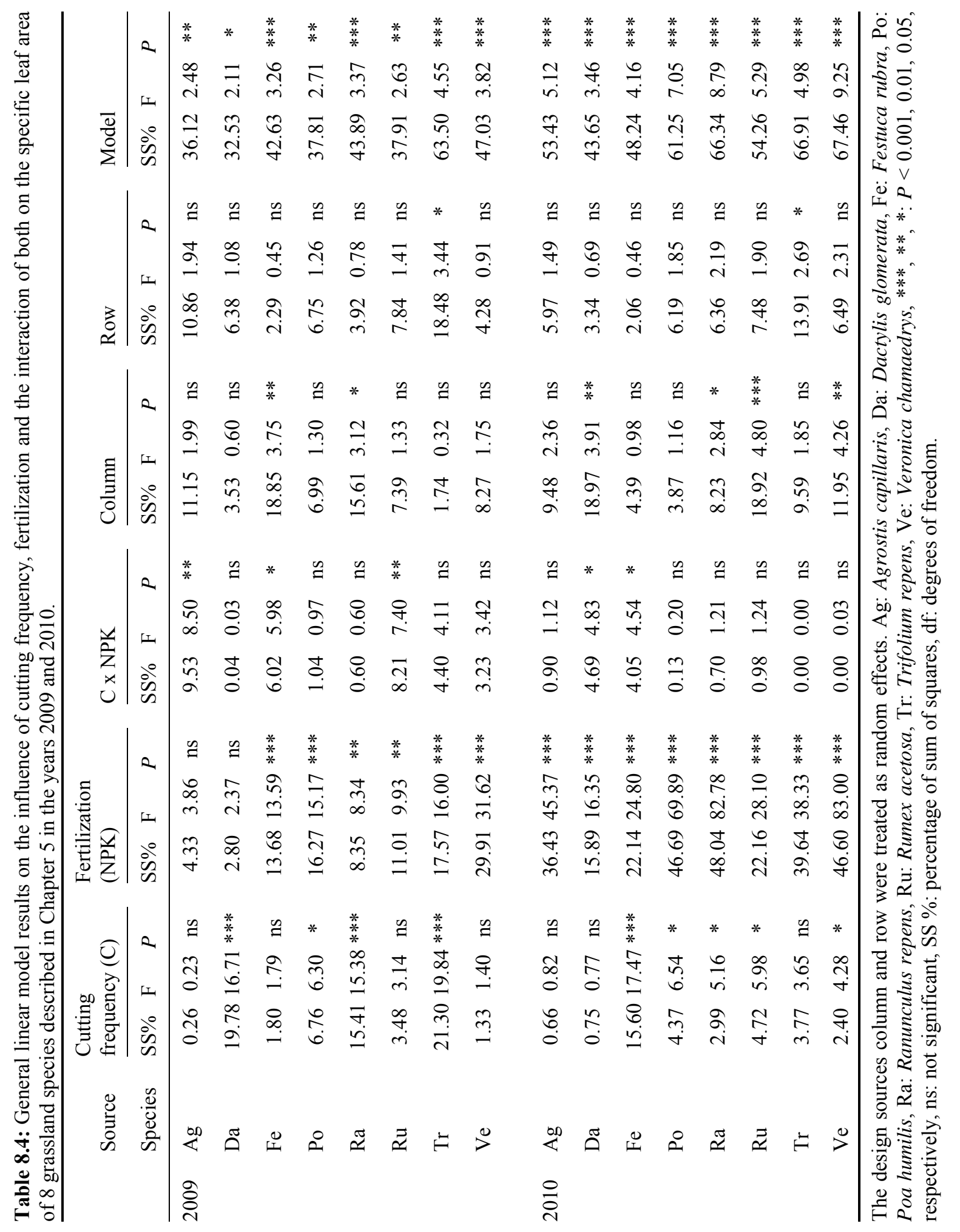




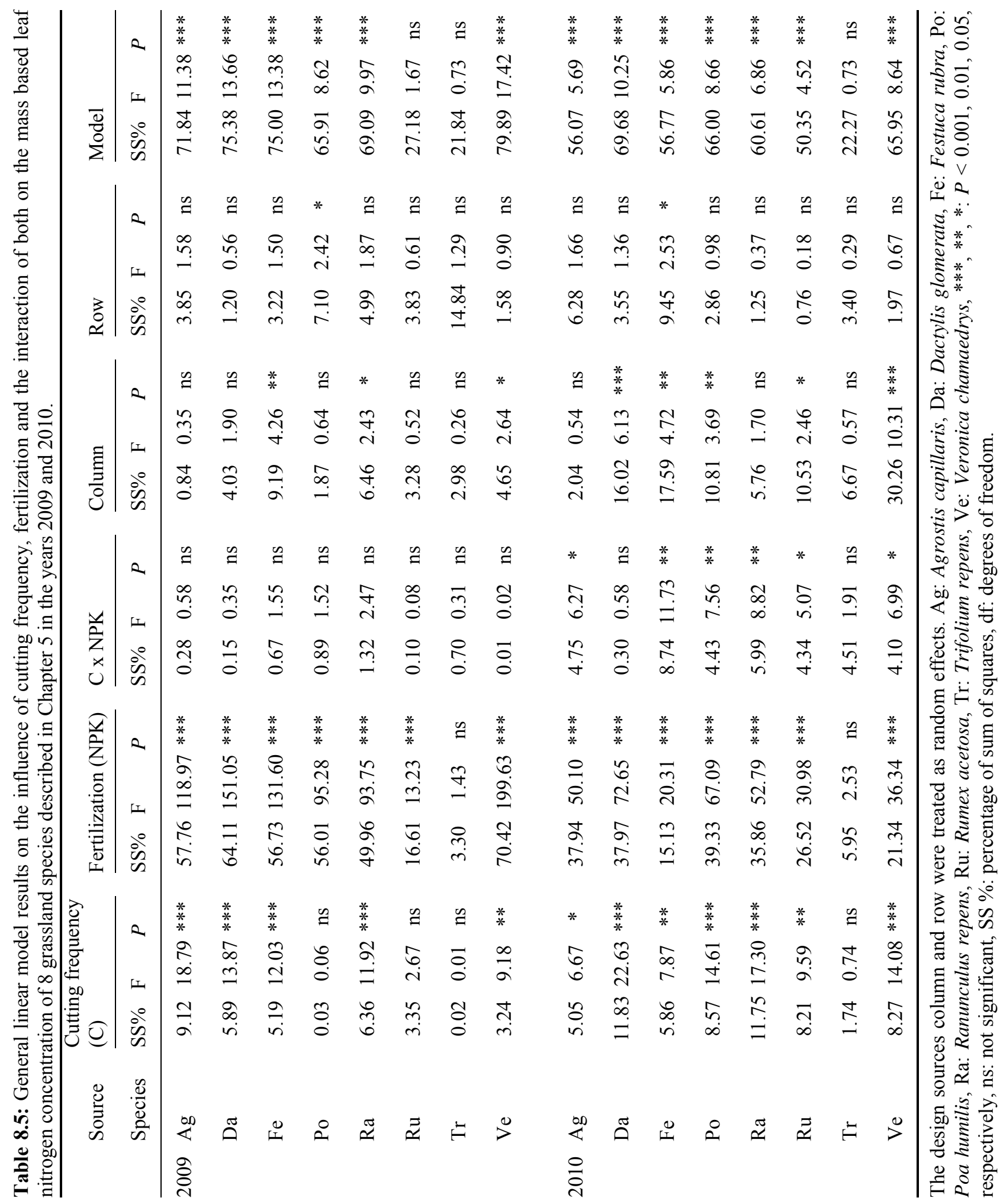




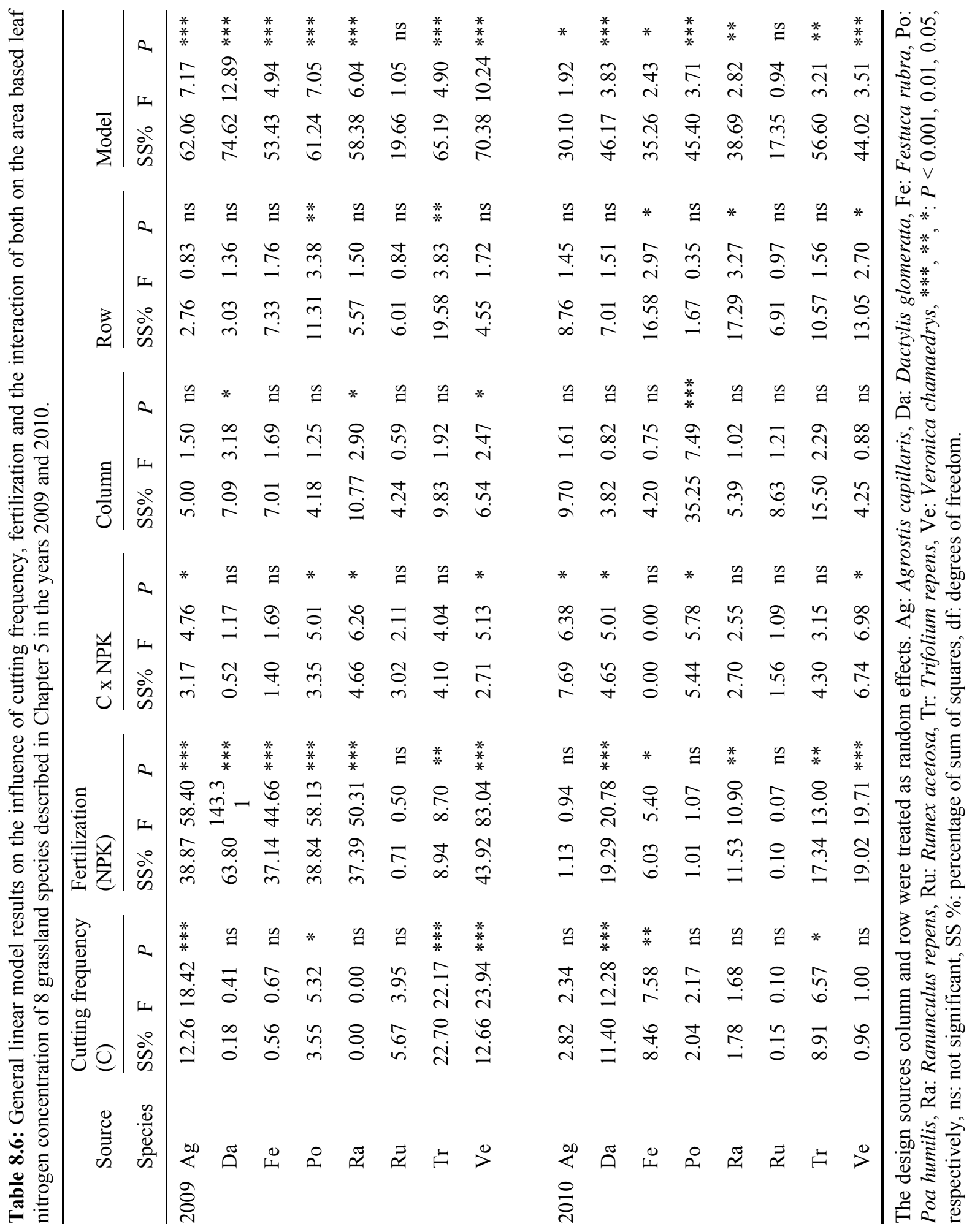



Many people have accompanied me during the last three years, without whom I would not have finished this work in the way I did. First of all, I want to thank Professor Christoph Leuschner, who gave me the opportunity to independently work on my thesis and was open to my ideas, but always gave me very valuable advice when needed. I also want to thank Dr. Dietrich Hertel for very helpful discussions and especially for very fast decisions about staff, whenever I was no longer able to do everything by myself. Professor Johannes Isselstein did not only offer to co-examine my thesis, but also had an open ear to discuss questions and ideas during the last three years. Thank you.

This study is part of the Cluster of Excellence 'Functional Biodiversity Research', and I want to thank the Ministry of Science and Culture of Lower Saxony and the "Niedersächsisches Vorab" for financial support for my thesis. Within this framework, the most important people were my GrassMan companions: Lana Dobrint, Carola Feßel, Tatiana From, Ina Hoeft and Ute Petersen. It was fun!

Many people helped with the site installation and management and thereby created the frame for this work. Dr. Lars Köhler did a great job during site installation and in supervising site management. I also want to thank the staff of the experimental farm Relliehausen, the Department of Grassland science, and the experimental botanical garden.

I was not able to conduct all this work by myself and therefore I want to thank: Gabi \& Florian Hammes, Nicole Legner and Dr. Boris Rewald, for help in the field, Jutta Czernitzki, Irmgard Gerstmann, Marianne Gscheidlen, Uta Nüsse-Hahne, Ute Schlonsog, Mechthild Stange, and many student assistants, for help in processing samples, Heiko Eichner, Maximilian v. Fragstein and Constantin Braune for help during lysimeter installation, Dr. Heinz Coners for constant help with all kinds of technical problems and the supply with climatic data, PD Karsten Wesche and Dr. Christoph Scherber for statistical advice, Anne Vincent and Diana Rhudick for being my best reviewers and my father for the unique opportunity to get a view of the GrassMan site from a plane.

I want to thank Irmgard Gerstmann, Peter Hajek, Gabi Krisinger and Dr. Bernhard Schuldt for patiently sharing an office with me and all people at the Plant ecology department for giving me such a good time.

Special thanks go to my friends Bernhardt, Carolyn, Christine, Claudio, Gabi, Hilmar, Janna, Marthe, Max, Paul, Silke, and especially to Boris, to my brother and sisters Sebastian, Johanna and Philine, and to my flat mates Angela, Anna, Frieder, Sonja and Tilmann, who all have been a great support during the last years.

Finally, I want to thank my parents Barbara Temeschinko-Rose and Dr. Thomas Rose for giving me the opportunity to study, but even more for their faith, patience and for their love. 


\section{LAURA ROSE}

Personal details

Date of birth

May $28^{\text {th }}, 1983$

Place of birth

Tübingen, Germany

Nationality

German

\section{Education}

$2008-2011$

$\mathrm{PhD}$ candidate in Biodiversity and Ecology,

Plant Ecology, Univ. of Göttingen

$2002-2007$

Study of Biology, Univ. of Göttingen

Degree obtained: Dipl.-Biol. Univ.

$1995-2002$

Gymnasium Wildeshausen

High school graduation: Allgemeine Hochschulreife

Work experience

2010

Field assistant Tibetan Plateau, China, Plant Ecology,

Univ. of Göttingen

$2007-2008$

Graduate assistant, Plant Ecology, Univ. of Göttingen

2007

Field assistant Estación Científica San Francisco,

Ecuador, Plant Ecology, Univ. of Göttingen

$2006-2007$

Undergraduate assistant, Plant Ecology,

Univ. of Göttingen

$2004-2007$

Undergraduate assistant, Systematic Botany,

Univ. of Göttingen

$2002-2005$

Schachtschneider Stauden und Marketing, Neersted 
